\title{
INDICADORES DE DESEMPENHO PARA O BENEFICIAMENTO DE MADEIRA SERRADA EM EMPRESAS DE PEQUENO PORTE: UM ESTUDO DE CASO
}

Roselane Biangaman de Matos

\begin{abstract}
Dissertação apresentada à Escola Superior de Agricultura "Luiz de Queiroz", Universidade de São Paulo, para obtenção do título de Mestre em Recursos Florestais, com opção em: Tecnologia de Produtos Florestais.
\end{abstract}

P I R A C I C A B A

Estado de São Paulo - Brasil

Agosto - 2004 


\title{
INDICADORES DE DESEMPENHO PARA O BENEFICIAMENTO DE MADEIRA SERRADA EM EMPRESAS DE PEQUENO PORTE: UM ESTUDO DE CASO
}

\author{
Roselane Biangaman de Matos \\ Engenheiro Florestal
}

Orientador: Prof. Dr. MARCOS MILAN

Dissertação apresentada à Escola Superior de Agricultura “Luiz de Queiroz”, Universidade de São Paulo, para obtenção do título de Recursos Florestais, com opção em: de Produtos Florestais.

P I R A C I C A B A

Estado de São Paulo - Brasil

Agosto - 2004 


\section{Dados Internacionais de Catalogação na Publicação (CIP) DIVISÃO DE BIBLIOTECA E DOCUMENTAÇÃO - ESALQ/USP}

Matos, Roselane Biangaman de Indicadores de desempenho para o beneficiamento de madeira serrada em empresas de pequeno porte: um estudo de caso / Roselane Biangaman de Matos. - - Piracicaba, 2004. $100 \mathrm{p}$.

Dissertação (mestrado) - - Escola Superior de Agricultura Luiz de Queiroz, 2004. Bibliografia.

1. Indicadores de produtividade 2. Indústria madeireira 3. Madeira serrada 4. Microempresa I. Título

CDD 674.2

\section{"Permitida a cópia total ou parcial deste documento, desde que citada a fonte - O autor"}


Aos meus pais, Rosa Biangaman de Matos

Miguel Antonio de Matos Que sempre me incentivaram a sempre seguir em frente para superar desafios. 


\section{AGRADECIMENTOS}

Ao Professor Marcos Milan (LER/ESALQ/USP) pela paciência, amizade, incentivo, apoio, oportunidade e principalmente por sempre ter acreditado em mim e a sua esposa Cora pela grande ajuda e atenção.

Ao Professor Gabriel Ádrian Sarriés (LCE/ ESALQ/USP) pelas sugestões de melhoria desse trabalho e por sempre me incentivar a trilhar novos caminhos e a sua esposa Silvana Vicino Sarriés pelo apoio e amizade.

Aos Professores Fernando Seixas (LCF/ESALQ/ USP), José Nivaldo Garcia (LCF/ESALQ/ USP) e Dário Henrique Alliprandini (DEP/UFSCAR) pela atenção e sugestões de melhoria para elaboração desse trabalho.

Ao Gilberto Carlos Nascimento, Hildemar Martin e Hamilton Martin Júnior pelo suporte e pela oportunidade de desenvolver esse trabalho na Martin Esquadrias de Madeira.

Ao André Luiz Watanabe por ter compartilhado comigo os momentos difíceis, pelo apoio e amizade. 
Aos amigos Juventino Bicudo Filho, Lígia Aíra de Medeiros, Celso B. Zacaria, Ligiana (BE/ESALQ/USP) e Dona Lourdes (LER/ESALQ/USP) pela ajuda, carinho, atenção e apoio.

Ao Conselho Nacional de Desenvolvimento Científico e Tecnológico (CNPq) pelo suporte financeiro.

A todas as pessoas que direta ou indiretamente contribuíram para a elaboração desse trabalho. 


\section{SUMÁRIO}

Página

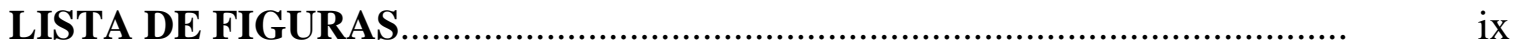

LISTA DE TABELAS ......................................................................

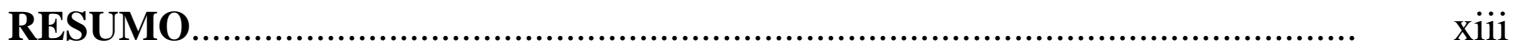

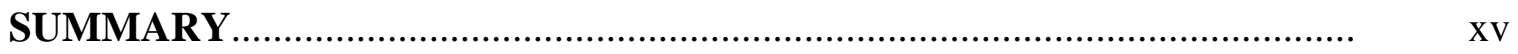

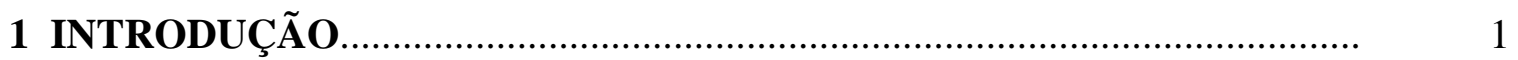

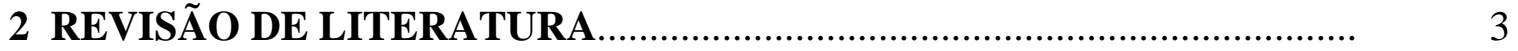

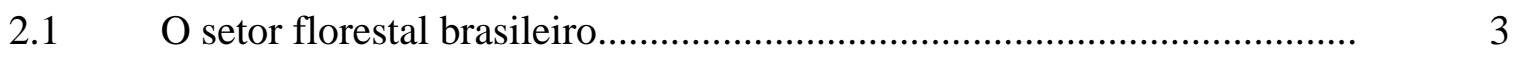

2.2 As micro, pequenas e médias empresas............................................... 9

$2.3 \quad$ A qualidade e suas dimensões............................................................... 15

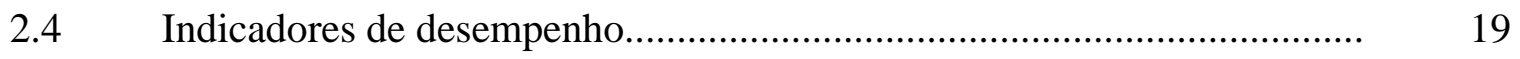

2.4.1 Evolução dos sistemas de medição............................................................ 25

2.4.2 Desenvolvimento de indicadores de desempenho.................................. 28

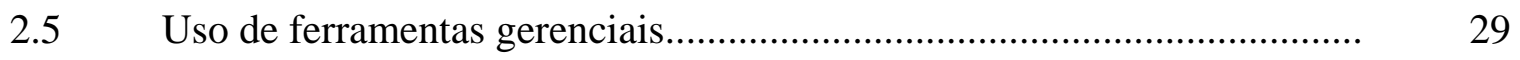

2.5.1 FMEA - Failure mode and effect analysis......................... 31

2.5.2 Diagrama de Ishikawa....................................................................... 33

3 MATERIAL E MÉTODOS..................................................................... 36

3.1 Caracterização da empresa do estudo de caso.......................................... 36

3.2 Desenvolvimento de indicadores referentes ao processo produtivo.......... 37

3.2.1 Fluxogramas da empresa e do processo produtivo................................... 37

3.2.2 Pontos críticos do processo................................................................ 38

3.2.3 Definição dos potenciais críticos de falha............................................... 39

3.2.4 Estudo das causas dos pontos críticos.................................................. 41 
3.2.5 Medidas de desempenho......................................................................... 42

4 RESULTADOS E DISCUSSÃO..................................................................

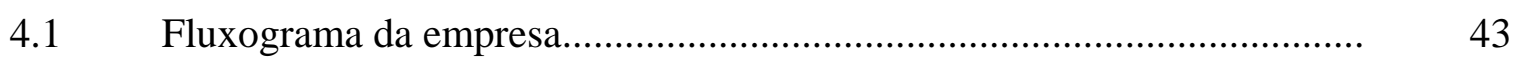

4.2 Fluxograma do processo produtivo........................................................... 45

$4.3 \quad$ Pontos críticos do processo...................................................................... 49

4.4 Definição dos potenciais críticos de falha.................................................... 50

4.5 Estudo das causas dos pontos críticos....................................................... 57

4.5.1 Secagem e armazenagem de madeira....................................................... 57

4.5.1.1 Perda de madeira no processo de secagem e armazenagem...................... 57

4.5.1.2 Quantidade de madeira descartada na secagem e armazenagem................ 59

4.5.1.3 Madeira exposta ao tempo na secagem e armazenagem............................. 61

4.5.2 Pré-corte de batente e caixilho....................................................................... 63

4.5.2.1 Sobras de madeira no pré-corte de batente e caixilho................................... 63

4.5.2.2 Presença de defeitos no pré-corte de batente e caixilho............................... 64

4.5.3 Beneficiamento.................................................................................. 65

4.5.3.1 Seleção de madeira no beneficiamento....................................................... 65

4.5.3.2 Montantes fora de esquadro no beneficiamento.......................................... 66

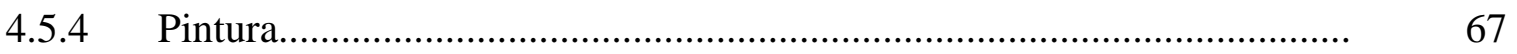

4.5.4.1 Agilidade e espaço disponível para pintura................................................. 68

4.5.5 Montagem........................................................................................... 69

4.5.5.1 Rachaduras na montagem........................................................................ 69

4.5.5.2 Aparecimento de frestas durante a montagem............................................ 69

4.5.5.3 Qualidade do lixamento das peças na montagem........................................ 70

4.5.5.4 Aparecimento de peças tortas na montagem............................................... 71

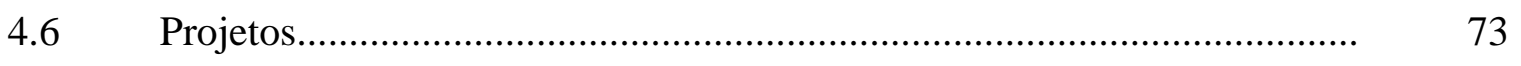

4.7 Medidas de desempenho......................................................................... 73

4.7.1 Secagem e armazenagem de madeira.....................................................

4.7.2 Pré-corte de batente e caixilho.................................................................

4.7.3 Beneficiamento.................................................................................. 


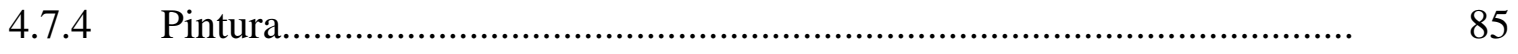

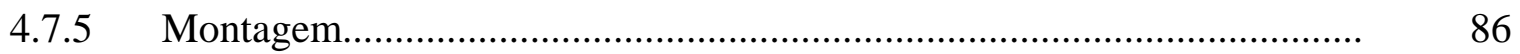

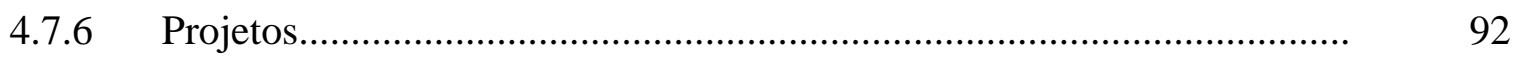

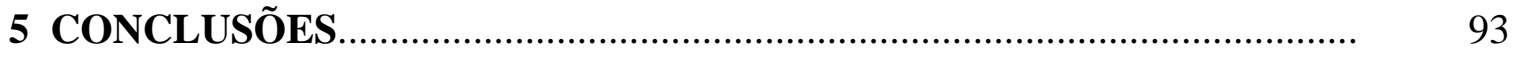

REFERÊNCIAS BIBLIOGRÁFICAS...................................................... 94 


\section{LISTA DE FIGURAS}

1 Superfície terrestre e florestal (milhões de hectares) de cada região................................................................................................... 4

2 Cadeia produtiva da madeira................................................................. 5

3 Produção de serrados no Brasil durante a década de 90 ................................ 6

4 Empresas exportadoras de produtos a base de madeira e

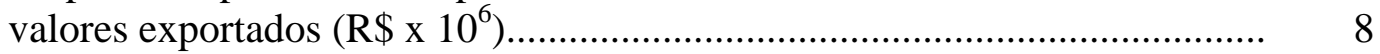

5 Geração de postos de trabalho pelas micro e pequenas empresas nacionais no setor de comércio e serviços em

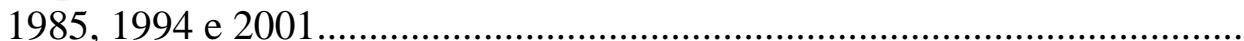

6 Geração de postos de trabalho pelas médias e grandes empresas nacionais no setor de comércio e serviços

7 Dimensões da qualidade total

8 Processo de gestão de desempenho e a posição do sistema de informação.

9 Os quatro passos do processo de gestão.

10 Diagrama de Ishikawa

11 Ciclo PDCA, suas fases e objetivos.......................................................... 35

12 Interação entre os processos da empresa....................................................... 43

13 Fluxograma do processo produtivo........................................................... 46

14 Diagrama de Ishikawa para perda de madeira na atividade de secagem e armazenagem de madeira.

15 Diagrama de Ishikawa para grande quantidade de madeira descartada na secagem e armazenagem..

16 Diagrama de Ishikawa para madeira exposta ao tempo sem uso de tabiques na armazenagem 
17 Diagrama de Ishikawa para sobra de madeira curta na atividade de pré- corte.

18 Diagrama de Ishikawa para presença de defeitos na madeira durante pré-corte.

19 Diagrama de Ishikawa para seleção da madeira durante o beneficiamento.

20 Diagrama de Ishikawa para montantes fora de esquadro durante o beneficiamento

21 Diagrama de Ishikawa para falta de agilidade no processo de pintura.

22 Diagrama de Ishikawa para o encaixe de peças no processo de montagem

23 Diagrama de Ishikawa para precisão no lixamento de peças

24 Diagrama de Ishikawa para peças fora de esquadro na montagem.

25 Indicadores de análise do fornecedor de madeira

26 Indicadores do gerenciamento do pátio de madeira.... 76

27 Volume de madeira $\left(\mathrm{m}^{3}\right)$ em estoque por espécie

28 Padronização da rotina para o processo de secagem.

29 Indicadores para quantificar o uso de madeira durante a atividade de pré-corte.

30 Aproveitamento da madeira de freijó.

31 Ocorrência de defeitos na madeira de freijó

32 Aproveitamento da madeira de cedro

33 Ocorrência de defeitos na madeira de cedro

34 Aproveitamento da madeira de tamarindo.

35 Ocorrência de defeitos na madeira de tamarindo

36 Gerenciamento da rotina para a atividade de beneficiamento de madeira. 
37 Gerenciamento da rotina para a atividade de

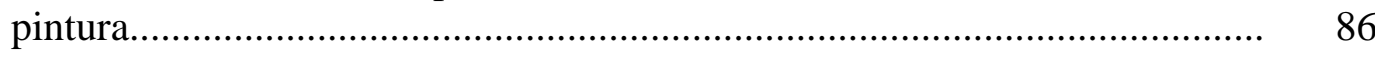

38 Indicadores para o processo de montagem............................................... 87

39 Peças rachadas (junho 2002 a abril de 2003)............................................. 88

40 Erros de projeto (junho 2002 a abril de 2003)........................................ 89

41 Erros de operador (junho 2002 a abril de 2003)......................................... 89

42 Erros de regulagem de máquina (junho 2002 a abril de 2003)

43 Retrabalho de janeiro a dezembro de 2002 ................................................. 91

44 Retrabalho de janeiro a dezembro de 2003............................................... 91 


\section{LISTA DE TABELAS}

Página

1 Valor exportado (US\$ milhões) segundo tamanho das empresas brasileiras 14

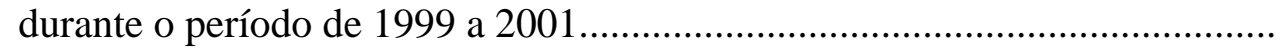

2 Índices e critérios de avaliação para o índice de ocorrência......................... 39

3 Índices e critérios de avaliação para o índice de severidade......................... 40

4 Índices e critérios de avaliação para o índice de detecção............................ 41

5 Pontos críticos do processo produtivo....................................................... 49

6 Aplicação do FMEA.......................................................................... 50

7 Avaliação geral dos fornecedores......................................................... 75

8 Avaliação da madeira empilhada no pátio.............................................. 78 


\section{INDICADORES DE DESEMPENHO PARA O BENEFICIAMENTO DE MADEIRA SERRADA EM EMPRESAS DE PEQUENO PORTE: UM ESTUDO DE CASO}

Autora: ROSELANE BIANGAMAN DE MATOS

Orientador: Prof. MARCOS MILAN

\section{RESUMO}

Fatores como a carência tecnológica, contratação de mão de obra pouco qualificada, estrutura produtiva precária, necessidade crescente de adaptação à mudanças constantes de mercado e às novas regras estabelecidas pela economia global. Ressaltam a necessidade de utilização de técnicas que forneçam informações para serem utilizadas como base para o gerenciamento das pequenas e médias empresas. Essas informações servem como fundamento para o processo de tomada de decisão. E os indicadores de desempenho surgem como uma oportunidade de melhoria que impulsiona a organização para o desenvolvimento tecnológico e para o auto gerenciamento dentro dos níveis operacional (chão de fábrica na produção), tático (supervisores) e estratégico (diretores, 
gerentes). O objetivo deste trabalho foi desenvolver indicadores de desempenho para a atividade de beneficiamento de madeira em uma empresa de pequeno porte. Para tanto, o desenvolvimetno foi realizado inicialmente com a elaboração de fluxogramas dos processos (macro) executados pela empresa e do processo produtivo, que é o principal foco desse trabalho. A partir dos fluxogramas, os pontos críticos do processo produtivo foram identificados utilizando a técnica "Brainstorming não estruturado". A seguir foi aplicada a técnica FMEA (failure mode and effect analysis) em cada ponto crítico, visando avaliar o impacto desses pontos no processo produtivo e para cada um elaborouse um estudo de causa utilizando Diagrama de Ishikawa. A partir do estudo da causa foram desenvolvidos indicadores de desempenho para atuar em pontos críticos. Os indicadores auxiliam a empresa durante o processo de tomada de decisões com base em fatos e dados, auxiliam o gerenciamento da rotina, sinalizam alterações no processo, apontam necessidades de treinamentos para a equipe, permitem a redução de erros e o desenvolvimento de oportunidades de melhoria. 


\title{
PERFORMANCE INDICATORS FOR SAWED WOODEN IMPROVEMENT IN SMALL ENTERPRISES: A CASE STUDY
}

\author{
Author: ROSELANE BIANGAMAN DE MATOS
}

Adviser: Prof. MARCOS MILAN

\section{SUMMARY}

Factors like the lack of technology, the hiring of a not very well quantified labor, a poor productive structure, an increasing necessity of adjustment to constant changes in the market and to new rules established by global economy, encourage the need for the use of techniques that supply information to be used as the base for the management of small and medium enterprises. These information are fundamental in the process of making decision. This way the performance indicators come up as an opportunity of improvement that drives the organization to words a technological development to the self - management in operational levels (the basic ground in production), tactical (supervisors) and strategical (directors, managers). This study aimed to develop performance indicators for sowed wood improvement in a small enterprise. Therefore, 
the development of performance indicators was firstly realized planning of with the fluxograms planning of the process that are executed by the enterprise (macro processes) and of the productive process, which is of this study the main points of this study. From the fluxograms, critical points of the productive process were identified by using the “not structured brainstorming” technique the FMEA (Failure Mode and Effect Analysis) technique, was applied in each critical point in order to valuate their impact in the productive process. A case study was planned for each point by using the Ishikawa Diagram. The performance indicators were developed based on the case study and it works on the critical points of productive process. These indicators help the enterprise during the process of taking decisions based on facts and data in the routine management, show the changes in the process, point out the needs on which the crew must be trained, allow the reduction of number of failures and develop opportunities. 


\section{INTRODUÇÃO}

A economia brasileira vem passando desde o início da década de 90 por um marcante processo de transformação, reformas econômicas e institucionais, para a adequação aos novos padrões de expansão da economia mundial. Mesmo com tantas inovações e dificuldades de adaptação à economia, o setor de base florestal brasileiro tem apresentado, neste período, índices crescentes e representativos na composição do produto interno bruto nacional (PIB), volume de exportações e geração de empregos diretos e indiretos.

A indústria florestal é composta pelos segmentos de polpa (pastas de alto rendimento e celulose), painéis (madeira sólida e reconstituídos), serrados e combustíveis (carvão e lenha). Juntos, esses setores são responsáveis por cerca de $4 \%$ do PIB nacional e até 2005 estão previstos US\$ 12 bilhões de investimentos nos setores de madeira serrada, móveis e papel. Deste montante, especificamente o setor de madeira serrada prevê investimentos de US\$ 5,4 bilhões, o que representa $45 \%$ do total a ser investido, e a força produtiva das indústrias de beneficiamento de madeira serrada é atribuída às empresas de pequeno porte. Das 10.000 unidades instaladas apenas 26\% correspondem à empresas de médio e grande porte. 
As pequenas empresas brasileiras possuem uma fundamental importância na geração de empregos, principalmente de mão de obra pouco qualificada, empregando cerca de 60,8\% da mão de obra ocupada no setor de prestação de serviços e comercial. A participação desse segmento na balança comercial vem se mostrando a cada ano mais significativa, sendo as micros, pequenas e médias empresas responsáveis por 30,2\% dos recursos exportados pelo Brasil. Esses índices poderiam ser maiores mas, são fortemente influenciados pela ausência de uma estrutura organizacional, falta de investimentos em tecnologia e inovação, dificuldade de acesso ao capital de giro e principalmente ausência de informações que permitam a aprendizagem e análise organizacional.

Considerando a importância sócio econômica das pequenas empresas do setor florestal, suas carências gerenciais e tecnológicas, a implantação de um sistema de informação gerencial surge como uma forte oportunidade de melhoria e aprendizagem organizacional que impulsiona a organização para o desenvolvimento tecnológico. Dessa forma, este trabalho teve como objetivo desenvolver indicadores de desempenho para empresas de pequeno porte de beneficiamento de madeira serrada. 


\section{REVISÃO DE LITERATURA}

\subsection{O setor florestal brasileiro}

A cobertura florestal mundial é de 3,9 bilhões de hectares, dos quais 47\% são florestas tropicais, 33\% boreais, 11\% temperadas e 9\% subtropicais (Juvenal \& Mattos, 2002). Dados levantados pela FAO (Food and Agriculture Organization of United Nations) em 2000 e apresentados por Carneiro (2003) indicam que as florestas nativas representam 30\% (3.870 milhões de hectares) da área florestal mundial (13.064 milhões de hectares) e desse montante a América do Sul possui 885.618 milhões de hectares de florestas nativas e o Brasil 549 milhões de hectares (Carneiro, 2003). A Figura 1 apresenta a superfície terrestre e a área florestal de cada continente em milhões de hectares. 


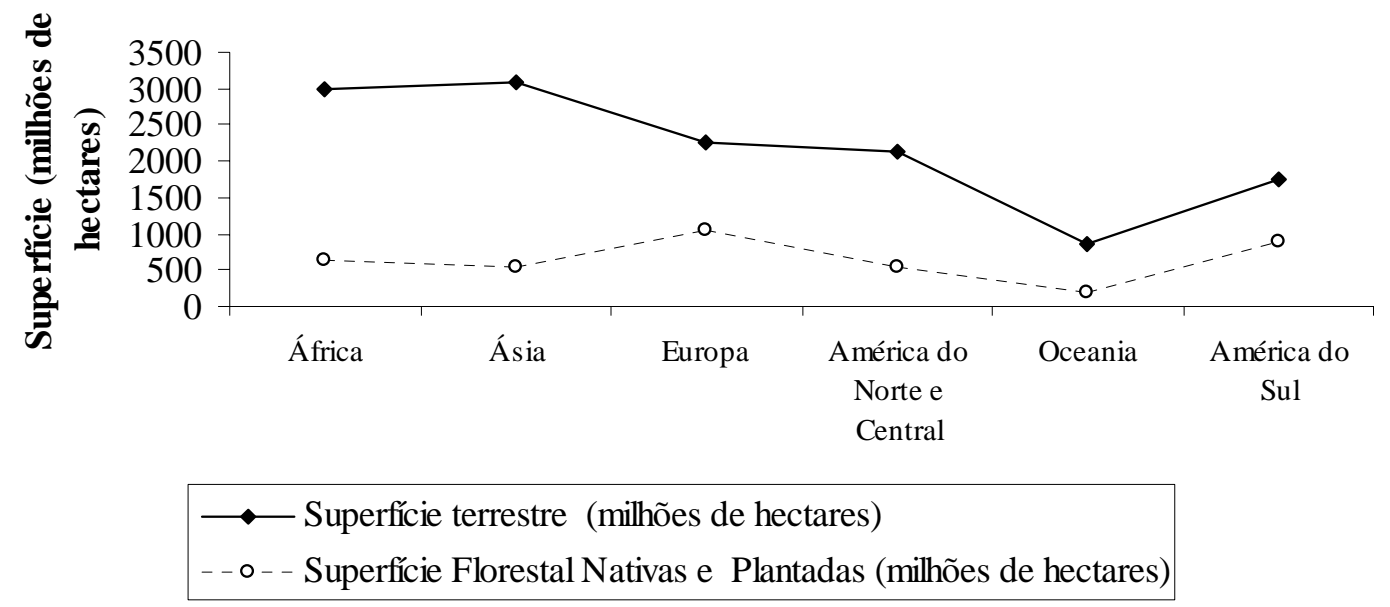

Figura 1 - Superfície terrestre e florestal de cada região terrestre (Carneiro, 2003)

O Brasil possui a segunda maior cobertura florestal do mundo, dos aproximadamente 886 milhões de hectares presentes no continente latino americano, $61 \%$ encontram-se no Brasil que caracteriza-se por apresentar excelentes condições edafoclimáticas para o desenvolvimento da silvicultura e avançado desenvolvimento tecnológico para exploração de florestas e transformação industrial da madeira (Juvenal \& Mattos, 2002 ). A cadeia produtiva da madeira representada na Figura 2, contempla a produção de madeira para energia, serrados, painéis e polpa para produção de papel e outras finalidades (Juvenal \& Mattos, 2002 ). 


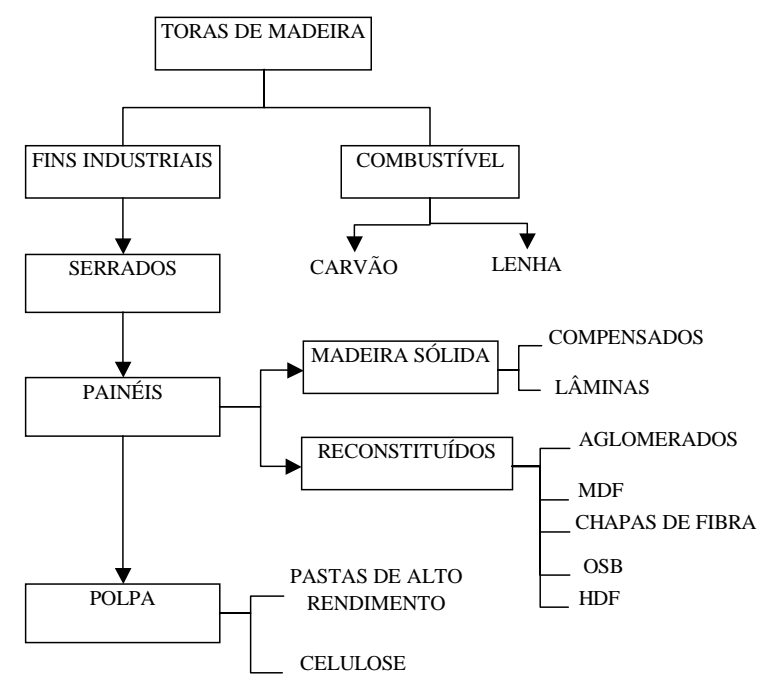

Figura 2 - Cadeia produtiva da madeira (Juvenal \& Mattos, 2002)

O consumo nacional de madeira serrada no Brasil sofreu um crescimento médio desde 1998, de 3,6\% ao ano e as aplicações da madeira serrada de folhosas e coníferas, que estão vinculadas a três segmentos básicos: a indústria moveleira, embalagens e construção civil (Oliveira, 2001). A Figura 3 ilustra este crescimento, com base nos dados fornecidos por STCP Engenharia de Projetos, Associação Brasileira da Indústria de Madeira Processada Mecanicamente (ABIMCI) e Associação Brasileira de Produtores de Madeira (ABPM). 


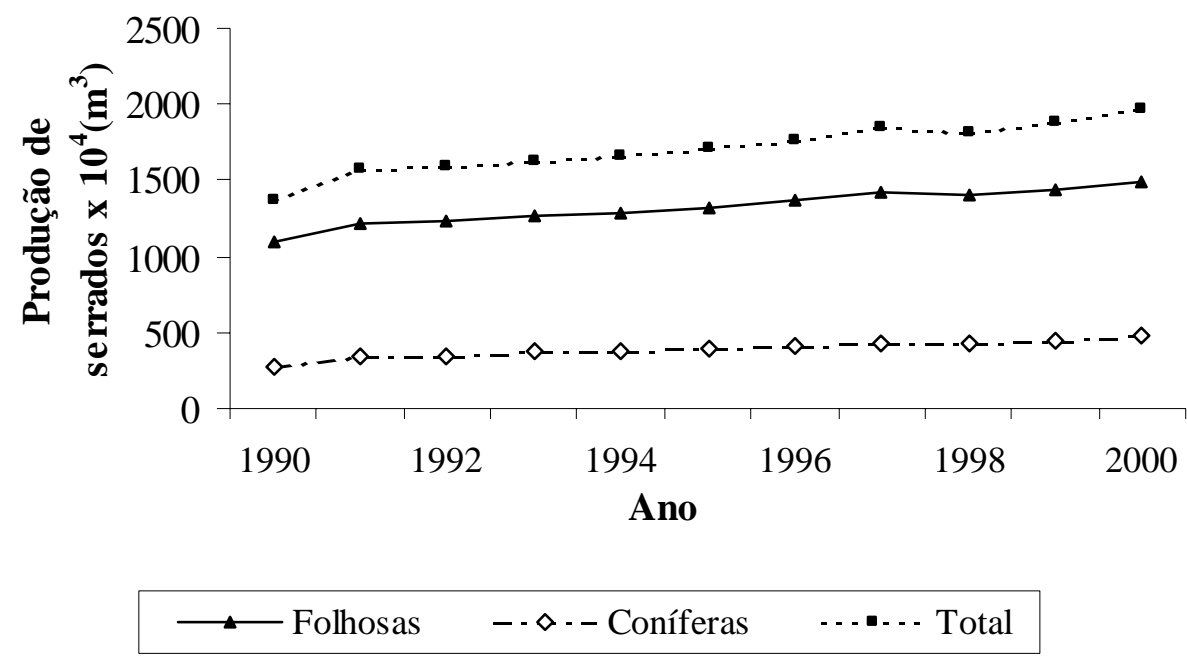

Figura 3 - Produção de serrados no Brasil durante a década de 90 (Remade, 2004)

O segmento de beneficiamento de madeira sólida é um grande gerador de empregos. Para cada um milhão de reais investidos na indústria de produtos de madeira sólida são gerados de 10 a 20 empregos, 01 para a indústria de celulose e papel, e para as indústrias automobilística e química esse valor investido não é suficiente para gerar um emprego. O setor florestal (madeira/móveis/papel) tem uma perspectiva de investimentos programados até 2005 da ordem de US\$ 12 bilhões. Especificamente, o setor de produtos de madeira sólida prevê investimentos da ordem de US\$ 5,4 bilhões até 2005, o que evidencia a perspectiva de crescimento do setor e revela sua importância para a economia brasileira e para a geração de empregos (Associação brasileira da indústria de madeira processada mecanicamente, 2004). 
O setor florestal brasileiro é de grande importância para a economia do país, quer seja na geração de empregos como para exportações. O volume exportado pelas indústrias de beneficiamento de madeira tem apresentado índices crescentes, na ordem de US\$ 913 milhões em 1998, atingindo US\$ 1,48 bilhão já no ano 2000 (Ministério do Meio Ambiente, 2004). Entre os principais consumidores dos bens produzidos pelo setor florestal, destacaram-se ao longo do ano 2000, a União Européia com 51 \%, os Estados Unidos com 23\% e o Mercosul com 18\% do volume exportado (Banco nacional de desenvolvimento econômico e social, 2003).

Como principais itens da pauta de exportação tem-se a madeira serrada e cortada com US\$ 519,5 milhões, a madeira compensada com US\$ 373,6 milhões, janelas, portas e armações com US\$ 169,1 milhões e a madeira perfilhada com US\$101,1 milhões. A Figura 4 apresenta dados do Banco Nacional de Desenvolvimento Social (Banco nacional de desenvolvimento econômico e social, 2003) quanto ao número de empresas que produzem produtos à base de madeira e os valores exportados de 1997 a 2001. 


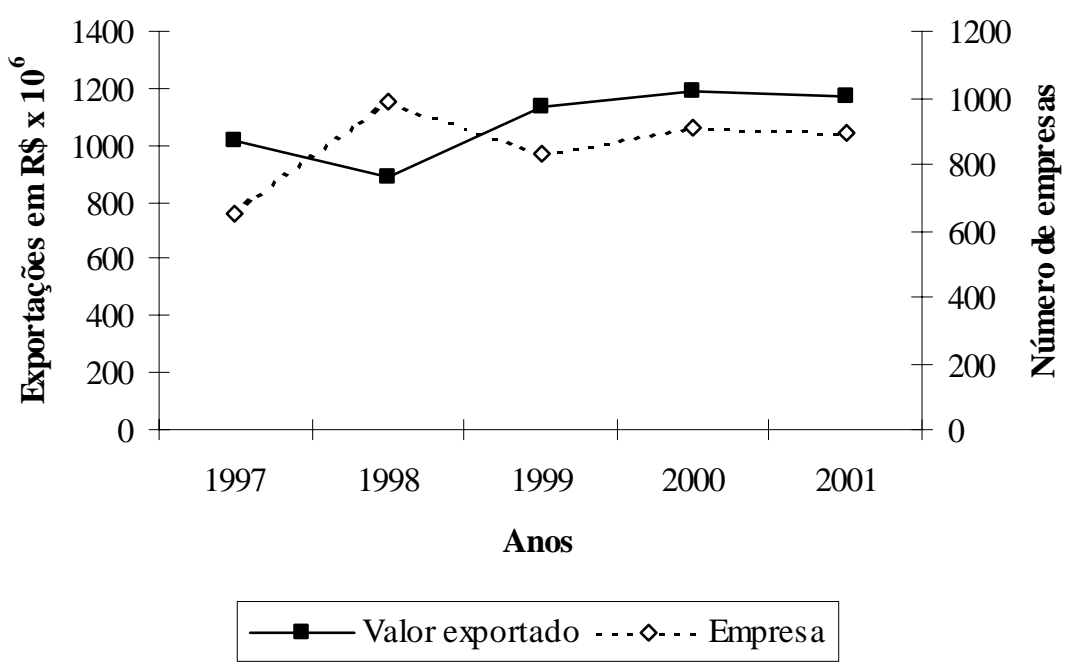

Figura 4 - Empresas exportadoras de produtos à base de madeira e valores exportados $(\mathrm{R} \$$ x 106) (Banco nacional de desenvolvimento econômico e social, 2003)

Segundo Nahuz (2004), o mercado mundial de madeira e produtos derivados é crescente, com exportação em torno de US\$ 98 bilhões/ano, deste montante 15\% são originários de países em desenvolvimento. Os produtos exportados são compostos tanto por produtos de pequena industrialização (madeira serrada) como por produtos de maior tecnologia agregada (painéis de madeira). No Brasil a produção de madeira serrada varia em torno de 19 a 22 milhões de $\mathrm{m}^{3} /$ ano.

No cenário macroeconômico brasileiro, o setor da indústria de base florestal tem mantido uma representatividade praticamente constante de participação na composição do PIB (Produto Interno Bruto) nacional nos últimos anos. O setor florestal apresenta taxas de crescimento positivas a partir do ano 2000 quando atingiu cerca de $2 \%$ do PIB 
(US\$ 12 bilhões), e desse montante, o setor madeireiro respondeu por US\$ 5,5 bilhões, enquanto que os US\$ 6,5 bilhões restantes pertencem aos setores de celulose, papel e papelão. No início de 2001 a indústria madeireira apresentou o terceiro maior índice de atividade em relação à capacidade produtiva instalada em comparação a outros setores da indústria de transformação, o que indica a busca pela consolidação dos mercados e aumento da produtividade (Associação brasileira de madeira processada mecanicamente, 2003)

O setor de produção de móveis e madeira serrada no Brasil é composto por 13.500 indústrias cadastradas. Dessas 10.000 são micro e pequenas empresas, as restantes são de médio - grande porte (Banco nacional de desenvolvimento econômico e social, 2003; Associação brasileira de madeira processada mecanicamente, 2003). Apesar do baixo grau tecnológico adotado pelas pequenas e médias empresas do setor de madeira serradas e móveis, o faturamento durante o período de 1999 a 2000 foi de US\$ 2,93 bilhões e registrou um incremento nas vendas de 30\% em relação ao ano de 1998 (Banco nacional de desenvolvimento econômico e social, 2003)

\subsection{As micro, pequenas e médias empresas}

Segundo a Lei n 9841 de 05/10/99 são consideradas microempresas, organizações que possuem valor de receita até US\$ 719,8 mil e empresas de pequeno porte com valor de receita de US\$ 719,8 mil a US\$ 3,5 milhões. O SEBRAE (Serviço 
Brasileiro de Apoio às Micro e Pequenas Empresas) classifica como microempresas, organizações que possuem até 9 pessoas ocupadas e microempresas com 10 a 49 pessoas ocupadas; este critério não leva em consideração as diferenças existentes entre processos produtivos distintos, uso intensivo de tecnologia de informação e/ou forte presença de mão de obra qualificada (Instituto Brasileiro de Geografia e Estatística, 2003). O BNDES (Banco Nacional de Desenvolvimento Econômico e Social) utiliza duas classificações de porte: uma segundo critérios determinados pelos países do Mercosul, para fins creditícios, e outra com base na receita operacional bruta anual. A classificação de porte para fins creditícios dos países do Mercosul considera as microempresas como organizações com valor de receita de até US\$ 400 mil e empresas de pequeno porte com valor de receita de US\$ 400 mil a US\$ 3,5 milhões (Instituto brasileiro degeografia e estatística, 2003).

A segunda classificação adotada pelo BNDES leva em consideração a receita operacional bruta anual e classifica como microempresas organizações que apresentam receita até US\$ 3,5 milhões. As empresas com receita superior a US\$ 3,5 milhões e inferior ou igual a US\$ 30,9 milhões são classificadas como pequenas, e as médias são as que apresentam receita entre US\$ 30,9 milhões e US\$ 177 milhões. Acima deste valor, encontram-se as grandes empresas (Banco nacional de desenvolvimento econômico e social, 2004).

Em estudos realizados em 2001, pelo Instituto Brasileiro de Geografia e Estatística (IBGE) e SEBRAE, as micros, pequenas e médias empresas brasileiras, 
apresentam como características: baixa intensidade de capital; altas taxas de abertura e fechamento de empresas em um curto espaço de tempo; forte presença de proprietários e membros da família como sócios e mão de obra ocupada nos negócios; poder decisório centralizado; estreito vínculo entre os proprietários e as empresas, não se distinguindo, principalmente em termos contábeis e financeiros a pessoa física da jurídica; utilização de mão de obra semi ou não qualificada com contratação direta; baixo investimento em inovação tecnológica; grande dificuldade de acesso ao financiamento de capital de giro e relação de complementariedade e subordinação com as empresas de grande porte (Instituto brasileiro de geografia e estatística, 2003).

Uma importante contribuição das micros e pequenas empresas ao crescimento e desenvolvimento do país é servirem como um amortecedor do desemprego. Constituem uma alternativa de ocupação para uma pequena parcela da população que tem condição de desenvolver seu próprio negócio sendo uma alternativa de emprego formal ou informal, para uma grande parcela da força de trabalho excedente, em geral com pouca qualificação, que não encontra emprego nas empresas de maior porte. Em 1985, as pequenas e micro empresas empregavam cerca de 3,5 milhões de pessoas, o que representava 50,7\% de toda mão de obra atuante no setor de comércio e serviços. A partir de 2001 houve um aumento significativo na geração de postos de trabalho, 7,3 milhões de pessoas, o que representa $60,8 \%$ da mão de obra ocupada neste setor. A Figura 5 ilustra a evolução da geração de empregos pelas micro e pequenas empresas de 1985 a 2001 e a Figura 6 mostra a desaceleração na geração de empregos pelas médias e 
grandes empresas no mesmo período (Instituto brasileiro de geografia e estatística, 2003).

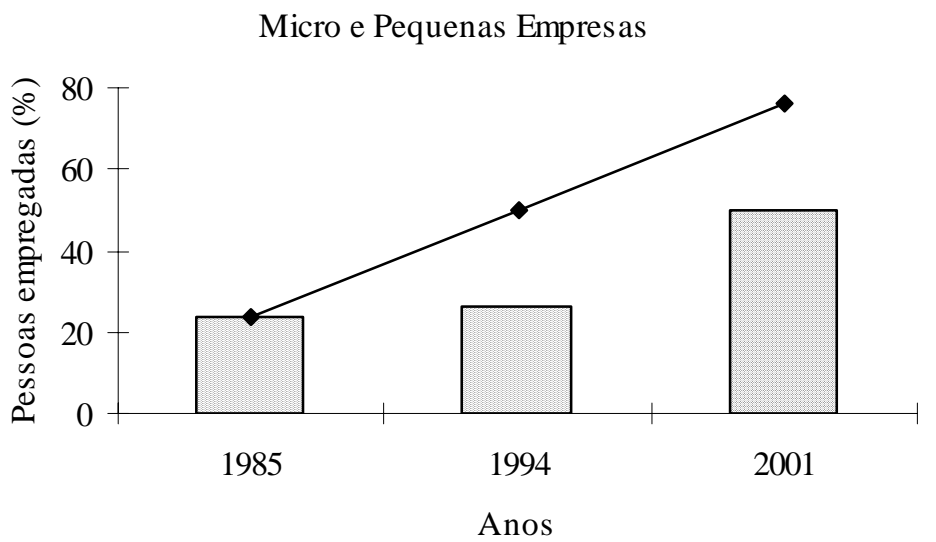

Figura 5 - Geração de postos de trabalho pelas micro e pequenas empresas nacionais no setor de comércio e de serviços em 1985, 1994 e 2001 (Instituto brasileiro de geografia e estatística, 2001) 


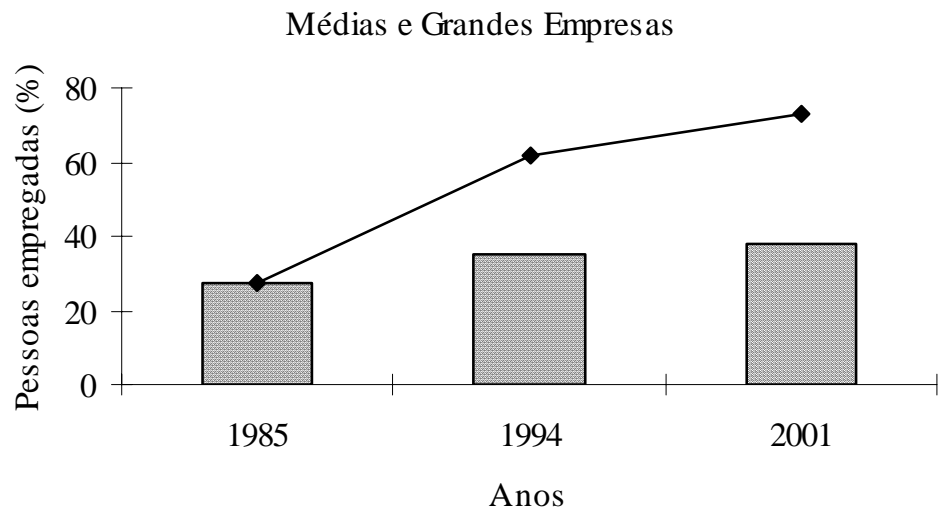

Figura 6 - Geração de postos de trabalho pelas médias e grandes empresas nacionais no setor de comércio e de serviços em 1985, 1994 e 2001 (Instituto brasileiro de geografia e estatística, 2001)

O Banco Nacional do Desenvolvimento Social (BNDES, 2003), durante o ano de 2003, efetuou cerca de 96.486 operações de análise e aprovação de crédito com pequenas e médias empresas, gerando um total de financiamento concedido de US\$ 29,56 bilhões, valor 20\% superior ao ano de 2002 (US\$ 24,58 bilhões).

As micro, pequenas e médias empresas tem significativa importância nas exportações do país, respondendo por cerca de 30,28\% dos recursos exportados em 2001 (BNDES, 2003). A Tabela 1, ilustra o valor exportado, segundo o tamanho das empresas. 
Tabela 1. Valor exportado (US\$ milhões) segundo tamanho das empresas brasileiras durante o período de 1999 a 2001

\begin{tabular}{ccccccc}
\hline \multirow{2}{*}{ Tamanho } & \multicolumn{7}{c}{ Valor exportado no ano (US\$ x 10 ${ }^{3}$ ) } \\
da firma & \multicolumn{2}{c}{1999} & \multicolumn{2}{c}{2000} & & \\
& US\$ & $\%$ & US\$ & $\%$ & US\$ & $\%$ \\
\hline Micro & $3.247,3$ & 6,8 & $3.131,8$ & 5,7 & $3.329,1$ & 5,8 \\
Pequena & $4.084,8$ & 8,5 & $4.272,8$ & 7,7 & $4.378,1$ & 7,6 \\
Média & $9.066,8$ & 18,9 & $9.451,9$ & 17,2 & $9.782,4$ & 16,9 \\
Grande & $31.540,9$ & 65,8 & $38.162,2$ & 69,4 & $40.262,8$ & 69,7 \\
Total & 47939,8 & 100 & 55018,7 & 100 & 57752,4 & 100 \\
\hline
\end{tabular}

Fonte: FUNCEX citado por BNDES (2003)

Em decorrência do favorecimento da economia mundial para exportações e conseqüente aumento da produtividade para suprir essa demanda, surge a necessidade do setor florestal se enquadrar rapidamente ao novo cenário de desenvolvimento e competitividade global que teve início na década de 90 e até hoje influi diretamente no gerenciamento de negócios voltados a suprir as necessidades dos clientes internos (mercado nacional) e externos (mercado global). O primeiro fator de mudança que atingiu não somente o setor florestal brasileiro, mas toda economia mundial foi a globalização que expandiu as preocupações com competição, monitoramento de mercado, qualidade do produto final e satisfação do cliente a níveis mundiais. O segundo 
fator de mudança é a transformação da economia industrial, que passa a ser fortemente influenciada por fatores como a liderança, produtividade (gerenciamento da produção), vida útil dos produtos, gerenciamento de resíduos e desenvolvimento de novos produtos e serviços. Estas novas preocupações passam a ser consideradas como fatores de grande competitividade e sucesso para as empresas (Laudon \& Laudon, 1994).

O setor florestal tem se inserido cada vez mais na globalização, o que tem gerado a necessidade de fortalecimento dos processos produtivos internos, visando o crescimento dinâmico e sustentado e impedindo a geração de desequilíbrios nas relações comerciais e financeiras tão frágeis nas empresas de pequeno e médio porte do setor (Associação brasileira da madeira processada mecanicamente, 2003).

Nesse ambiente competitivo torna-se indispensável a utilização de ferramentas de tomada de decisões gerenciais que auxiliem os administradores e acionistas a gerenciar a empresa de forma competitiva, dinâmica e flexível para se adaptar a novos mercados e clientes (Pongeluppe, 2002).

\subsection{Qualidade e suas dimensões}

A primeira preocupação com o termo qualidade é registrada nos séculos XVIII e XIX quando toda fabricação era feita por artesãos que trabalhavam sob a supervisão de mestres de ofício. A produção se caracterizava pela pequena quantidade, o ajuste era manual e a inspeção informal de produtos prontos surgiu como forma de assegurar a 
qualidade. A inspeção formal surge com a produção em massa e com a necessidade de produção de peças intercambiáveis, principalmente material bélico. Em 1922 surge oficialmente o controle de qualidade com a publicação de "The Control of Quality in Manufacturing” de autoria de Radford, G.S., em que a qualidade é vista pela primeira vez como responsabilidade gerencial distinta e independente. Em 1931 Shewart, W. A., criador dos gráficos de controle, uma das ferramentas mais poderosas do controle estatístico de processos, e do Ciclo PDCA (Plan Do Check Action) ferramenta fundamental para o gerenciamento da qualidade, publica "Economic Control of Quality of Manufactured Product” que trata cientificamente do controle de qualidade. Os conceitos de controle de qualidade utilizando fundamentação estatística são amplamente utilizados na década de 40 na inspeção de material bélico utilizado na Segunda Grande Guerra. Na década de 50, a qualidade deixa de ser baseada na produção e passa a considerar a quantificação de custos, zero defeito, controle total e engenharia da confiabilidade (Garwin, 1988).

Após o final da Segunda Guerra Mundial foram encaminhados especialistas para ajudar na reconstrução da indústria japonesa e assim, muitas técnicas que ajudaram os Estados Unidos da América a vencer o Japão em tempos de guerra, também seriam utilizadas para sua reconstrução (Sarriés, 1997). Até o final da Segunda Grande Guerra, o controle de qualidade não era uma prática incorporada pelas empresas japonesas, e seus produtos eram sinônimo de bens inferiores e de qualidade incerta. Com a adoção do TQM - “Total Quality Management” (gerenciamento pela qualidade total), o Japão reergueu sua economia e sua produção é caracterizada e reconhecida como excelência 
em qualidade (Shiba et al., 1993). Nos anos 70 e 80 os aspectos estratégicos da qualidade são reconhecidos e amplamente incorporados praticamente nas organizações do mundo inteiro (Garwin, 1988).

O termo qualidade, segundo a norma NBR ISO 9000, é o grau no qual um conjunto de características inerentes satisfazem uma necessidade ou expectativa, que geralmente é expressa de forma implícita ou explícita (ABNT, 2000). Cross \& Lynch (1990) definem qualidade a partir do ponto vista do cliente e afirmam que esta percepção é a grande responsável pela sucesso e diretrizes do negócio. A definição de qualidade pode ser representada como:

Satisfação do cliente $(\mathrm{SC})=$ Performance $(\mathrm{P})-$ Expectativas $(\mathrm{E})$.

A qualidade é positiva quando a performance excede as expectativas e conseqüentemente a insatisfação ocorre quando a performance é menor que as expectativas. Desta forma, não é a performance que precisa ser gerenciada, mas sim as expectativas que geralmente são criadas a partir de troca de experiências entre o cliente e suas experiências com o uso de produtos ou serviços da concorrência.

A qualidade total é definida por Campos (1992), como as dimensões que afetam a satisfação das necessidades, implícitas e explicitas, dos clientes internos ou externos e tem influência direta na sobrevivência de uma organização empresarial. O mesmo autor afirma que a qualidade está diretamente ligada à satisfação do cliente e é medida pelas 
características do produto ou serviço. Merli (1993) considera a satisfação do cliente como o fator fundamental de sucesso de um negócio e a interferência desse fator na organização ocorre a médio e longo prazo. Slack et al.(1999) e Kyan (2001) definem qualidade como "fazer certo”, ou seja, fornecer produtos ou serviços que realmente são o que devem ser, livres de qualquer tipo de problema. A qualidade total tem cinco dimensões também chamadas de componentes ou características da qualidade. Para que as necessidades do cliente possam ser atingidas e sua satisfação alcançada as cinco dimensões da qualidade total: qualidade intrínseca, custo, entrega, moral e segurança devem ser plenamente atendidas pelo produto oferecido para o cliente (Dellaretti Filho \& Drumond 1994; Campos, 1992). A Figura 7 ilustra o conceito de qualidade total e suas dimensões.

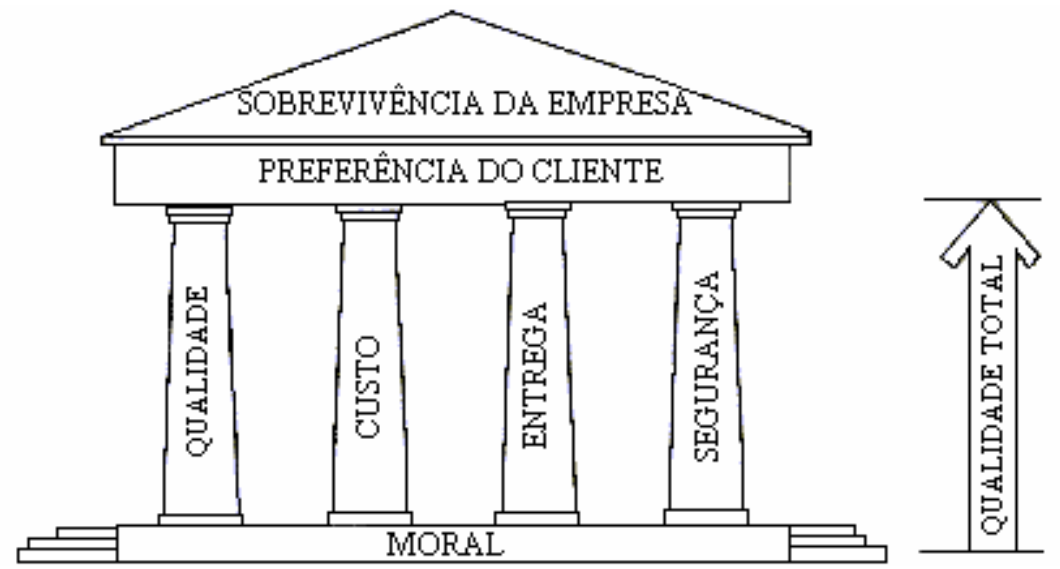

Figura 7 - Dimensões da qualidade total (Dellaretti Filho \& Drumond, 1994) 
A qualidade como dimensão é definida como um conjunto características específicas do produto que o tornam adequado às necessidades dos clientes (Dellaretti Filho \& Drumond, 1994). O custo está presente em todos os processos da empresa (Campos, 1992) e é a dimensão mais importante, sendo sua redução um dos principais objetivos da produção e é além disso um fator de vantagem competitiva (Slack et al. 1999; Dellaretti Filho \& Drumond, 1994; Campos, 1992). A entrega significa fornecer aos clientes o produto final no prazo e nas quantidades e especificações requeridas (Campos, 1992). A moral é um importante índice motivacional que mede o nível médio de satisfação dos funcionários (Campos, 1992) e possui forte influência na qualidade do produto (Dellaretti Filho \& Drumond, 1994). A quinta e última dimensão da qualidade é

a segurança que está relacionada tanto aos fatores envolvidos durante o processo produtivo quanto aos usuários finais do produto (Dellaretti Filho \& Drumond, 1994; Campos, 1992). Portanto, para atingir a qualidade total, estas dimensões devem ser consideradas e os resultados medidos em todos os processos para avaliar se o objetivo de atingir a qualidade total foi ou não atingido (Campos, 1992).

\subsection{Indicadores de Desempenho}

Com a aceleração do processo de desenvolvimento tecnológico e as crescentes mudanças de perfis de mercado, as organizações necessitam estar atentas a suprir todas as necessidades geradas por estas mudanças, como busca de novas soluções, conhecimento de posição no mercado e necessidade de clientes, análise de produto e 
busca por excelência. Para que as organizações possam acompanhar as tendências de mercado e desenvolver inovações para garantir competitividade e aprendizagem organizacional, a tomada de decisões dentro da organização deve ser baseada em informações confiáveis e objetivas, ou seja, utilizar a gestão por fatos e dados.

Macedo-Soares \& Ratton (1999), destacam que o objetivo da gestão por fatos e dados não é cobrir toda a extensão do conhecimento sobre um negócio e as contingências que o envolvem, mas possuir a informação que forneça dados para a tomada de decisões eficazes.

A informação é um produto de todas as atividades de rotina desenvolvidas dentro da organização e quando bem gerenciada é considerada um diferencial competitivo fundamental que garante agilidade no processo de tomada de decisões. As informações diferem conceitualmente de dados. Segundo Kaydos (1991), os dados são definidos como uma coleção de pontos e números enquanto que a informação é o resultado da conversão dos dados de forma que esses possam ser utilizados para tomada de decisão. Lebas (1995) complementa que os dados geralmente retratam o passado e somente se tornam informação quando são utilizados no processo de tomada de decisão ou quando são transformados em parâmetros para serem utilizados no processo.

A informação é fundamental no apoio às estratégias, processos de tomada de decisão, bem como no controle das operações empresariais e sua utilização representa uma intervenção no processo de gestão, podendo inclusive, provocar mudança 
organizacional, à medida que afeta os diversos elementos que compõem o sistema de gestão. O recurso da informação, quando devidamente estruturado, integra as funções das várias unidades da empresa, por meio dos diversos sistemas organizacionais (Beuren, 2000).

Andriani (2003) comenta que a informação permite o entendimento das tendências futuras para o negócio, estudos de cenários e utiliza o capital intelectual na organização visando a realização de inovações necessárias devendo estar fortemente fundamentada no “Core Bussiness” (fundamental para o negócio) para que haja foco de atuação e busca pela melhor resposta de transformação de entrada (“input”) em saída (“out put”).

Segundo ABNT - Associação Brasileira de Normas Técnicas (2000), medir é determinar o valor de uma grandeza. Kiyan (2001) afirma que o ato de medir engloba um conjunto de atividades, técnicas e de pressupostos que visam quantificar variáveis e atributos de interesse de qualquer item ou objeto a ser analisado.

Lebas (1995) salienta a importância do realização das medidas de desempenho e afirma que sem a medição não é possível o gerenciamento de uma organização. O mesmo autor define medição como sendo uma tarefa complexa de transformação da realidade em uma seqüência de símbolos comunicáveis e representativos que podem ser reproduzidos em circunstâncias similares. 
O sistema de medição é uma rede que permite monitorar todas as informações geradas em qualquer processo desenvolvido e fornece subsídios para análise do processo em relação a resultados e metas. Os indicadores são definidos como funções que permitem a obtenção de informações sobre medidas relacionadas a um produto, processo, sistema ou uma grandeza ao longo do tempo e quando esses indicadores são organizados em uma construção estruturada tem-se um sistema de medição (Macedo Soares \& Ratton 1999).

Neely (1988) destaca quatro dimensões que justificam a importância de realizar a medição de desempenho nas organizações: checar posição, comunicar posição, confirmar prioridades e alcançar o progresso. Checar a posição, é considerada uma regra essencial, pois saber onde se está e onde se quer chegar é crucial para a organização, não sendo possível gerenciar o que não se pode medir. Nesta etapa, devem ser enfocadas medidas que visem fornecer informações sobre a posição da organização, sua situação comparativa entre outras organizações (benchmarking) e medidas para monitorar o progresso. Comunicar a posição é fundamental tanto internamente, fornecendo "feedback" aos times de trabalho quanto a situação interna dos processos, e externamente quando a performance da organização é utilizada como marketing visando conquistar a fidelidade dos clientes. Confirmar prioridades enfatiza as medições que visam identificar quanto a organização está distante do alcance das metas. Para alcançar o progresso, realizar somente medição não é sinônimo de melhoria do desempenho devendo as medições serem utilizadas para comunicar prioridades e refletir motivação. 
Um sistema de medição de desempenho bem projetado e estruturado com objetivos definidos fornece uma base efetiva, desde que esse sistema seja utilizado como ferramenta de gestão (considerando a estrutura da organização, os processos, funções e seus relacionamentos) (Martins, 1999).

Segundo Bititci et al. (1997) o sistema de medição de desempenho é responsável por definir como a organização usa as informações geradas nos seus processos. O sistema de informação é considerado o “coração” do sistema de medição de desempenho tendo a função de fornecer “feedback” e promover o desenvolvimento de ações corretivas para as informações geradas. A Figura 8 ilustra a posição do sistema de informação e o processo de gestão de desempenho.

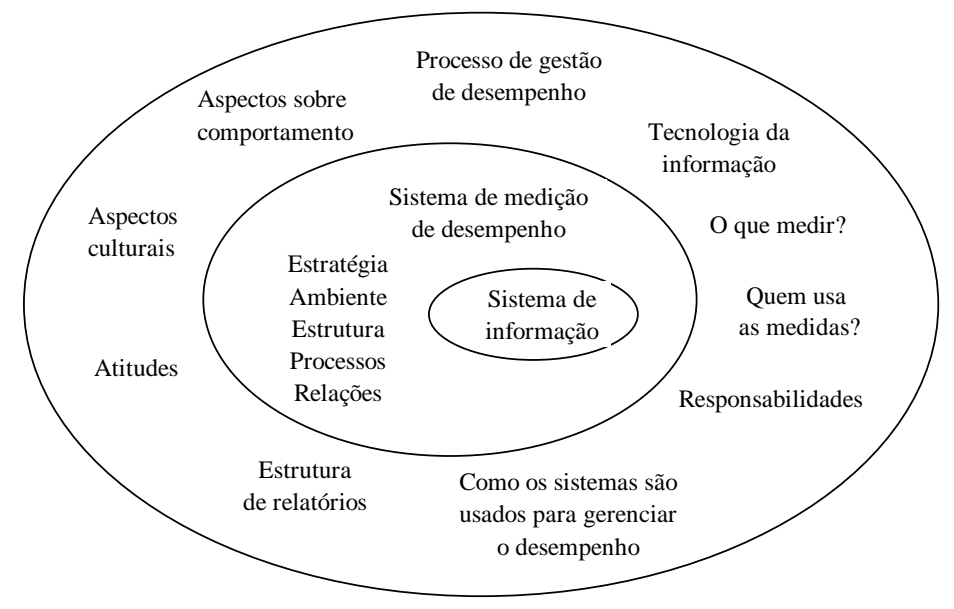

Figura 8 - Processo de gestão do desempenho e a posição do sistema de informação (Bittici et al., 1997) 
O processo de gestão de desempenho é utilizado pelas empresas como processo base para a tomada de decisões estratégicas, tanto corporativas como funcionais, focadas em seus objetivos. O sistema de medição de desempenho tem a função de integrar todas as informações relevantes para a organização (Martins, 1999).

O processo de gerenciamento dentro da organização é ilustrado na Figura 9 bem como o relacionamento existente entre a medição de desempenho e a gestão do desempenho sob a perspectiva da informação. Na Figura, o processo de gestão é dividido em quatro passos e tem início no processo produtivo com a criação de produtos e serviços. Essas atividades geram dados e o sistema de informação utiliza esses dados convertendo-os em informação útil passível de utilização. No processo de tomada de decisão se realiza uma análise da informação recebida e com base nessas toma-se decisões para alocar recursos e providenciar a tomada de ação, produzindo bens e serviços. O desempenho é resultado das decisões tomadas e desta forma a qualidade da decisão é limitada pela informação disponível em termos de quantidade e qualidade. O benefício mais importante de medição de desempenho adequada é o entendimento de como o sistema de produção funciona e quais são as forças que o influenciam identificando principalmente problemas e oportunidades de melhoria e desta forma o sistema de medição é constantemente enriquecido (Kaydos, 1991). 
Produtos/serviço

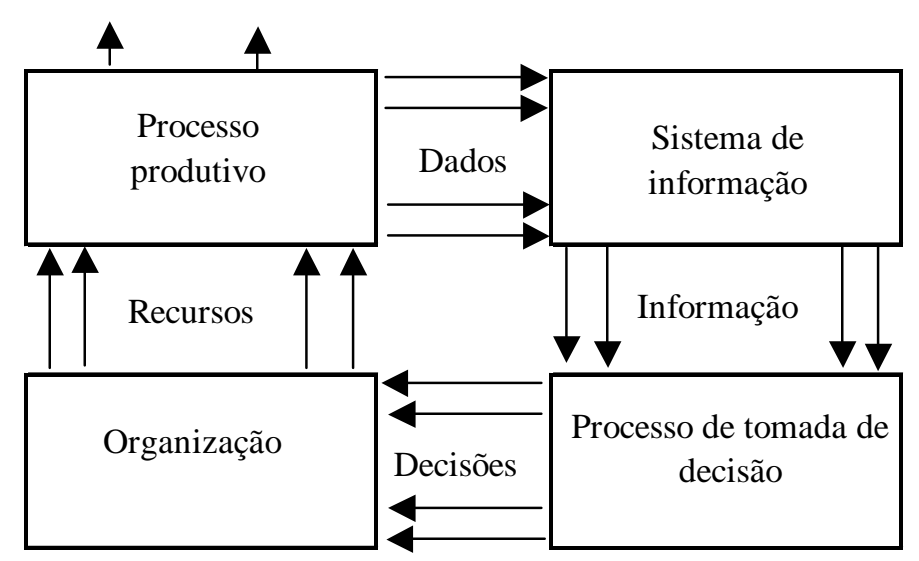

Figura 9 - Os quatro passos do processo de gestão (Kaydos, 1991)

\subsubsection{Evolução dos sistemas de medição}

Em 1920 Walter Shewart trabalhando na Bell Labs foi o primeiro pesquisador a utilizar o controle estatístico para monitorar e controlar processos. Durante a segunda Guerra Mundial o controle de qualidade tem importância fundamental para averiguar a qualidade e a confiabilidade dos materiais bélicos (Wang, 2004). Na década de 50 os sistemas de informação eram sistemas operacionais, nos quais a medição do desempenho era basicamente uma checagem realizada ao final de cada processo (Laudon \& Laudon, 1994). Já na década de 60 a medição de desempenho estava associada à estratégia “top down” (de cima para baixo), padronização e eficiência, resultados em conformidade com os planos, sem surpresas e constância nos planos (Ponpeluppe, 2002). 
Anteriormente à década de 80, os administradores não necessitavam saber como as informações eram coletadas, distribuídas em suas organizações, e a tecnologia envolvida era mínima. A informação em si, não era considerada importante, era simplesmente vista de forma limitada como o custo gerado ao longo do processo produtivo de um produto e suas implicações nos negócios da empresa (Laudon \& Laudon, 1994).

Martins (1999) apresenta um levantamento de trabalhos publicados sobre sistemas de medição de desempenho e constatou que ocorreu um considerável aumento a partir da década de 90, sendo que tal fato ocorreu após a publicação de artigos do Professor Robert S. Kaplan em 1983, 1984 ( publicações da Harvard Bussiness School) e 1991. Esses trabalhos alertam para a necessidade evidente de desenvolvimento de novas pesquisas nesta área. O crescente interesse no assunto é atribuído à inadequação do paradigma fordista/taylorista da produção em massa e seus instrumentos de gestão diante das mudanças do ambiente interno e externo ocorrido ao longo do período dos anos 80 até os anos 90 .

A década de 90 é marcada por fortes mudanças do cenário mundial no que diz respeito ao mundo dos negócios. O primeiro fator de mudança é a globalização que surge estendendo a competição a níveis mundiais, assim como o gerenciamento e monitoramento do mercado ("marketplace”), os grupos de trabalho e os sistemas de distribuição que também atingem repercussões mundiais. O segundo fator de mudança é 
a transformação da economia industrial, onde a liderança, produtividade, desenvolvimento de novos produtos e serviços, vida útil de produto e gestão do conhecimento passam a ser considerados fatores de grande competitividade e o sucesso das empresas depende de capacidade de gerenciar estes fatores de forma global (Laudon \& Laudon, 1994).

Os anos 90 destacam-se por ser um período de transição entre a predominância das medidas de desempenho tradicionalmente financeiras e o surgimento de novas técnicas como o "Balance scorecard" e do "Modelo de excelência de negócios" desenvolvido pela Fundação Européia para o Gerenciamento da Qualidade (Holloway, 2001).

Os sistemas de informação na década de 90 estão direcionados em como tomar decisões e planejar para o desenvolvimento e produção de bens e/ou serviços. Atualmente, estes sistemas são estratégicos na rotina das empresas, sempre visando o controle e comparação de resultados como auxiliar no processo de tomada de decisão. Desse modo, são parte integrante do processo de administração estratégica e este conceito de administração envolve o planejamento e a estruturação organizacional para suportar a estratégia determinada, o processo diretivo, o sistema de avaliação, acompanhamento e a efetivação das mudanças (Pongeluppe, 2002). 


\subsubsection{Desenvolvimento de indicadores de desempenho}

Kiyan (2001) realizou um trabalho com o objetivo de desenvolver uma sistemática para criar indicadores de desempenho que viabilizassem a operacionalização da estratégia empresarial, ficando o relacionamento entre os indicadores e a promoção de melhorias em processos considerados críticos. A metodologia adotada é composta de três etapas: a primeira é a análise ambiental que consiste em definir qual a contribuição dos indicadores de desempenho para atingir objetivos estratégicos; a segunda é a definição do conjunto de indicadores; e a terceira detalha cada indicador. O autor concluiu que para o desenvolvimento dos indicadores é importante utilizar como critério as dimensões da qualidade com enfoque na redução de custos. Esse enfoque é tão importante para a empresa quanto o desenvolvimento de indicadores que possibilitem o conhecimento do processo produtivo. Aliando esses dois enfoques, é possível obter uma análise mais profunda da organização e do ambiente externo.

Os benefícios da medição de desempenho podem surgir antes que os indicadores gerem as primeiras informações, pois o processo de desenvolvimento promove uma ampla visão da empresa e do seu ambiente, que resulta em um importante passo para a melhoria do desempenho global do negócio. O ato de medir o desempenho é um processo de negociação de interesses entre os "Stakeholders" (acionistas, empregados, sociedade e clientes) da organização. A análise dos indicadores é um importante exercício para identificação de problemas na empresa (Kyan, 2001). 
Neely et al. (2000) descrevem uma proposta metodológica composta por doze fases para o desenvolvimento de um sistema de medição de desempenho: Fase 1 Identificação das áreas passíveis de monitoramento; Fase 2 - Análise do custo-benefício de cada medida de desempenho; Fase 3 - Definição do propósito da medição de desempenho; Fase 4 - Checagem das medidas; Fase 5 - Determinação da estrutura das medidas de desempenho; Fase 6 - Integração das medidas de desempenho; Fase 7 Considerações ambientais; Fase 8 - Teste interfuncional; Fase 9 - Considerações ambientais interfuncionais; Fase 10 - Teste destrutivo interfuncional; Fase 11 Institucionalização das medidas de desempenho; Fase 12 - Manutenção do sistema.

Os autores aplicaram este método em três diferentes ramos de negócio e os resultados comprovaram que a metodologia proposta é capaz de desenvolver um sistema de informações robusto e confiável.

\subsection{Uso de ferramentas gerenciais}

O sucesso na utilização das ferramentas gerenciais está diretamente ligado à disponibilidade, acesso, registro, qualidade da informação e envolvimento de todos na organização. O uso da informação para controle e avaliação dos resultados ao final de cada processo, associado à autonomia dada aos funcionários para a tomada de decisão com base no uso de ferramentas gerenciais gera agilidade no processo produtivo através da solução rápida de problemas e comparação de resultados, podendo modificar ou confirmar os objetivos e os recursos empregados ao longo do processo. Desse modo, as 
ferramentas gerenciais aliadas à informação passam a ser parte integrante do processo de administração estratégica (Pongeluppe, 2002).

A tarefa de controle e avaliação de resultados não deve ser realizada como uma avaliação estática, afinal é um processo que deve ser executado de forma contínua, durante cada tarefa, utilizando as modernas técnicas de gestão, como por exemplo, o TQC - Total Quality Control - controle de qualidade total, essa avaliação e controle deve ser de responsabilidade de cada executor. O ser humano é que gera qualidade, no ato da realização das suas ações e não mais, como era no conceito antigo, deixar a cargo de uma área de "controle” e verificar a qualidade dos serviços/produtos decorrentes de cada tarefa (Cassarro, 1999).

A preocupação com a garantia de fornecer produtos de qualidade e sem defeitos é constante para todos os fornecedores de produtos e serviços e cada vez mais o cliente espera um produto confiável, que apresente um nível de desempenho especificado com alta durabilidade e baixo índice de falhas. Visando garantir o aumento da confiabilidade e prevenir problemas, surge um novo enfoque de qualidade voltado à conformidade e que tem como objetivo a solução de problemas encontrados ao longo do processo produtivo. Para isso, os métodos FMEA (Failure Mode and Effect Analysis) e Diagrama de Ishikawa são utilizados para buscar as causas fundamentais desses problemas (Helman, 1995; Stamatis, 1995). 


\subsubsection{FMEA - Failure Mode and Effect Analysis}

O FMEA foi desenvolvido em 1949 por militares americanos, com objetivo de determinar o efeito da ocorrência de falha em sistemas e em equipamentos. A partir de 1988 começou a ser utilizado em empresas como a Chrysler, Ford e General Motors como parte dos chamados programas avançados de planejamento da qualidade em projetos e processos (Fmeca.com, 2003). Segundo Teng \& Ho (1996) essa técnica é utilizada na engenharia com a finalidade de encontrar falhas potenciais durante a etapa de projeto reduzindo assim, os custos de correções futuras.

O FMEA (análise de modo de falhas e seus efeitos) é uma ferramenta freqüentemente utilizada para avaliar o potencial e conseqüência das falhas dos componentes e sistemas (hardwares) utilizados nos projetos desenvolvidos pela National Aeronautics and Space Administration (NASA) (Ruttledge, 2004).

Todo processo dentro de uma organização é formado por um conjunto de causas que provocam um ou mais efeitos (Campos, 1992). Segundo Helman (1995) o FMEA é um método analítico padronizado utilizado para detectar e eliminar problemas potenciais de forma sistemática e completa. Consiste na identificação de todos os possíveis modos potenciais de falha e determina o efeito de cada uma sobre o desempenho do sistema

(produto ou processo). É um método de estudo das causas fundamentais dos problemas de produtos e/ou processos e tem como principal objetivo, identificar e hierarquizar as 
falhas críticas, apontando o potencial de risco de cada uma e auxiliando na elaboração de um plano de ação para o bloqueio das falhas detectadas.

Stamatis (1995) define FMEA, como sendo uma técnica sistemática que utiliza os conceitos de engenharia e de desenvolvimento de técnicas organizacionais para otimizar o sistema, produto, processo e/ou serviço e tem como principal objetivo enfatizar a minimização da probabilidade de ocorrência da falha e de seu efeito. Como benefícios de sua utilização destacam-se: melhoria da qualidade; segurança dos produtos e serviços; melhoria da imagem da empresa e sua competitividade; ajuda a aumentar a satisfação do cliente; reduz custo e tempo de desenvolvimento de produto; auxilia no diagnóstico de processos; estabelece prioridades para implantação de ações corretivas.

A técnica FMEA, segundo Teng \& Ho (1996), pode ser resumida em três passos: o primeiro identifica o potencial do modo de falha (que são os eventos que podem causar perda de desempenho) durante o ciclo de vida de um produto. O segundo passo é o efeito que essa falha pode causar e o terceiro identifica o quanto a falha pode afetar o funcionamento do produto.

Para cada falha identificada ao longo do processo são atribuídos índices de ocorrência, severidade e detecção. Esses índices podem variar de 1 a 5 (escala de Likert) que fornece uma interpretação mais fácil de ser feita, ou de 1 a 10 . Através da multiplicação dos três índices obtém-se o índice de risco e consequentemente a falha que tem prioridade para ser trabalhada (Stamatis, 1995). 
O índice de ocorrência é uma estimativa das probabilidades combinadas de ocorrência de uma causa de falha e dela resultar o tipo de falha no produto/processo (Helman, 1995). Stamatis (1995) define ocorrência como sendo a freqüência da falha. O índice de severidade reflete a gravidade do efeito da falha sobre o cliente (interno ou externo) assumindo que o tipo de falha ocorra. E o índice de detecção avalia a probabilidade da falha ser detectada antes que o produto chegue ao cliente (Helman, 1995; Stamatis, 1995).

\subsubsection{Diagrama de Ishikawa}

O Diagrama de Ishikawa também conhecido como diagrama de espinha de peixe ou diagrama de causa e efeito, é utilizado para buscar a origem das não conformidades e suas inter-relações em um processo (Montgomery, 1985). Ele permite estruturar hierarquicamente as causas de um determinado problema ou oportunidade de melhoria, podendo ser utilizado para estruturar qualquer sistema que resulte em uma resposta (uni ou multivariada) de forma gráfica e sintética (Figura 10). As causas que geram um efeito são agrupadas utilizando 6M: máquina, método, meio ambiente, material, medidas e mão de obra, para identificar as causas de um efeito ou problema (Sarriés et al., 2004). Vieira (1999) afirma que os 6M são as causas primárias dos problemas que mais ocorrem nas indústrias; na área de serviços os 6M podem ser substituídos por equipamentos, políticas, procedimento e pessoal. 


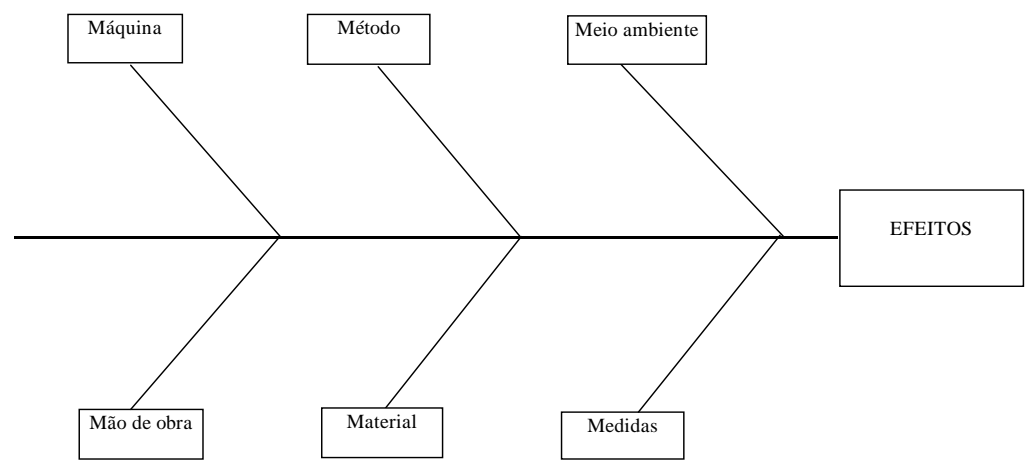

Figura 10 - Diagrama de Ishikawa (Vieira, 1999)

O desenvolvimento de um bom diagrama de causa e efeito depende do nível de conhecimento sobre o tema que está sendo desenvolvido (Montgomery, 1985). Dentro das fases do PDCA seu uso é indicado nas etapas de observação, identificação e análise de problemas (Dellaretti Filho, 1996). A fase P do ciclo PDCA é o planejamento e é composto por objetivo, meta e método; a fase D de desenvolvimento inclui treinamento a equipe e execução do método proposto; a fase C é a checagem cujo objetivo principal é verificar se a meta e o objetivos propostos foram ou não atingidos. Se os objetivos propostos não são atingidos utiliza-se a fase A ação corretiva do ciclo PDCA, assim o ciclo se reinicia até que o objetivo e a meta propostos sejam atingidos.

A Figura 11 ilustra o ciclo PDCA e relaciona as atividades desenvolvidas em cada fase do ciclo. 


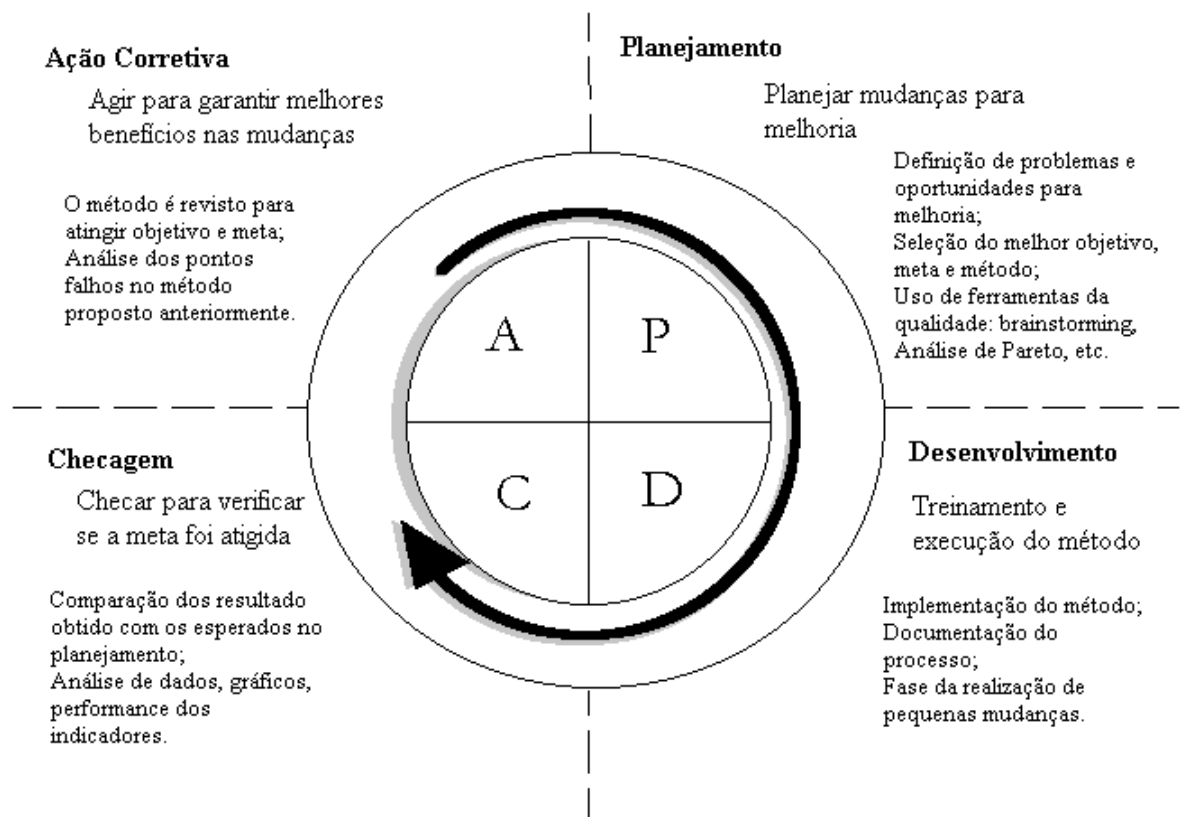

Figura 11 - Ciclo PDCA e seu desenvolvimento contínuo visando atingir a meta proposta (HCI Consulting, 2004) 


\section{MATERIAL E MÉTODOS}

\subsection{Caracterização da empresa do estudo de caso}

Este trabalho foi desenvolvido em uma empresa familiar de pequeno porte (27 funcionários), atuante no setor de beneficiamento de madeira serrada, localizada na cidade de Tietê, estado de São Paulo.

A empresa atua no mercado há vinte anos, fabricando guarnições, forros, rodapés, batentes, portas e esquadrias utilizando-se de madeira de várias espécies dentre elas: cedro (Cedrella spp.), freijó (Cordia goeldiana Huber.) e tamarindo (Tamarindus indica) para a fabricação de guarnições, caixilhos, janelas, cordões, molduras, vitrôs e portas.

O sistema produtivo é do tipo sob encomenda, não existindo uma padronização entre os produtos e nem quanto a modelos e dimensões. Os indicadores foram desenvolvidos para o processo produtivo da empresa e o desenvolvimento do método para elaborar os sistema de desempenho utilizou como base os trabalhos desenvolvidos por Kiyan (2001) e Neely et al. (2000). Essa metodologia foi aplicada somente às 
Unidades Gerenciais Básicas (UGB’s) que possuem relação direta com o processo produtivo.

\subsection{Desenvolvimento dos indicadores referentes ao processo de produção}

Os indicadores da produção foram desenvolvidos em uma seqüência, caracterizada por etapas, compreendendo: elaboração de fluxogramas de produção, identificação e caracterização do potencial de falha dos pontos críticos e suas causas e estabelecimento dos indicadores de desempenho.

\subsubsection{Fluxograma da empresa e do processo produtivo}

O desenvolvimento dos fluxogramas teve como base uma divisão já existente das etapas dos processos em Unidades Gerenciais Básicas, UGB’s, que são definidas como as menores células auto-gerenciadas da empresa, que se caracterizam por conhecerem as necessidades de seus clientes e as características de seus produtos. O principal critério utilizado para esta divisão é a definição dos processos dentro das UGBs (Andriani, 2002). Como o objetivo do desenvolvimento dos fluxogramas, consiste em definir os processos e as atividades a eles relacionados, a divisão em UGB's, pré existente, foi considerada adequada para ser utilizada na elaboração de dois fluxogramas: um contendo os principais processos da empresa e outro que detalha as etapas do processo produtivo. 
Os processos principais são aqueles diretamente envolvidos na fabricação do produto e comprometidos com a satisfação do cliente, foram definidos como: vendas, planejamento e controle da produção (PCP), produção, expedição, projeto e inovação, financeiro, compras, controle de qualidade e assistência técnica. Os processos denominados como apoio atuam como suporte para o desenvolvimento das atividades dos processos principais: recursos humanos, manutenção, informática, gestão pela qualidade, entrega e diretoria.

Os fluxogramas foram elaborados com as pessoas diretamente ligadas às atividades desenvolvidas em cada processo identificando as atividades de início (entrada) e fim (saída para a próxima etapa).

\subsubsection{Pontos críticos do processo}

Com a elaboração dos fluxogramas dos processos a próxima etapa foi a identificação dos pontos críticos, definidos como aqueles que possam vir a causar danos ao processo produtivo. Para identificação desses pontos críticos, realizaram-se reuniões com os funcionários ligados a cada um dos processos avaliados, utilizando-se a técnica “Brainstorming, não estruturado” em que todos os participantes podem contribuir com suas idéias livremente. Sarriés (2004) em comunicação pessoal, destaca que no uso do “Brainstorming estruturado” as opiniões são dadas em seqüência determinada, e no “não estruturado” os participantes podem contribuir com suas idéias livremente. 


\subsubsection{Definição dos potenciais críticos de falha}

Após identificação dos pontos críticos dos processo, esses foram submetidos a uma avaliação utilizando-se o FMEA - Failure Mode and Effect Analysis - com o objetivo de avaliar o potencial de falha existente para cada ponto crítico identificado no processo produtivo. Após cada falha ter sido identificada realizou-se uma estimativa de ocorrência, severidade e detecção, com base na escala de1 a 5. A estimativa da ocorrência, severidade e detecção foram obtidas através de índices com critérios para classificação esses são descritos nas Tabelas 2, 3 e 4.

Tabela 2. Índices e critérios de avaliação para o índice de ocorrência

\begin{tabular}{cl}
\hline Índice & Critérios para estimativas do índice de ocorrência \\
\hline 1 & Probabilidade muito remota de acontecer \\
2 & Número de ocorrências baixo \\
3 & Número de ocorrências moderado \\
4 & Número de ocorrências alto \\
5 & Falhas em proporções alarmantes \\
\hline
\end{tabular}


Tabela 3. Índices e critérios de avaliação para o índice de severidade

Índice Critérios para estimativas do índice de severidade

1 É razoável esperar que o cliente não perceba a falha

2 O cliente perceberá a falha mas não ficará insatisfeito por causa dela

3 O cliente perceberá a falha e ficará insatisfeito

$4 \quad$ O cliente ficará insatisfeito mas não tem sua segurança afetada

5 O cliente ficará muito insatisfeito e afeta a sua segurança

Tabela 4. Índices e critérios de avaliação para o índice de não detecção

Índice Critérios para estimativas do índice de não detecção

$1 \quad$ Probabilidade muito alta que a falha seja detectada

2 Probabilidade alta de que a falha seja detectada

3 Probabilidade média de que a falha seja detectada

$4 \quad$ Probabilidade baixa de que a falha seja detectada

5 Probabilidade muito baixa de que a falha seja detectada

O próximo passo após a avaliação das estimativas é o cálculo do índice de risco, obtido pela multiplicação dos três índices:

Índice de Risco (IR) = Ocorrência (O) x Severidade (S) x Detecção (D) 
De acordo com Sarriés ${ }^{1}$ a inclusão do fator custo com peso dois (x 2) na fórmula para cálculo do índice de risco. O índice de risco, para este trabalho, teve como objetivo priorizar as ações corretivas e indicar os pontos críticos para estudo da causa.

\subsubsection{Estudo das causas dos pontos críticos}

Após a aplicação do FMEA (modo de análise de falha e seus efeitos), uma reunião foi realizada com os funcionários envolvidos em cada processo analisado sendo as falhas comuns agrupadas. Um estudo da causa foi realizado utilizando o diagrama de Ishikawa para analisar as relações de causa e efeito e identificar as causas de cada falha para estudá-la de forma hierárquica, utilizando critérios de prioridade do índice de risco fornecido pelo FMEA.

Durante o preenchimento do Diagrama de Ishikawa as prováveis causas foram classificadas em material, método, mão de obra, máquina, meio ambiente e medidas (6 M’s). Em seguida as causas mais prováveis foram apontadas como “causas raízes” ou principais, responsáveis por provocar a falha.

\footnotetext{
${ }^{1}$ SARRIÉS, G.A. Comunicação pessoal, 2004.
} 


\subsubsection{Medidas de desempenho}

A partir da identificação das causas responsáveis por gerar as falhas, essas foram monitoradas utilizando os indicadores de desempenho. O desenvolvimento dos indicadores foi contínuo e os resultados obtidos foram analisados em reuniões periódicas de análise crítica. As reuniões tiveram como objetivo verificar se as medidas de desempenho satisfazem às necessidades internas da organização e para assegurar que medidas de desempenho redundantes, obsoletas e sem aproveitamento do sistema sejam identificadas, revisadas e/ou descartadas. 


\section{RESULTADOS E DISCUSSÃO}

\subsection{Fluxograma da empresa}

A Figura 12 ilustra a interação entre os processos principais e os de apoio. Os primeiros são conectados por setas e as atividades desenvolvidas por eles são ligadas diretamente ao processo de fabricação do produto. Os segundos fornecem suporte para as atividades desenvolvidas nos processos principais.

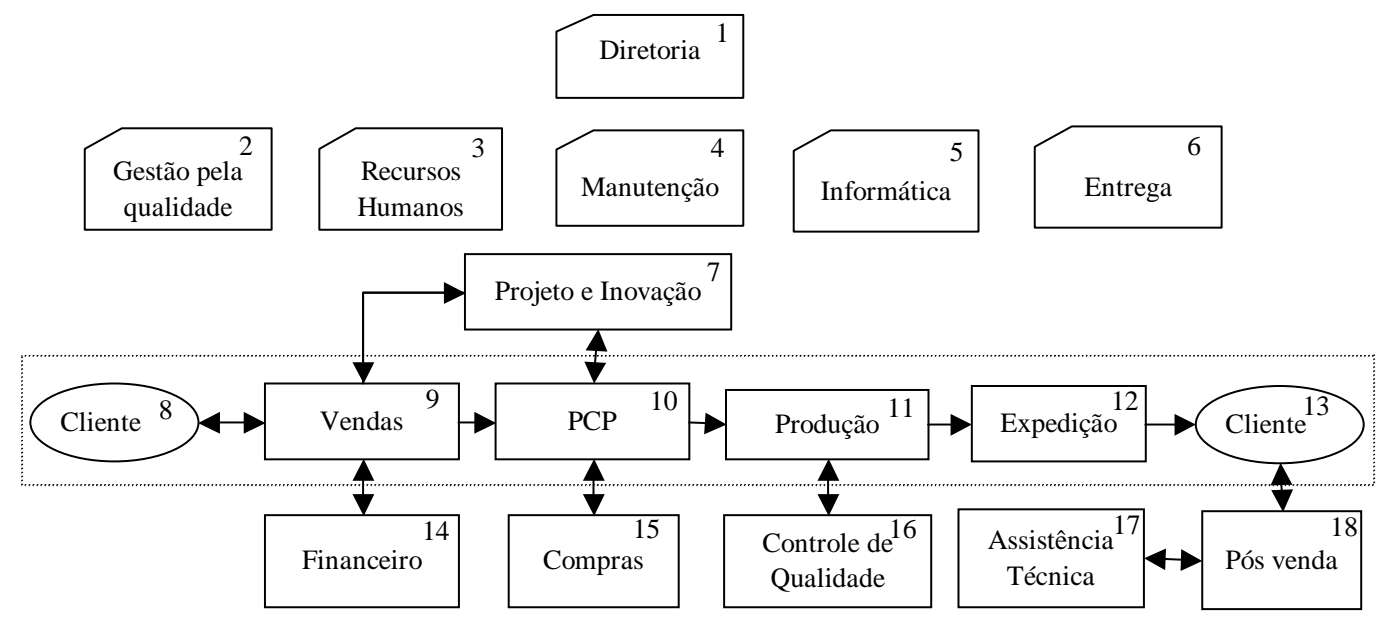

Figura 12 - Interação entre os processos da empresa 
Na Figura 12, os números de 1 a 6 representam os processos de apoio que funcionam como suporte ao desenvolvimento das atividades aos principais representados pelos números de 7 a 17.

O contato com o cliente (8) e todas as atividades que envolvem o fechamento do pedido (prazo de entrega, orçamentos e definições do pedido) são feitas pela equipe de vendas (9).

O desenvolvimento de cada pedido segue os requisitos fornecidos pelo cliente durante a negociação com a equipe de vendas. A venda (9) é o primeiro processo da empresa e é responsável por manter um interação entre o projeto (7), financeiro (14) e o planejamento e controle da produção - PCP (10), visando sempre a garantia da satisfação do cliente. Entre a venda (9) e o projeto (7) existe uma relação de troca de informações quanto aos requisitos necessários para elaboração do pedido e possíveis alterações propostas pela equipe de projetos ou cliente. Entre a venda (9) e o financeiro (14) há troca de informações sobre formas de pagamento, parcelamentos e aprovação do crédito. Entre a venda (9) e PCP (10) existe uma relação de negociação quanto aos prazos de entrega.

O PCP também troca de informações com a atividade de projetos e inovação (7), compras (15) e produção (11). Entre o PCP (10) e o projeto e inovação (7) há troca de informações sobre quantidade de matéria - prima necessária para fabricação do produto. 
A informação recebida é passada para compras (15) que verifica o estoque e avalia a necessidade de aquisição de matéria - prima. A produção (11) recebe do PCP (12) a planilha de produção contendo os pedidos e as metas de produção.

A produção (11) está diretamente relacionada com o controle de qualidade (16) e a expedição (12). O controle de qualidade (16) verifica a qualidade do produto final e fornece um “feedback” à produção, apontando necessidades de melhoria. A expedição (12) providencia a retirada do produto acabado da produção (11), encaminha as peças para carregamento, confere o carregamento e libera o caminhão.

Após a entrega da mercadoria, o pós venda (17) entra em contato com o cliente e realiza uma pesquisa de satisfação e em caso de alguma não conformidade ou reclamação, a assistência técnica (18) é contactada e efetua as providências necessárias para solução dos problemas.

\subsection{Fluxogramas do processo produtivo}

Os processos traduzidos no formato de fluxogramas foram: a secagem e armazenagem de madeira (depósito), pré corte de batente e caixilho, beneficiamento e montagem. O fluxograma do processo produtivo é apresentado na Figura 13. 


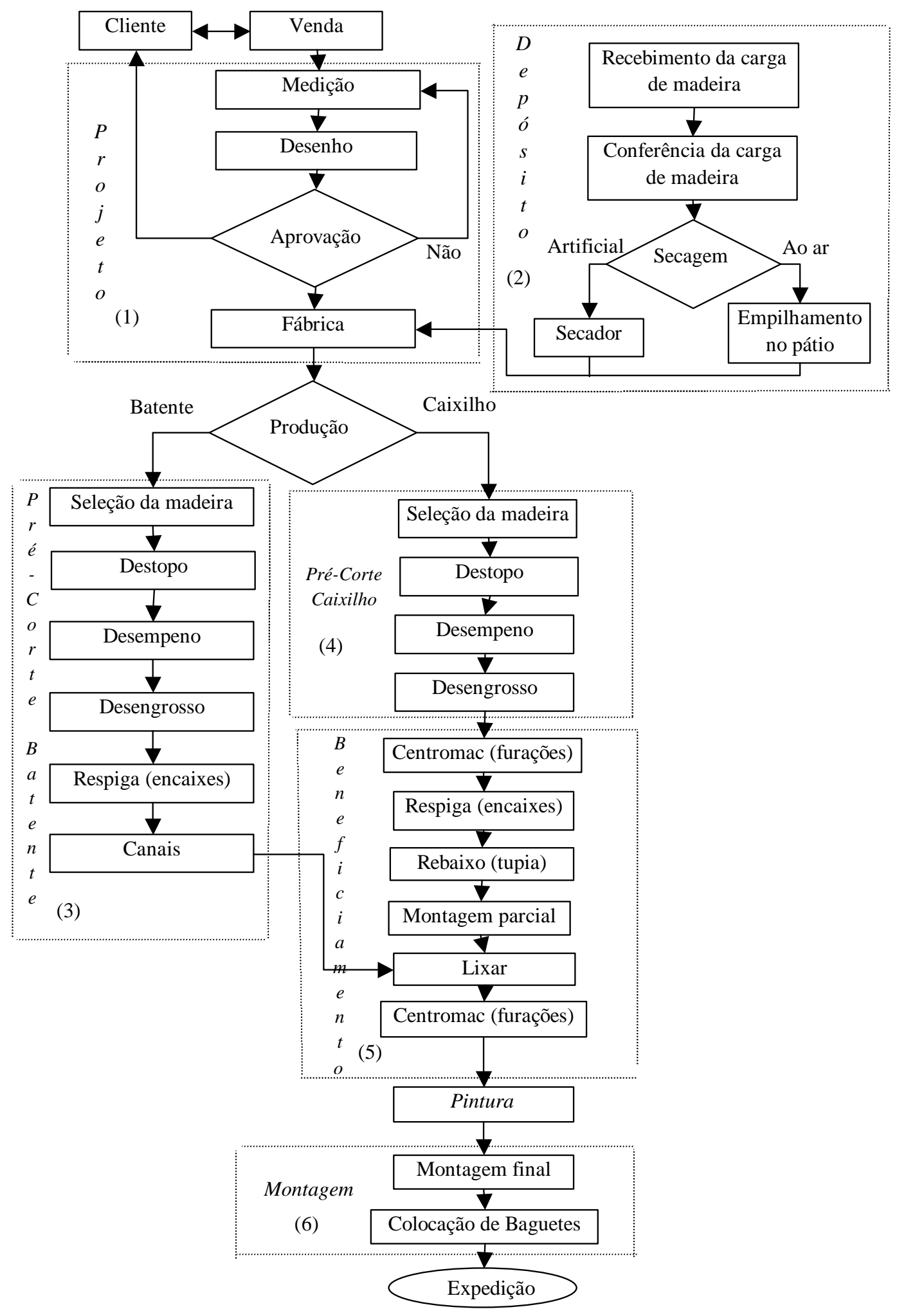

Figura 13 - Fluxograma do processo produtivo 
As atividades desenvolvidas por projetos (1), envolvem o contato direto entre a equipe de vendas e o cliente. O projeto tem início com o recebimento das plantas das obras contendo as dimensões dos vãos e preferências (modelo, matéria-prima) fornecidas pelo cliente. A partir desse ponto estabelece-se uma relação de troca de informações entre o cliente e a empresa para agendar a conferência de medidas e definição de pequenas pendências. Após a conferência das medidas os desenhos são elaborados e encaminhados ao cliente. Quando aprovados a planilha de produção é feita e encaminhada à produção.

As atividades desenvolvidas no depósito (2) tem início com o recebimento da carga de madeira e sua conferência. Nesse momento analisa-se a relação estabelecida com o fornecedor, verificando se os requisitos combinados no ato da compra foram ou não consolidados. Com base no controle de estoque e na demanda de matéria-prima pela fábrica, a madeira pode ser encaminhada para a secagem ao ar com empilhamento no pátio ou para secagem artificial com empilhamento dentro do secador. O empilhamento é um processo fundamental para garantir a qualidade da matéria-prima e a redução de perdas.

Saindo do depósito, a madeira é encaminhada para a fábrica e a primeira etapa do processo produtivo é a atividade de pré corte para fabricação de batentes (3) e caixilhos (4). Nessas etapas do processo, a madeira bruta cortada em pranchas é selecionada de acordo com os requisitos do projeto e potencial de aproveitamento de cada prancha; esse 
processo é composto por uma seqüência de atividades: destopo, desengrosso, desempeno, respiga e confecção de canais.

A atividade destopo é feita com a utilização da serra circular e consiste na eliminação de rachaduras das extremidades da prancha com defeitos, originando peças com faces planas. Durante essa atividade é realizado o primeiro corte com medidas aproximadas às especificadas no pedido. A próxima atividade é o desempeno que visa retirar pequenos defeitos e tortuosidades leves da prancha. A última atividade é o desengrosso e consiste na redução da espessura da prancha. Com estas três atividades seqüenciais a prancha é colocada nas dimensões certas para dar forma ao produto. A próxima fase é a realização dos encaixes, denominada respiga e a última etapa é a realização de canais para colocação de trilhos. Em seguida o batente é encaminhado para ser lixado e montado.

O beneficiamento (5) recebe as peças semi-prontas, do pré-corte de batente (3) e caixilho (4), para dar início ao acabamento das peças. As peças semi-prontas do précorte de caixilho (4) são parcialmente montadas, lixadas e furadas para colocação de ferragens. As peças recebidas do pré-corte de batente (3) chegam prontas e são apenas lixadas e em seguida encaminhadas para a montagem (6).

A pintura recebe todas as peças que passaram pelo beneficiamento e realiza o acabamento final composto pelo lixamento manual e a pintura das peças. A próxima etapa do processo é a montagem (6) que efetua a montagem final de todas as esquadrias, 
portas, faz a colocação de ferragens (fechaduras, maçanetas) e acessórios (trilhos, telas) e os encaminha para a expedição.

\subsection{Pontos críticos dos processos}

A identificação dos pontos críticos (potenciais de melhoria) foi realizada através de reunião, gerenciada pela técnica "Brainstorming não estruturado”, com a participação de pessoas diretamente envolvidas nas atividades de rotina. Os pontos críticos identificados a partir dos fluxogramas e das reuniões são relacionados na Tabela 5.

Tabela 5. Pontos críticos levantados no processo produtivo de esquadrias

\begin{tabular}{ll}
\hline Processos & Pontos críticos \\
\hline Secagem e armazenagem da madeira & (A) Grande quantidade de madeira descartada \\
(B) Madeira exposta a tempo sem empilhar & (C) Perda de madeira \\
Pré - corte & (D) Presença de defeitos na madeira \\
(E) Retorno de peças & (F) Grande quantidade de sobras (madeira de \\
pequenas dimensões com baixo potencial de uso) & (G) Estoque insuficiente na fábrica \\
Beneficiamento & (H) Erros de dimensões \\
(I) Montantes fora de esquadro e rachados \\
(J) Erros na seleção da madeira e atraso de pedidos \\
(L) Pouco espaço para manuseio de peças \\
(M) Falta de agilidade no processo \\
(N) Alto consumo de tinta \\
(O) Peças fora de esquadro \\
(P) Ferragens colocadas em posição errada \\
(Q) Rachadura em batentes \\
(R) Lixamento pouco preciso \\
(S) Peças sem encaixe preciso
\end{tabular}


Tabela 5. Pontos críticos levantados no processo produtivo de esquadrias

\begin{tabular}{ll}
\hline Processos & Pontos críticos \\
\hline \multirow{3}{*}{ Projeto } & (T) Erros de medidas colhidas na obra \\
& (U) Erros de desenhos \\
& (V)Erros em textos de projetos \\
& (X) Erros em dimensionamento de peças \\
& (Z) Erros em cálculo de furos em peças de granito \\
\hline
\end{tabular}

\subsection{Definição dos potenciais críticos de falha}

O potenciais críticos de falhas resultam da aplicação do FMEA para cada ponto com potencial para melhoria. A Tabela 6 contém o resultado do FMEA e pontos críticos definidos para cada processo.

Tabela 6. Pontos críticos dos processos identificados pela aplicação do FMEA

\begin{tabular}{|c|c|c|c|c|c|}
\hline \multirow[b]{2}{*}{ Processos } & \multirow[b]{2}{*}{ Pontos críticos } & \multicolumn{4}{|c|}{ Índices } \\
\hline & & & 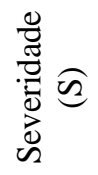 & 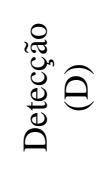 & 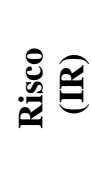 \\
\hline \multirow{3}{*}{$\begin{array}{c}\text { Secagem e } \\
\text { armazenagem } \\
\text { da madeira }\end{array}$} & (A) Grande quantidade de madeira descartada & 4 & 3 & 3 & 36 \\
\hline & (B) Madeira exposta ao tempo sem empilhar & 4 & 3 & 3 & 36 \\
\hline & (C) Perda de madeira & 4 & 3 & 4 & 48 \\
\hline \multirow{4}{*}{$\begin{array}{l}\text { Pré corte de } \\
\text { batente e } \\
\text { caixilho }\end{array}$} & (D) Presença de defeitos na madeira & 4 & 3 & 3 & 36 \\
\hline & (E) Retorno de peças com defeitos & 3 & 2 & 4 & 24 \\
\hline & (F) Grande quantidade de sobras & 4 & 4 & 4 & 64 \\
\hline & (G) Estoque de madeira insuficiente na fábrica & 2 & 3 & 3 & 18 \\
\hline \multirow{4}{*}{ Beneficiamento } & (H) Erros de medida & 3 & 3 & 1 & 9 \\
\hline & (I) Montante fora de esquadro e rachados & 4 & 3 & 3 & 36 \\
\hline & (J) Erros na seleção da madeira & 4 & 3 & 3 & 36 \\
\hline & (L) Atraso de pedidos & 4 & 3 & 1 & 12 \\
\hline \multirow{3}{*}{ Pintura } & (M) Pouco espaço para manuseio de peças & 4 & 3 & 2 & 24 \\
\hline & (N) Falta de agilidade no processo de pintura & 3 & 4 & 2 & 24 \\
\hline & (O) Alto consumo de tinta & 4 & 1 & 3 & 12 \\
\hline
\end{tabular}


Tabela 6. Pontos críticos dos processos identificados pela aplicação do FMEA

\begin{tabular}{|c|c|c|c|c|c|}
\hline \multirow[b]{2}{*}{ Processos } & \multirow[b]{2}{*}{ Pontos críticos } & \multicolumn{4}{|c|}{ Índices } \\
\hline & & 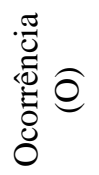 & 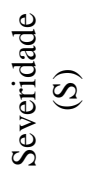 & 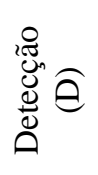 & 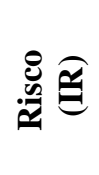 \\
\hline \multirow{5}{*}{ Montagem } & (P) Peças fora de esquadro & 3 & 3 & 4 & 36 \\
\hline & (Q) Ferragens colocadas em posição errada & 1 & 3 & 1 & 3 \\
\hline & (R) Rachadura em batentes & 3 & 3 & 5 & 45 \\
\hline & (S) Lixamento pouco preciso & 3 & 3 & 4 & 36 \\
\hline & (T) Peças sem encaixe preciso (com frestas) & 3 & 3 & 4 & 36 \\
\hline \multirow{5}{*}{ Projeto } & (U) Erros de medidas colhidas na obra & 2 & 4 & 3 & 24 \\
\hline & (V) Erros de desenho & 3 & 3 & 4 & 36 \\
\hline & (X) Erros de texto em projeto & 2 & 3 & 3 & 12 \\
\hline & (Y) Erro de dimensionamento de peças & 2 & 4 & 2 & 16 \\
\hline & (Z) Erro no cálculo para furar peças de granito & 3 & 4 & 5 & 60 \\
\hline
\end{tabular}

Para a atividade de secagem e armazenagem de madeira, os três pontos críticos analisados (A,B,C) apresentaram índice de ocorrência alto (ocorrência 4), o que indica alta a probabilidade de ocorrência das causas que dão origem às falhas. Para diminuir a ocorrência da causa é necessário promover melhorias no processo. Quanto a severidade os três pontos $(A, B, C)$ indicam que a falha é percebida pelo cliente e causa insatisfação (severidade 3). Quanto ao índice de detecção os três pontos críticos (A,B,C) apresentaram probabilidade média de observar a falha antes que ela chegue ao cliente (detecção 3). Para reduzir esse índice é necessário controlar o processo. O índice de risco prioriza os pontos críticos que devem ser trabalhados com maior urgência, sendo o primeiro item a ser gerenciado a perda de madeira $(C)(I R=48)$, seguido por grande quantidade de madeira descartada (A) (IR = 36) e madeira exposta ao tempo sem empilhar (B) $(I R=36)$. 
No pré-corte de batente e caixilho a probabilidade de ocorrência da causa que gera presença de defeitos na madeira (D) e grande quantidade de sobras (F) é analisada como alta (ocorrência 4); para retorno de peças com defeitos (E) é considerada moderada (ocorrência 3) e para estoque de madeira insuficiente na fábrica (G) é considerada baixa (ocorrência 2). Esse item tem ocorrência sazonal, porque a empresa trabalha com madeira originada da região norte do Brasil e em períodos de chuva o fornecedor enfrenta dificuldades para o baldeio e o transporte. O efeito que gera a grande quantidade de sobras (severidade 4) causa insatisfação do cliente interno (acionista) pelo baixo aproveitamento da matéria prima, mas não ao ponto de afetar sua segurança. Já os itens relativos à presença de defeitos na madeira (D) e estoque de madeira insuficiente na fábrica (G) (severidade 3) serão percebidos pelo cliente e causarão insatisfação. Para o retorno de peças com defeitos (severidade 2), o cliente perceberá a falha mas não ficará insatisfeito por causa dela. A probabilidade de observar as falhas referentes ao retorno de peças com defeitos (E) e grande quantidade de sobras (F) é considerada como baixa (detecção 4), não sendo percebida pelo cliente interno, embora seja um item de extrema importância, pois evidencia desperdício de material. Para presença de defeitos na madeira (D) e para estoque de madeira insuficiente na fábrica (G) as falhas apresentam probabilidade média de serem detectadas (detecção 3). De acordo com o estabelecimento de prioridades do índice de risco para a atividade de pré-corte de batente e caixilhos, o primeiro item a ser gerenciado é a grande quantidade de sobras $(F)(I R=64)$, seguido por presença de defeitos na madeira (D) $(I R=36)$, retorno de peças com defeitos $(E)(I R=24)$ e por estoque de madeira insuficiente na fábrica $(G)(I R=18)$. 
Para a atividade de beneficiamento, a probabilidade de ocorrência de erros na seleção da madeira (J), atrasos de pedidos (L) e montantes para veneziana fora de esquadro e rachados (I) é considerada alta (ocorrência 4) e para erros de medida (H) é considerada moderada (ocorrência 3). O índice de severidade para os quatro pontos (H,I,J,L) analisados indicam que a falha é percebida pelo cliente e causa insatisfação (severidade 3). O índice de detecção para erros na seleção da madeira (J) e montante de veneziana fora de esquadro e rachados (I) apresentam probabilidade média em relação a falha ser observada antes de chegar ao cliente (detecção 3); para que este índice seja reduzido é necessário controlar o processo. Para os itens erros de medida (H) e atrasos de pedido (L) a probabilidade da falha ser detectada é considerada muito alta (detecção 1) e para reduzir a falha é necessário que sejam feitas alterações no processo. Os primeiros pontos críticos a serem gerenciados com ações corretivas durante o beneficiamento, segundo o índice de risco são: os erros na seleção da madeira (J) (IR = 36), seguido por montantes para veneziana fora de esquadro e com rachaduras (I) (IR = 36), atraso de pedidos $(\mathrm{L})(\mathrm{IR}=12)$ e erros de medidas $(\mathrm{H})(\mathrm{IR}=9)$.

Para a pintura, a probabilidade de ocorrência da causa que gera pouco espaço para manuseio de peça (M) e o alto consumo de tinta é analisada como alta (ocorrência 4) e para a falta de agilidade no processo de pintura é considerada moderada (ocorrência 3). 
O efeito gerado pela falta de agilidade no processo de pintura (N) (severidade 4) causa insatisfação do cliente mas não a ponto de afetar sua segurança, já o item pouco espaço para o manuseio de peças (M) (severidade 3) é percebido pelo cliente e causa sua insatisfação. Para o elevado consumo de tinta $(\mathrm{O})$ (severidade 1), o cliente não perceberá a falha. A probabilidade de observar falhas nos itens pouco espaço para manuseio de peças (M) e falta de agilidade no processo de pintura (N) é considerada alta (detecção 2), e para o consumo de tinta $(\mathrm{O})$, a probabilidade de detectar é média (detecção 3). De acordo com as prioridades estabelecidas pelo índice de risco, os primeiros itens a serem gerenciados são o pouco espaço para manuseio de peças $(M)(I R=24)$ e falta de agilidade no processo de pintura $(\mathrm{N})(\mathrm{IR}=24)$, seguido pelo alto consumo de tinta $(\mathrm{O})$ $(\mathrm{IR}=12)$.

A montagem aponta falhas que são originadas em outras etapas do processo, como é o caso de quase todos os itens levantados. Apenas os itens rachadura de batentes (R) e colocação de ferragens em posição errada (Q) são originados no desenvolvimento da montagem em si. Essa etapa do processo funciona como sinalizador das falhas da produção e poderia vir a ser a responsável pelo controle de qualidade, já que os funcionários que desenvolvem essa atividade necessitam imaginar as peças nos vãos de parede antes de serem confeccionadas, analisando como fazê-las e evitando assim erros de projeto.

Para a montagem a probabilidade de ocorrência de peças fora de esquadro (P) lixamento pouco preciso $(\mathrm{S})$, rachadura de batentes $(\mathrm{R})$ e peças sem encaixe preciso $(\mathrm{T})$ 
são consideradas moderadas (ocorrência 3) e baixa (ocorrência 1) para ferragens colocadas em posição errada (Q). Quanto ao índice de severidade, todos os itens analisados (P,Q,R,S,T) apresentaram índice igual a 3, o que indica que os pontos críticos serão percebidos pelo cliente e causarão sua insatisfação. A probabilidade de observar falhas nos itens lixamento pouco preciso das peças (S), peças fora de esquadro (P) e sem encaixe preciso (T) é considerada como baixa (detecção 4). Para o item rachadura em batentes (R) (detecção 5) a probabilidade de detectar a falha antes de chegar ao cliente é considerada muito baixa e para o item ferragens colocadas em posição errada (Q) (detecção 1), a falha possui uma probabilidade muito alta de ser detectada. De acordo com o estabelecimento de prioridades do índice de risco, o primeiro item a ter ações corretivas realizadas é rachadura em batentes $(R)(I R=45)$, seguido por peças sem encaixe preciso $(T)(I R=36)$, lixamento pouco preciso $(S)(I R=36)$, peças fora de esquadro (P) (IR = 36) e ferragens colocadas em posição errada (Q) (IR = 3).

Para a atividade de projetos a probabilidade de ocorrência de erros de desenho (V) e no cálculo da furação das peças de granito (Z) é considerada moderada (ocorrência 3). Para os itens erros de medidas colhidas na obra (U), erros de texto no projeto (X) e erros de dimensionamento de peças (Y) (ocorrência 2) é considerada baixa. O índice de severidade para erros no planejamento dos furos para as peças de granito (Z), erros de dimensionamento das peças (Y) e erros de medidas colhidas na obra (U) (severidade 4) indicam que o cliente ficará insatisfeito se estas falhas ocorrem, mas elas não afetarão a segurança do cliente. Para os itens erro de desenho e de texto no projeto, a falha é percebida pelo cliente e causa insatisfação (severidade 3). Os efeitos que as falhas 
analisadas causam nesta atividade causam insatisfação e atingem diretamente o cliente interno e externo da empresa, prejudicando a credibilidade e confiança no produto.

O índice de detecção para o erro no planejamento dos furos das peças de granito (Z) apresenta probabilidade muito baixa da falha ser detectada e observada antes de chegar ao cliente (detecção 5). Para o item erros de desenho (V) (detecção 4), a probabilidade de detectar a falha é baixa. Para os itens erros de texto no projeto (X) e erros de medidas colhidas na obra (U) (detecção 3), a probabilidade de detectar a falha é analisada como média. Já para o item erro de dimensionamento de peças de granito (Y) (detecção 2), a probabilidade de detectar a falha ao longo do processo antes que ela chegue ao cliente é considerada alta. Para reduzir essa falha é necessário que sejam feitas alterações nos processos, estabelecendo rotinas padrões de conferência de projeto antes que as peças sejam produzidas.

De acordo com a prioridade estabelecida pelo índice de risco, os erros a serem trabalhados com o desenvolvimento de ações corretivas são os de planejamento dos furos das peças de granito $(\mathrm{Z})(\mathrm{IR}=60)$, seguido por erros de desenho (V) $(\mathrm{IR}=36)$, medida na obra $(\mathrm{U})(\mathrm{IR}=24)$, erros de dimensionamento de peças de granito $(\mathrm{Y})$ ( IR = 16) e de texto no projeto $(X)(I R=12)$. 


\subsection{Estudo das causas dos pontos críticos}

\subsubsection{Secagem e armazenagem de madeira}

A partir da aplicação do FMEA os pontos críticos apontados como prioritários no índice de risco para desenvolvimento de medidas de ação corretiva são: a perda de madeira, grande quantidade de madeira descartada e madeira exposta ao tempo empilhadas sem utilização de tabiques.

\subsubsection{Perda de madeira no processo de secagem e armazenagem}

O estudo da causa de perda de madeira no depósito destacou como possíveis causas: a mistura de espécies para realização da secagem, o não monitoramento da umidade ao longo do processo, pilhas mal feitas, a madeira comprada de má qualidade e falta de treinamento. A Figura 14 ilustra o diagrama de causa e efeito referente à perda de madeira. 


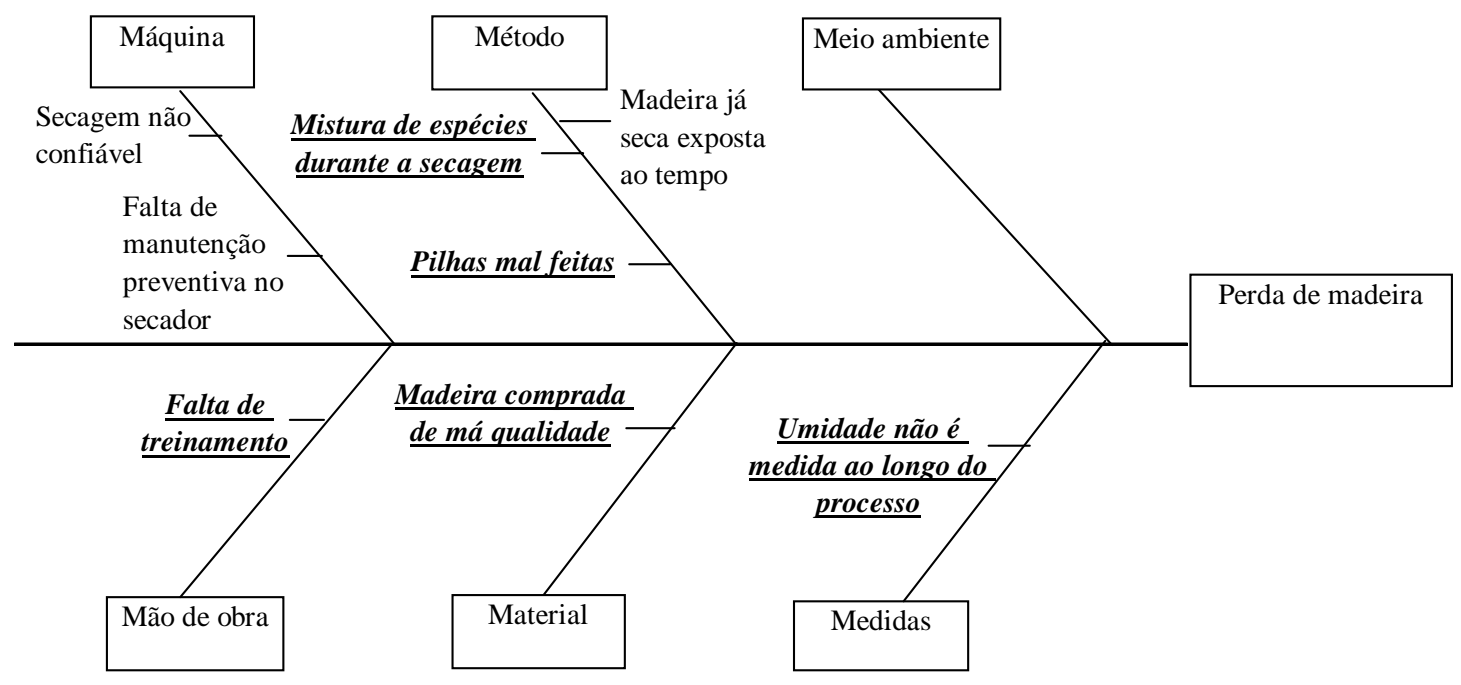

Figura 14 - Diagrama de Ishikawa para perda de madeira na atividade de secagem e armazenagem de madeira

A mistura de espécies para secagem é prejudicial, pois cada uma possui características diferentes necessitando de programas apropriados, caso contrário, a secagem pode resultar em tensões, proporcionando trincas que contribuirão para o aumento das perdas de matéria-prima.

O item umidade, não determinada ao longo do processo, está diretamente ligado ao monitoramento do processo de secagem e avaliação de sua qualidade. Sua importância é fundamental visando prevenir empenamentos e perdas de peças já 
beneficiadas. A qualidade da madeira comprada é um item sujeito às oscilações ao longo do ano, sendo fortemente influenciada pelas expectativas de demanda do mercado externo que condiciona a oferta ou escassez de madeira de boa qualidade para o mercado interno.

O empilhamento de madeira mal feito pode causar incidência de defeitos como empenamentos e tortuosidades nas pranchas. Este item está diretamente ligado a falta de treinamento que é agravado nessa empresa porque essa atividade é realizada por diaristas sem experiência no manuseio da madeira.

\subsubsection{Quantidade de madeira descartada na secagem e armazenagem}

Para o estudo da causa grande quantidade de madeira descartada a equipe apontou como as prováveis fatores: a falta de treinamento para cortar a madeira com maior aproveitamento, madeira de baixa qualidade e produção sem padrão definido. A Figura 15 ilustra o Diagrama de Ishikawa para elaborado para o estudo dessa causa. 


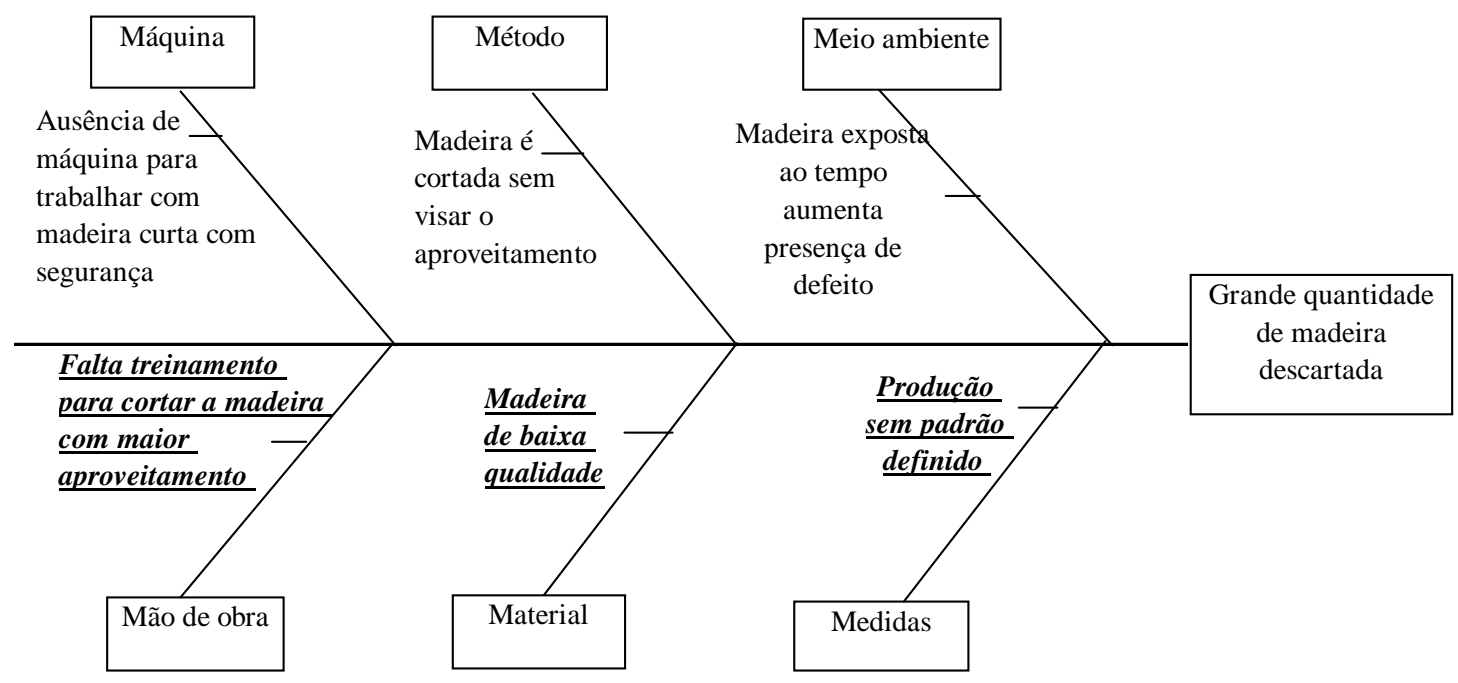

Figura 15 - Diagrama de Ishikawa para a grande quantidade de madeira descartada na secagem e armazenagem de madeira

O desenvolvimento do trabalho na empresa caracteriza-se pelo emprego de mãode-obra pouco especializada e as atividades são desenvolvidas com base na experiência profissional e prática de cada funcionário, utilizando como forma de treinamento a troca de conhecimento entre os que dominam os processos e os que acabaram de entrar na empresa. A falta de treinamento é um dos fatores que necessitam ser trabalhados continuamente em todas as áreas e atividades desenvolvidas e há necessidade de criar um programa de treinamento ou reciclagem.

A madeira de baixa qualidade é uma conseqüência das causas discutidas na item anterior (Figura 14). Itens como a perda de madeira e a produção sem padrão definido 
são apontados como causas potenciais, mas esse último faz parte do foco de negócio da empresa.

\subsubsection{Madeira exposta ao tempo na secagem e armazenagem}

Para o item madeira exposta ao tempo empilhada sem uso de tabiques as causas potenciais identificadas são: falta de veículo para transporte da madeira até uma base de apoio (espécie de “mureta” feita de tijolos e cimento, para erguer as pilhas de madeira do solo visando garantir uma melhor qualidade no empilhamento); planejamento ineficiente para entrada da madeira para secagem artificial e mão-de-obra pouco qualificada para empilhar a madeira. A Figura 16 apresenta o Diagrama de Ishikawa e as causas potenciais para o item madeira exposta ao tempo empilhada sem utilizar tabiques. 


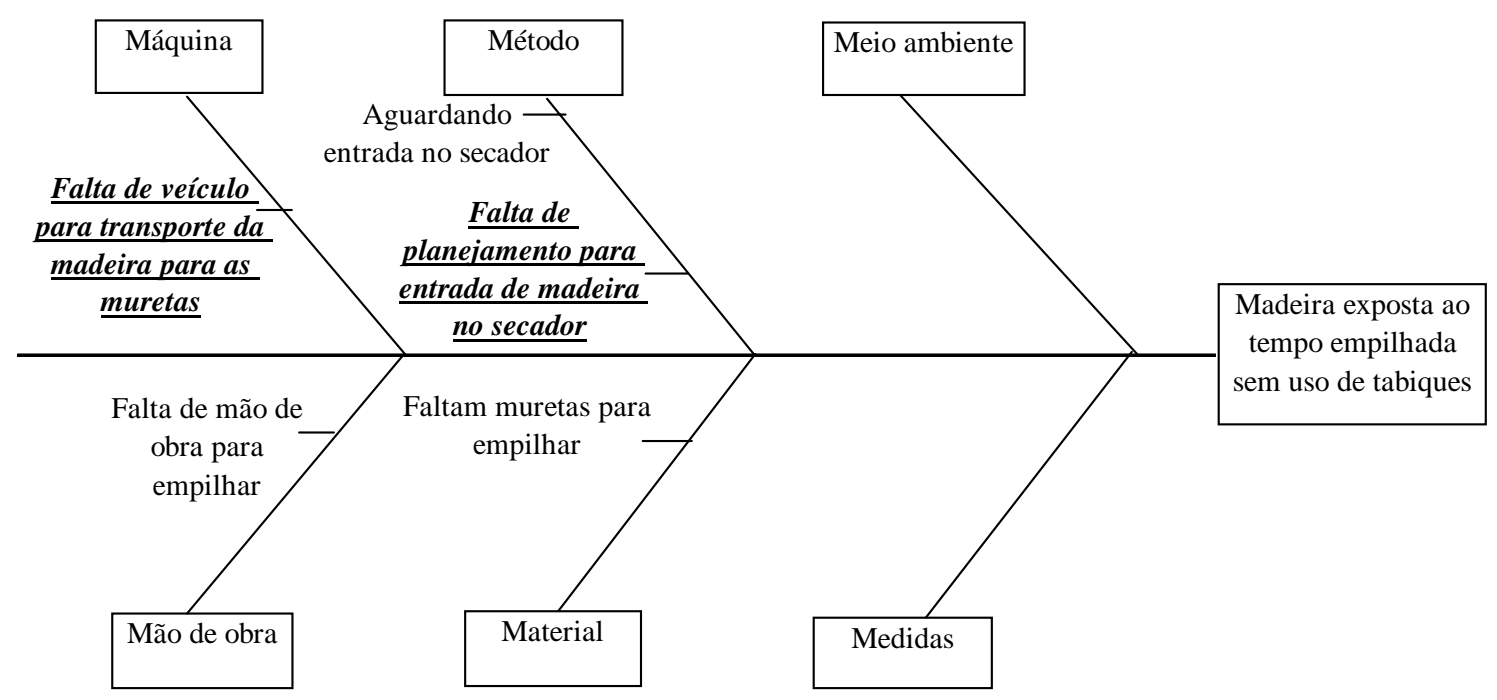

Figura 16 - Diagrama de Ishikawa para madeira exposta ao tempo sem uso de tabiques no empilhamento para a secagem e armazenagem de madeira

A causa falta de veículo para transporte foi apontada como potencial porque a empresa possui apenas um caminhão que realiza entrega de produtos acabados, desloca a madeira no depósito e também a transposta para a fábrica. A atividade de entrega de produtos tem prioridade na utilização do caminhão enquanto que as outras acabam ficando em segundo plano. Dessa forma há um acúmulo de madeira para ser empilhada no pátio pois o uso do caminhão é indispensável para movimentar a madeira. Essa situação se agrava quando as cargas compradas são entregues ao mesmo tempo pelos fornecedores e se acumulam no local de descarga e chegam a permanecer sem empilhar durante meses. A madeira que permanece amontoada sem empilhar está sujeita a apresentar mais defeitos (tortuosidades, trincas, etc.) do que a empilhada de forma 
adequada e além disso, quando a madeira está empilhada pode perder umidade pela secagem ao ar, podendo assim reduzir o tempo na secagem artificial.

\subsubsection{Pré -corte de batente e caixilho}

Para o pré-corte de batente e caixilho, os pontos críticos apontados pelo índice de risco do FMEA para desenvolvimento de ações corretivas são: a grande quantidade de sobras, presença de defeitos na madeira e retorno de peças com defeitos.

\subsubsection{Sobras de madeira no pré-corte de batente e caixilho}

A grande quantidade de sobras, classificado com índice de risco 64 ilustrada no Diagrama de Ishikawa da Figura 17, pode estar relacionada com o tipo do processo produtivo “sob encomenda” e por não haver medidas padronizadas para a fabricação das peças projetadas, o que gera um menor aproveitamento das pranchas. A falta de treinamento para selecionar e processar a madeira contribui para aumento de perdas, pois se a madeira for utilizada visando a análise da seqüência de corte com ênfase no aproveitamento, a matéria-prima pode ter um aproveitamento maior. A falta de separação das pranchas por tamanho no estoque está diretamente ligada a agilidade na seleção da melhor prancha, quanto mais separado e organizado o estoque melhor a visualização e escolha das pranchas. A Figura 17 ilustra o estudo da causa para a grande quantidade de sobras no pré-corte de caixilho e batentes. 


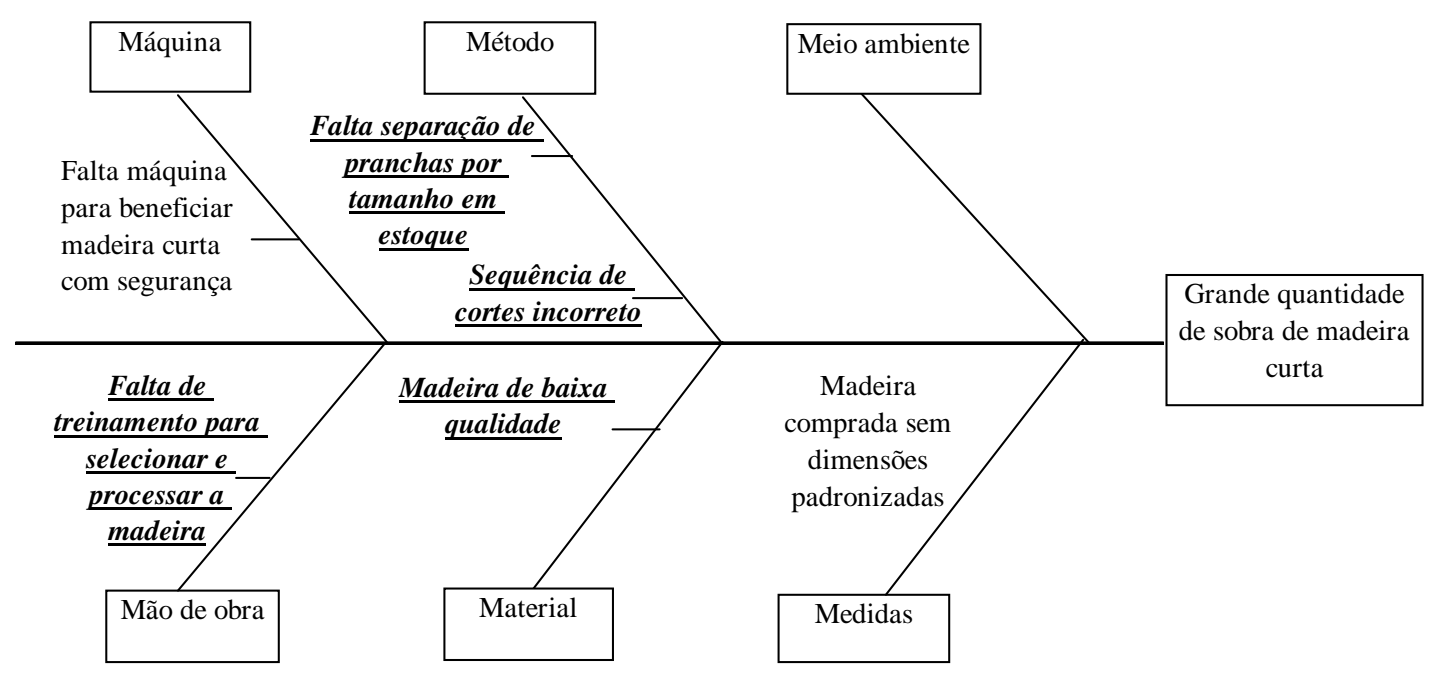

Figura 17 - Diagrama de Ishikawa para a quantidade de sobra de madeira curta durante a atividade de pré corte de batente e caixilho

\subsubsection{Presença de defeitos no pré-corte de batente e caixilho}

Com relação a presença de defeitos, classificado pelo índice de risco 36 e analisado no Diagrama de Ishikawa ilustrado na Figura 18, a principal causa apontada como responsável pela ocorrência é a dificuldade de encontrar madeira de qualidade para compra que está ligada ao estabelecimento da relação cliente-fornecedor, na sazonalidade do mercado externo e no gerenciamento das atividades de secagem e armazenagem discutidos no item perda de madeira. Como pode ser observado as falhas quando não resolvidas sempre irão interferir nas atividades seqüenciais de forma direta (como por exemplo, perdas de madeira, tempo operacional, custos entre outros). 


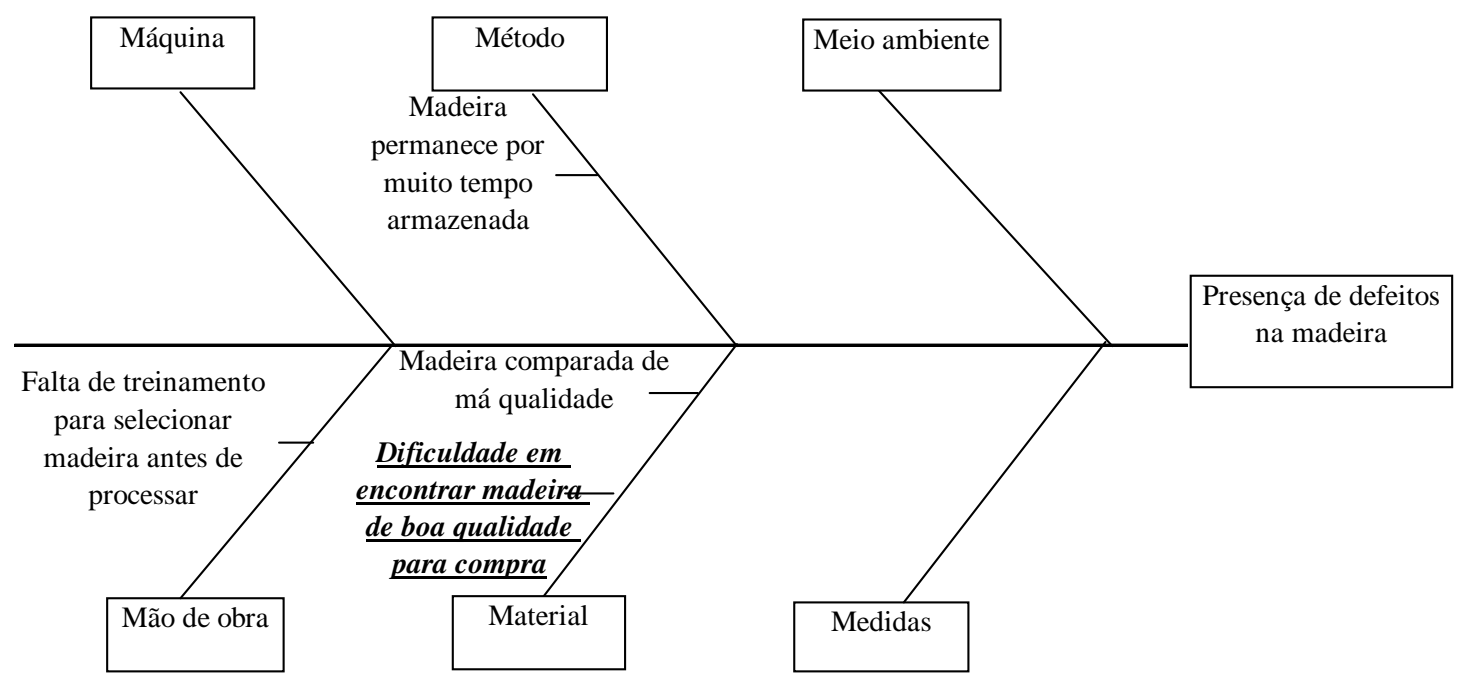

Figura 18 - Diagrama de Ishikawa para a presença de defeito na madeira durante a atividade de pré corte

\subsubsection{Beneficiamento}

Para as atividades de beneficiamento da madeira, os itens críticos apontados pelo FMEA foram os erros na seleção da madeira (índice de risco 36) e os montantes para veneziana fora de esquadro e rachados (índice de risco 36).

\subsubsection{Seleção da madeira no beneficiamento}

Os erros na seleção da madeira durante o beneficiamento estão ligados ao gerenciamento da rotina: falta de estabelecimento de procedimentos operacionais e 
treinamentos para seleção da madeira. Esse tipo de erro pode ocorrer porque a empresa vende o produto com dois tipos de pintura: fundo para aplicação de verniz e para branco ou cores. As madeiras selecionadas para verniz não podem apresentar nenhum tipo de imperfeição, mas para pintura podem apresentar variações na tonalidade e pequenas imperfeições. A Figura 19 ilustra as causas que podem originar esse erro.

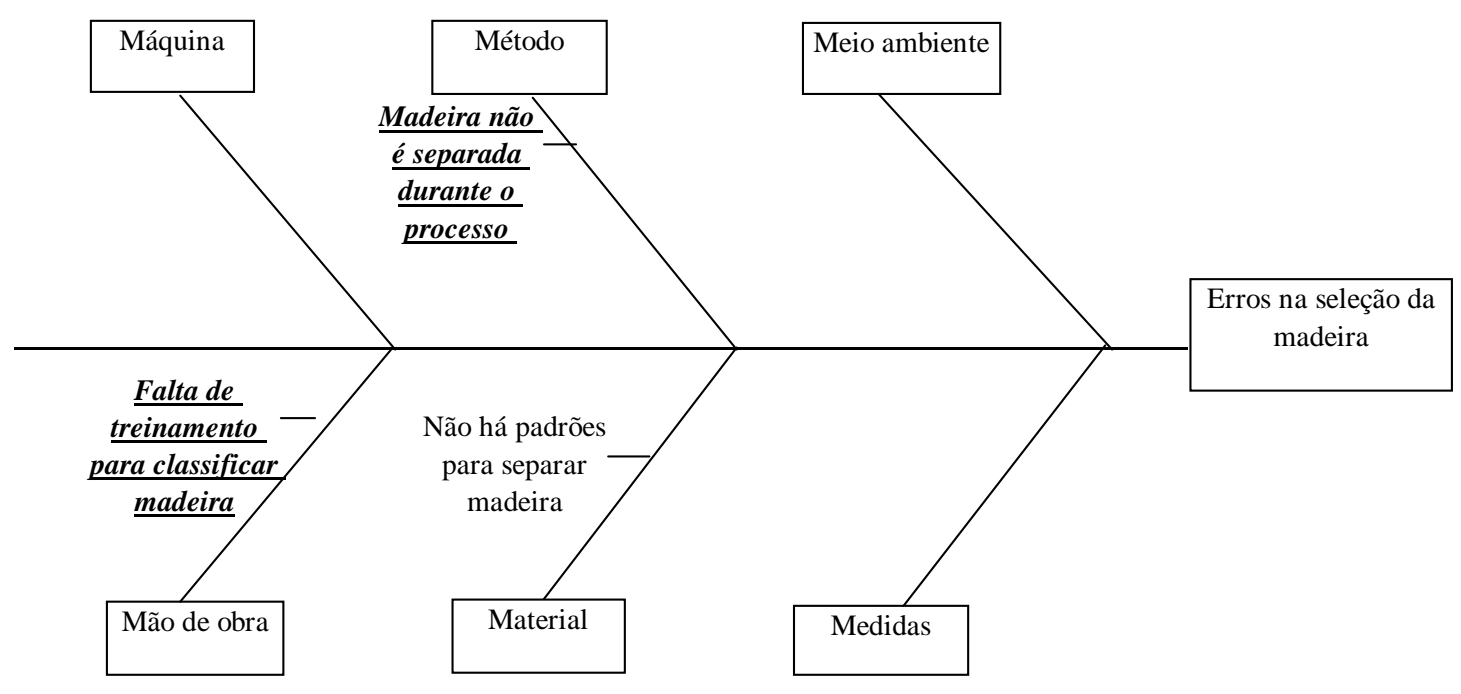

Figura 19 - Diagrama de Ishikawa para defeito na seleção da madeira durante o beneficiamento

\subsubsection{Montantes fora de esquadro no beneficiamento}

Com relação a montantes fora de esquadro os itens considerados críticos são máquina regulada sem precisão e fresa sem afiar. Esses itens podem ser corrigidos com 
controle de manutenção individual para cada máquina e treinamento para o operador. A Figura 20 ilustra as causas prováveis para a ocorrência desse defeito.

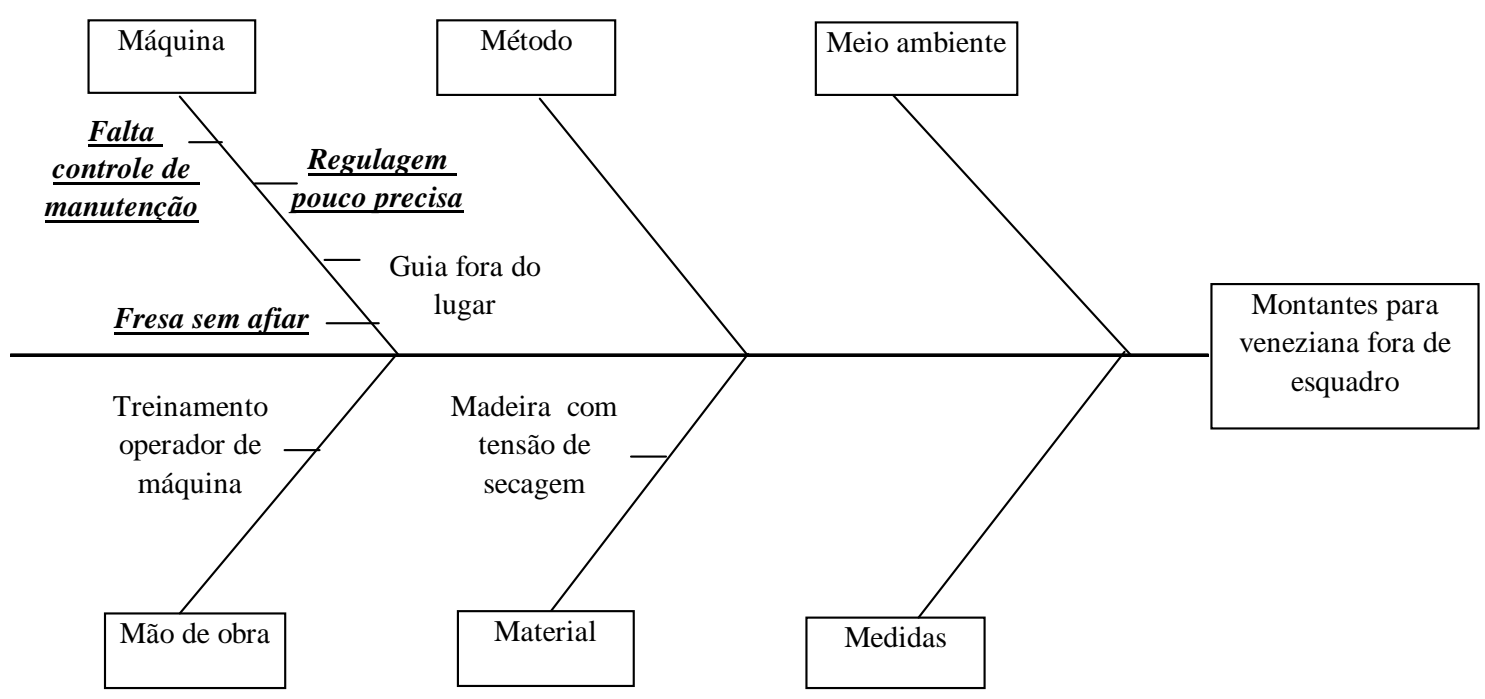

Figura 20 - Diagrama de Ishikawa para montantes fora de esquadro na atividade de beneficiamento

\subsubsection{Pintura}

Quanto a atividade de pintura os itens críticos indicados pelo FMEA são: o pouco espaço para o manuseio de peças (índice de risco 24) e a falta de agilidade no processo de pintura (índice de risco 24). 


\subsubsection{Agilidade e espaço disponível para pintura}

Com relação a falta de agilidade no processo de pintura, a principal causa é a demora na troca de peças que é uma conseqüência das pequenas dimensões da cabine de pintura, sendo uma causa que pode ser classificada como estrutural da empresa. E o mesmo ocorre com o próximo item apontado pelo FMEA, pouco espaço para manuseio de peças. O estudo das causas não foi realizado já que a ação corretiva requer investimento financeiro. A Figura 21 ilustra o Diagrama de Ishikawa para a falta de agilidade no processo de pintura.

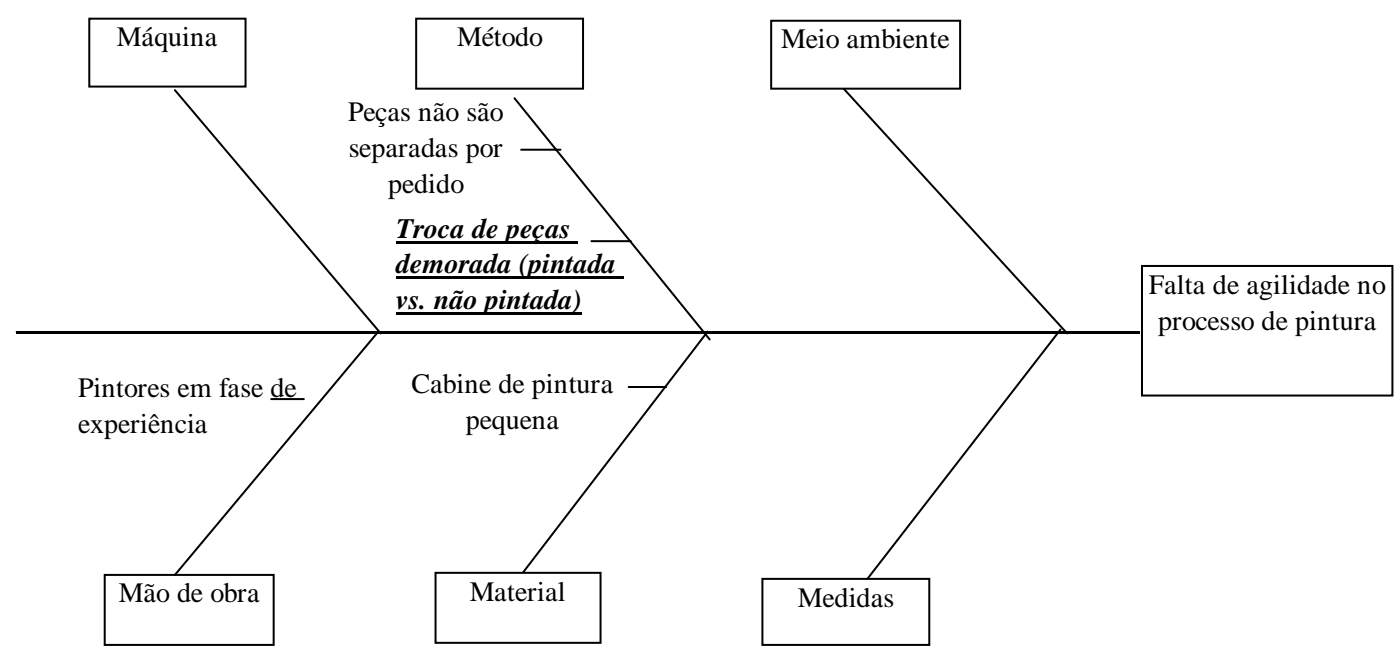

Figura 21 - Diagrama de Ishikawa para falta de agilidade no processo de pintura 


\subsubsection{Montagem}

Para a montagem, os pontos críticos apontados pelo FMEA são: a rachadura em batentes (índice de risco 45), peças sem encaixe preciso, com frestas (índice de risco 36), lixamento pouco preciso (índice de risco 36) e peças fora de esquadro (índice de risco 36).

\subsubsection{Rachaduras na montagem}

A causa para a rachadura em batentes é atribuída ao uso de pregos para junção das peças. Como essa foi a única causa encontrada e a única sugerida, torna-se desnecessário representá-la através do Diagrama de Ishikawa.

\subsubsection{Aparecimento de frestas durante a montagem}

Para o item peças sem encaixe preciso (com frestas), as causas diagnosticadas como principais foram: máquina com defeito, falta de fresa e treinamento do operador. Esse item é de fundamental importância por afetar diretamente o cliente através da qualidade do produto. A máquina utilizada para fazer os encaixes apresentava defeito na regulagem que não se mantinha precisa até o término do processo. O operador necessita de treinamento para desenvolver o hábito de conferir as condições da máquina, regulagens e controlar o processo utilizando por exemplo gráficos de controle. A Figura 22 ilustra o estudo dessa causa. 


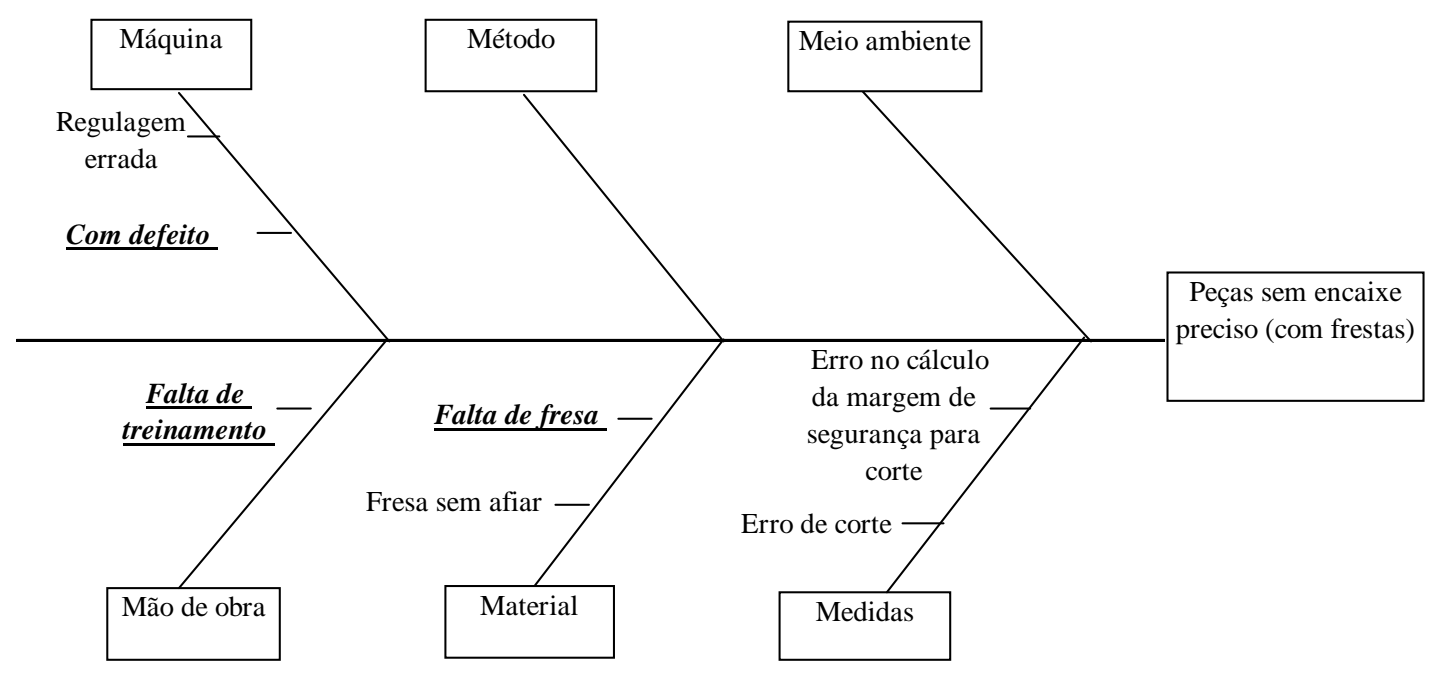

Figura 22 - Diagrama de Ishikawa para peças sem encaixe preciso

\subsubsection{Qualidade do lixamento das peças na montagem}

Para o item lixamento pouco preciso, atividade desenvolvida na durante a atividade de beneficiamento, a causa apontada como mais provável refere-se ao emprego de uma seqüência de lixas de espessuras inadequadas; o estudo das causas pode ser visto na Figura 23. O lixamento pouco preciso ocorre pelo uso de lixas grossas demais durante a seqüência de passagem de lixas causando assim um mal acabamento das peças. 


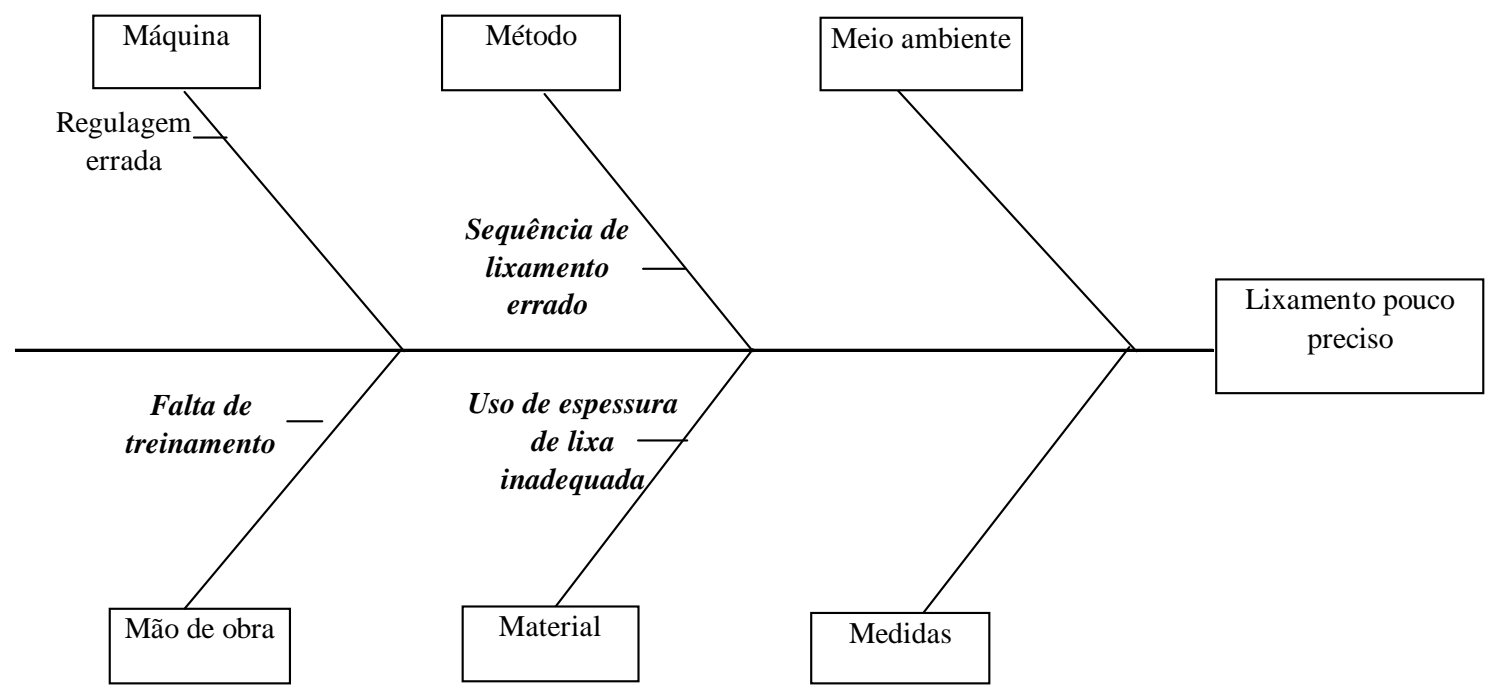

Figura 23 - Diagrama Ishikawa para lixamento pouco preciso

\subsubsection{Aparecimento de peças tortas na montagem}

Para o item peças fora de esquadro (tortas) foram identificadas as seguintes causas potenciais: seqüência de corte errado e falta de treinamento do operador. A análise das causas é ilustrada na Figura 24. 


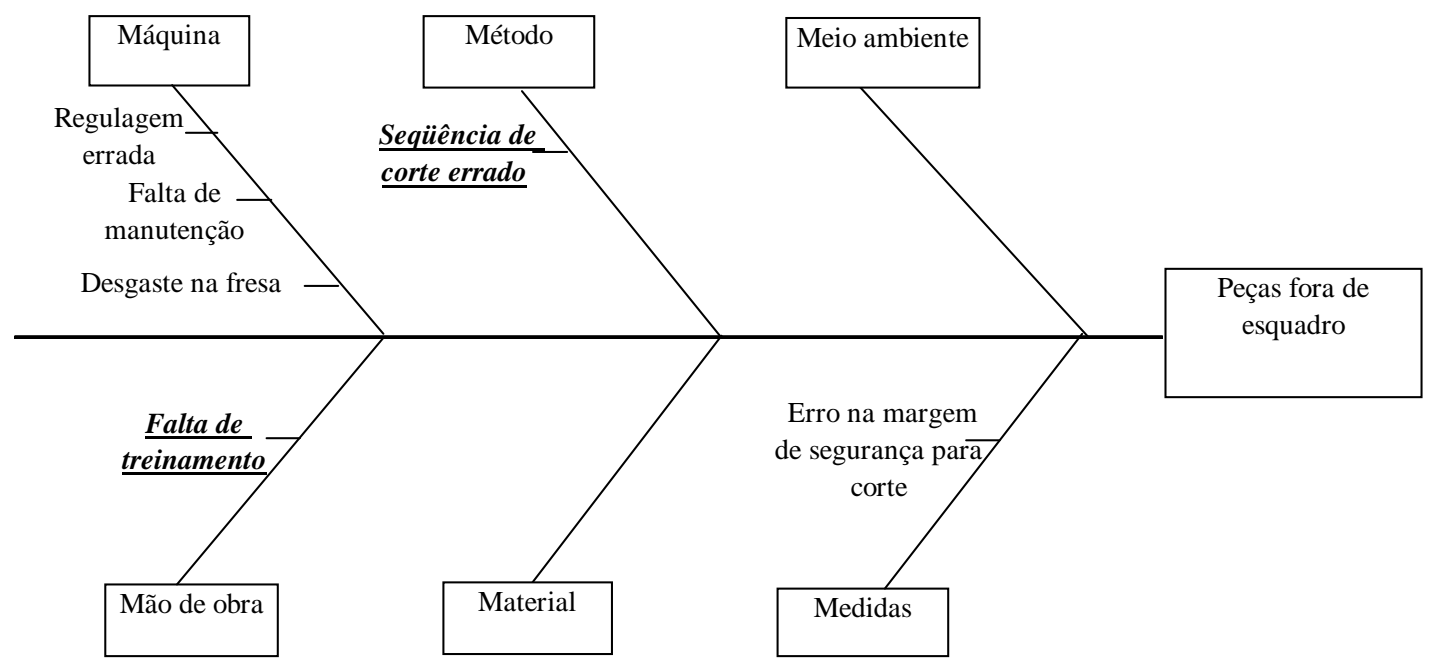

Figura 24 - Diagrama Ishikawa para peças fora de esquadro na montagem

A máquina que opera nesse processo é uma respigadeira multifuncional que realiza uma seqüência de cortes em cada peça. Ao término do segundo corte o produto retorna para a fase inicial e acaba realizando um corte involuntário que gera um desgaste milimétrico na peças. Esse desgaste pode ser responsável pela diferença de medidas que geram a peça fora de esquadro. É necessário que seja feita uma avaliação na máquina por um técnico especializado para avaliar essa causa é válida e se operador está realizando a atividade corretamente. 


\subsection{Projetos}

Para a atividade de projetos, os itens críticos apontados pelo FMEA foram os erros no planejamento da furação em peças de granito (índice de risco 60), erros de desenho (índice de risco 36), erros de medidas colhida na obra (índice de risco 24).

Para os erros analisados no projeto não foi possível elaborar diagramas de causa e efeito, pois segundo os funcionários responsáveis, estes ocorrem devido a grande quantidade de material desenhado e projetado.

\subsection{Medidas de desempenho}

\subsubsection{Secagem e armazenagem de madeira}

Os itens críticos referentes a perda e a grande quantidade de madeira descartada estão relacionados com: qualidade da madeira comprada, atividades de secagem e manuseio da madeira no pátio. Os indicadores foram desenvolvidos visando monitorar esses pontos considerados fundamentais.

Como a empresa é de pequeno porte, a compra de madeira exige muita negociação, principalmente quanto ao prazo de entrega, qualidade e quantidade da madeira. Para monitorar e analisar o item qualidade da madeira comprada, dois pontos são considerados importantes: a compra da madeira (a negociação em si) e o fornecedor (fidelização ao pedido e cumprimento da negociação). O fornecedor é analisado com os 
indicadores: entregas feitas no prazo (\%), qualidade de carga (atribuição de uma nota de 0 a 10 para a qualidade da madeira entregue), quantidade da carga, dimensões e formas de pagamento estabelecidos na nota. Para cada carga entregue é preenchido uma folha de verificação contendo a negociação da compra de madeira e as características qualitativas e quantitativas da carga de madeira. A Figura 25 mostra esquematicamente os indicadores relacionados a atividade de descarga de madeira visando a análise do fornecedor e a Tabela 7 apresenta o resultado da aplicação dos indicadores.

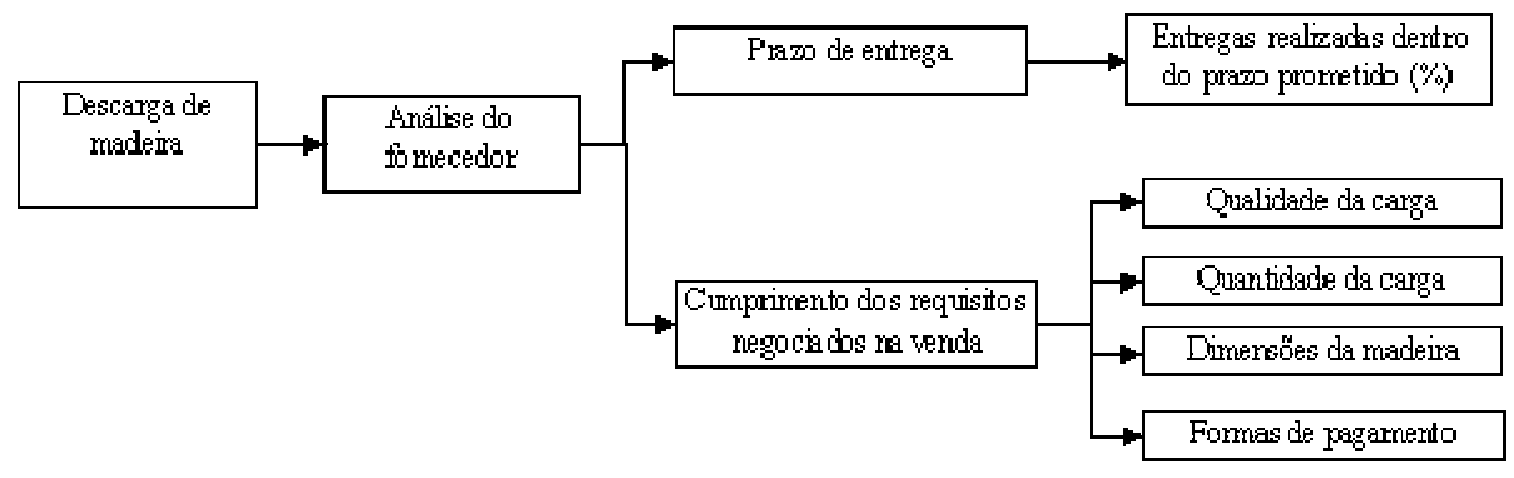

Figura 25 - Indicadores de análise do fornecedor de madeira 
Tabela 7. Avaliação geral dos fornecedores

\begin{tabular}{cccccc}
\hline Fornecedores & $\begin{array}{c}\text { Recebimento } \\
\text { de madeira }\end{array}$ & $\begin{array}{c}\text { Qualidade } \\
\text { da carga } \\
\text { (nota 0 a 10, } \\
\text { em valores } \\
\text { médios) }\end{array}$ & $\begin{array}{c}\text { Quantidade } \\
\text { da carga } \\
\text { (valores } \\
\text { médios) }\end{array}$ & $\begin{array}{c}\text { Dimensões } \\
\text { da madeira } \\
\text { (valores } \\
\text { médios) }\end{array}$ & $\begin{array}{c}\text { Forma de } \\
\text { pagamento } \\
\text { (valores } \\
\text { médios) }\end{array}$ \\
\hline 1 & 8 & 8 & $\begin{array}{c}75 \% \\
\text { Conforme } \\
80 \%\end{array}$ & $\begin{array}{c}100 \% \\
\text { Conforme } \\
100 \%\end{array}$ & $\begin{array}{c}\text { Conforme } \\
\text { Conforme } \\
84 \%\end{array}$ \\
3 & 5 & 7 & $\begin{array}{c}800 \% \\
\text { Conforme } \\
100 \%\end{array}$ & $\begin{array}{c}\text { Conforme } \\
100 \%\end{array}$ \\
Conforme & Conforme \\
\hline
\end{tabular}

$\mathrm{Na}$ avaliação de fornecedores o item considerado crítico é a quantidade apresentando de 75 a 84\% de carga entregue de acordo com o pedido realizado. Isso pode ter ocorrido em algumas cargas que foram compradas em quantidade pequenas, não chegam a completar um caminhão, e o fornecedor encaminha vários pedidos de diferentes empresas para aproveitar o transporte.

Para o gerenciamento do pátio de madeira, os itens passíveis de monitoramento são o controle de estoque, controle de perdas e a qualidade da madeira após a secagem. E a Figura 26 mostra os indicadores considerados importantes para esse processo. 


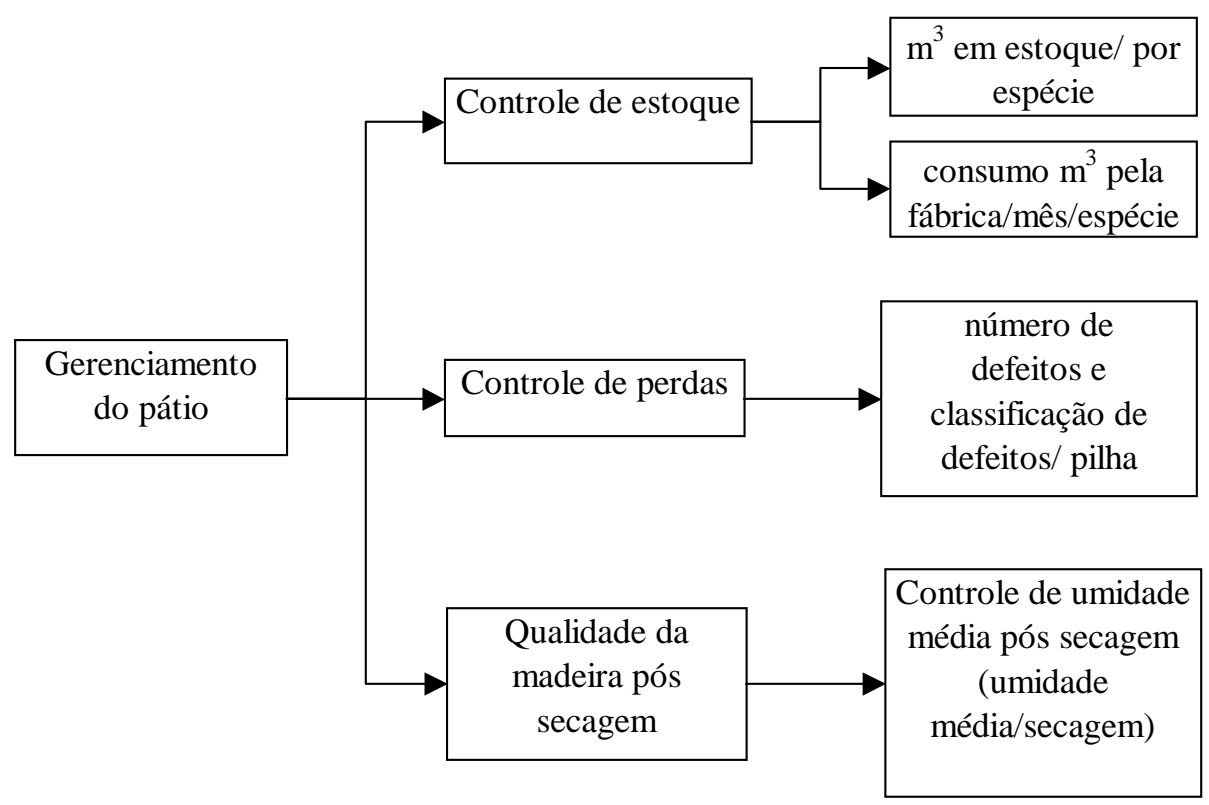

Figura 26 - Indicadores de gerenciamento do pátio de madeira

O controle de estoque associado ao consumo mensal, para a empresa em questão, gira em torno de trinta e sete metros cúbicos mensais ( $37 \mathrm{~m}^{3} / \mathrm{mês}$ ) e essa informação é essencial para o planejamento de compra de madeira. A Figura 27 ilustra o estoque de madeira disponível por espécie. 


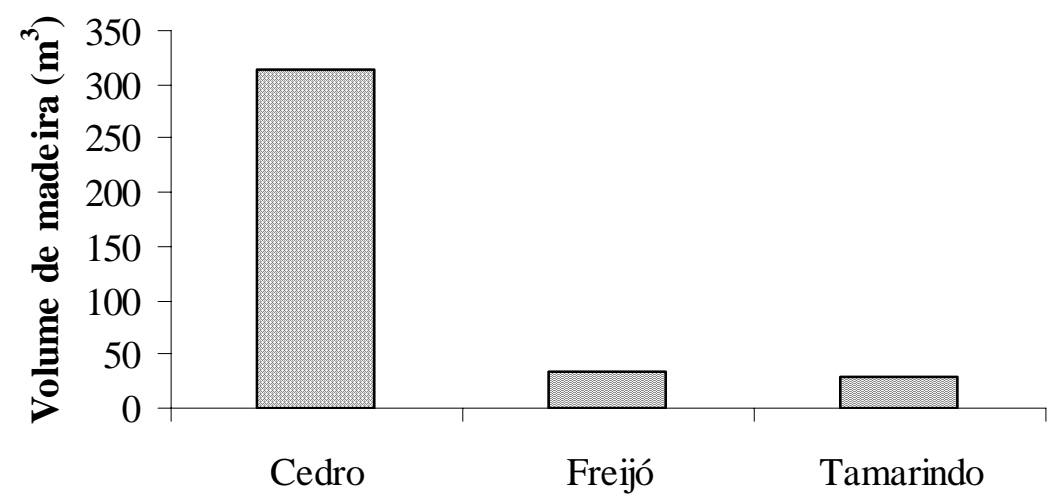

Figura 27 - Volume de madeira $\left(\mathrm{m}^{3}\right)$ em estoque/espécie

A avaliação do empilhamento, quantidade de espaços vazios entre as tábuas, posição, uniformidade e distribuição dos separadores entre as pranchas em cada pilha são feitas seguindo a classificação péssimo (1), ruim (2), médio (3), bom (4) e ótimo (5). Outro item importante que deve ser constantemente observado é a infestação de insetos, sendo que essa avaliação foi realizada visualmente, seguindo os critérios ausente (1), baixa (2), média (3), alta (4) e muito alta (5). A Tabela 8 ilustra o resultado da avaliação da madeira empilhada no pátio, os índices foram obtidos utilizando a escala de Likert (1 a 5). 
Tabela 8. Avaliação da madeira empilhada no pátio

\begin{tabular}{cccccccccc}
\hline \multirow{2}{*}{$\begin{array}{c}\text { Pilha de madeira } \\
\text { Número }\end{array}$} & \multicolumn{2}{c}{ Espaços vazios } & \multicolumn{2}{c}{$\begin{array}{c}\text { Posição, uniformidade e } \\
\text { distribuição de separadores }\end{array}$} & \multicolumn{2}{c}{ Infestção de insetos } & \multicolumn{2}{c}{ Classificação geral da pilha } & Índice Geral \\
& Classificação Índice & Classificação & Índice & Classificação & Índice & Classificação & Índice & \\
\hline 1 & Bom & 4 & Ruim & 2 & Baixa & 2 & Média & 3 & 11 \\
2 & Ruim & 2 & Ruim & 2 & Ausente & 1 & Ruim & 2 & 7 \\
3 & Bom & 4 & Bom & 4 & Ausente & 1 & Bom & 4 & 13 \\
4 & Ruim & 2 & Médio & 3 & Ausente & 1 & Média & 3 & 9 \\
5 & Bom & 4 & Ruim & 2 & Ausente & 1 & Média & 3 & 10 \\
6 & Bom & 4 & Ruim & 2 & Ausente & 1 & Média & 3 & 10 \\
7 & Ruim & 2 & Ruim & 2 & Baixa & 2 & Ruim & 2 & 8 \\
8 & Ótimo & 5 & Bom & 4 & Ausente & 1 & Ótimo & 5 & 15 \\
9 & Médio & 3 & Médio & 3 & Ausente & 1 & Média & 3 & 10 \\
10 & Ruim & 2 & Ruim & 2 & Ausente & 1 & Ruim & 2 & 7 \\
11 & Médio & 3 & Ruim & 2 & Baixa & 2 & Ruim & 2 & 9 \\
12 & Ruim & 2 & Ruim & 2 & Ausente & 1 & Ruim & 2 & 7 \\
13 & Ruim & 2 & Ruim & 2 & Ausente & 1 & Ruim & 2 & 7 \\
14 & Ruim & 2 & Ruim & 2 & Baixa & 2 & Ruim & 2 & 8 \\
15 & Médio & 3 & Médio & 3 & Ausente & 1 & Média & 3 & 10 \\
\hline
\end{tabular}

Outro fator importante é a secagem da madeira que quando realizada de forma adequada previne aparecimento de defeitos e tensões. Visando a padronização dessa importante atividade recomenda-se a criação de um procedimento operacional, um documento oficial da empresa, que visa assegurar que a secagem seja feita sempre da mesma forma visando padronizar o método. A Figura 28 ilustra as principais informações técnicas que devem constar neste procedimento. 


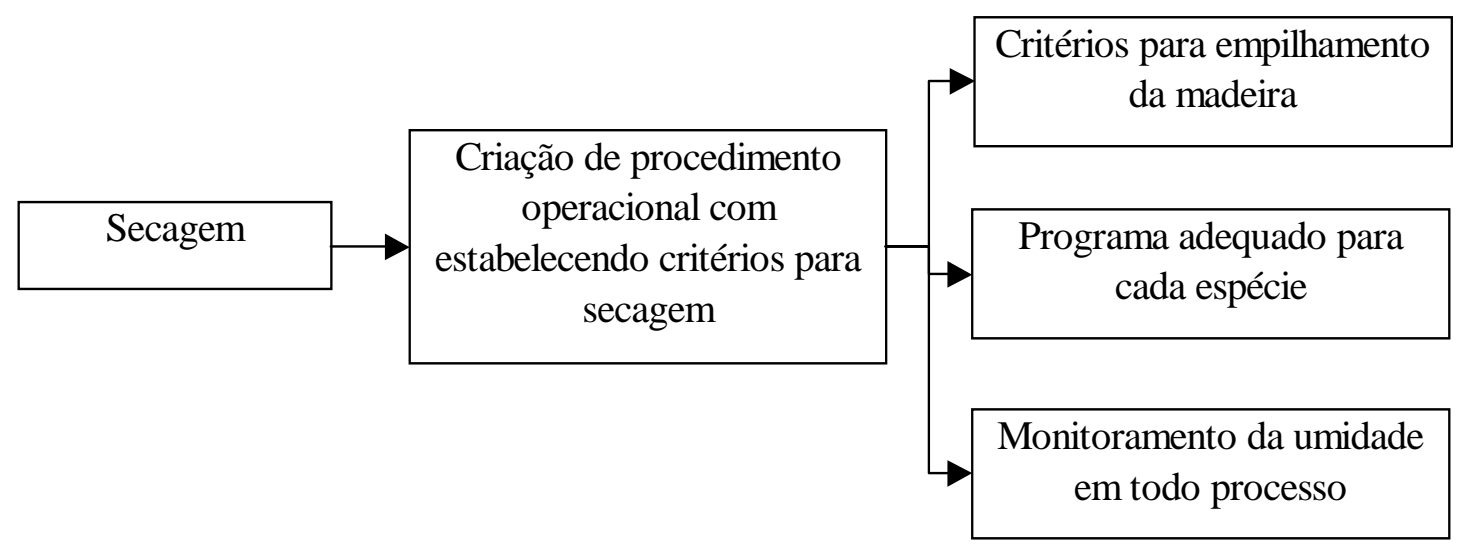

Figura 28 - Padronização da rotina para o processo de secagem

Um monitoramento da umidade após a secagem (umidade média/secagem) é fundamental para verificar se a secagem ocorreu ou não uniformemente.

\subsubsection{Pré -corte de batente e caixilho}

Os indicadores desta etapa do processo relacionados a madeira são o volume de sobras $\left(\mathrm{m}^{3}\right)$, aproveitamento $\left(\mathrm{m}^{3}\right)$, os defeitos da madeira e o descarte $\left(\mathrm{m}^{3}\right)$, em cada pedido. A Figura 29 ilustra os indicadores de desempenho sugeridos para este processo. 


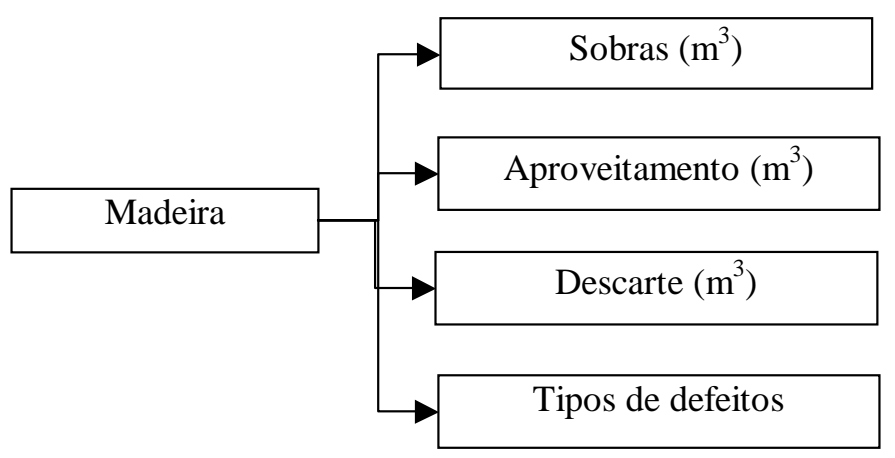

Figura 29 - Indicadores para avaliar o uso da madeira durante a atividade de pré corte

Para cada tipo de madeira utilizada no processo de fabricação de esquadrias os indicadores descritos na Figura 29, foram obtidos em oito pedidos com as espécies de freijó (Cordia goeldiana), cedro (Cedrella spp.) e tamarindo (Tamarindus indica). Os pedidos demoraram aproximadamente noventa dias para serem monitorados.

Para os pedidos que se utilizaram do freijó, foram aproveitados $87 \%$ da madeira utilizada diretamente na fabricação do pedido, $12 \%$ foram classificadas como sobra e lixo, e cerca de $8 \%$ foram classificadas como sobras passíveis de aproveitamento a longo prazo. A Figura 30 ilustra a madeira utilizada, quantidade descartada (lixo), sobras e o aproveitamento da madeira de freijó. 


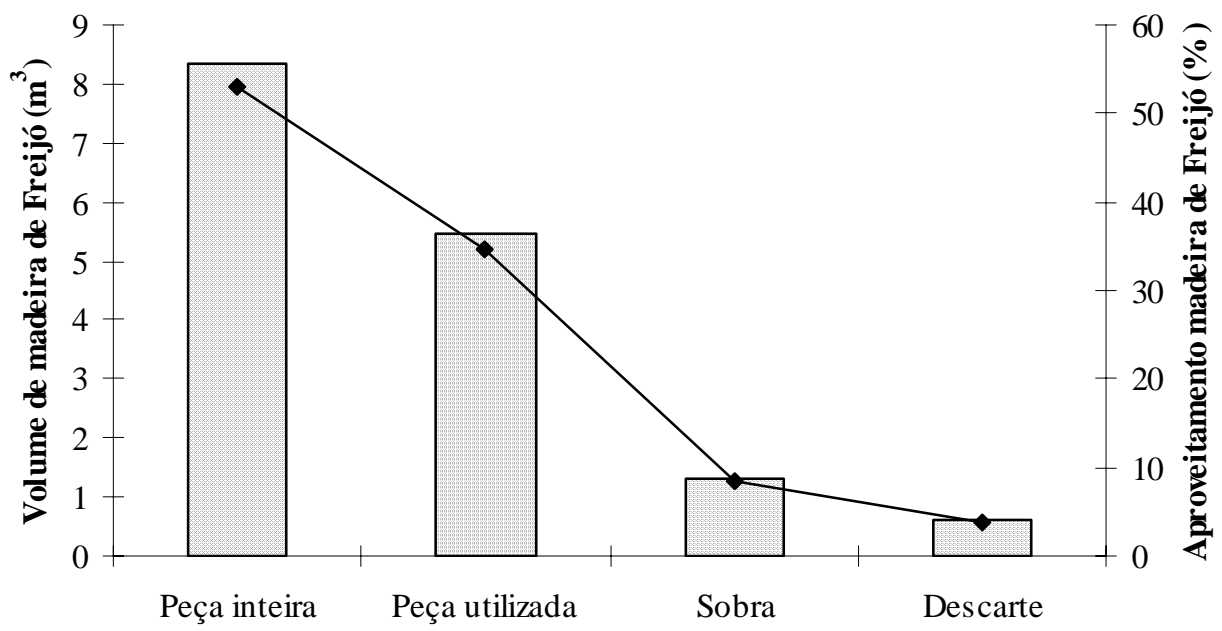

Figura - 30 Aproveitamento da madeira de freijó

A Figura 31 ilustra os principais motivos de descarte da madeira de freijó: rachaduras de topo e superficiais. Juntos os motivos somam $71 \%$, referentes a descarte da madeira e esse tipo de defeito está relacionado com a secagem.

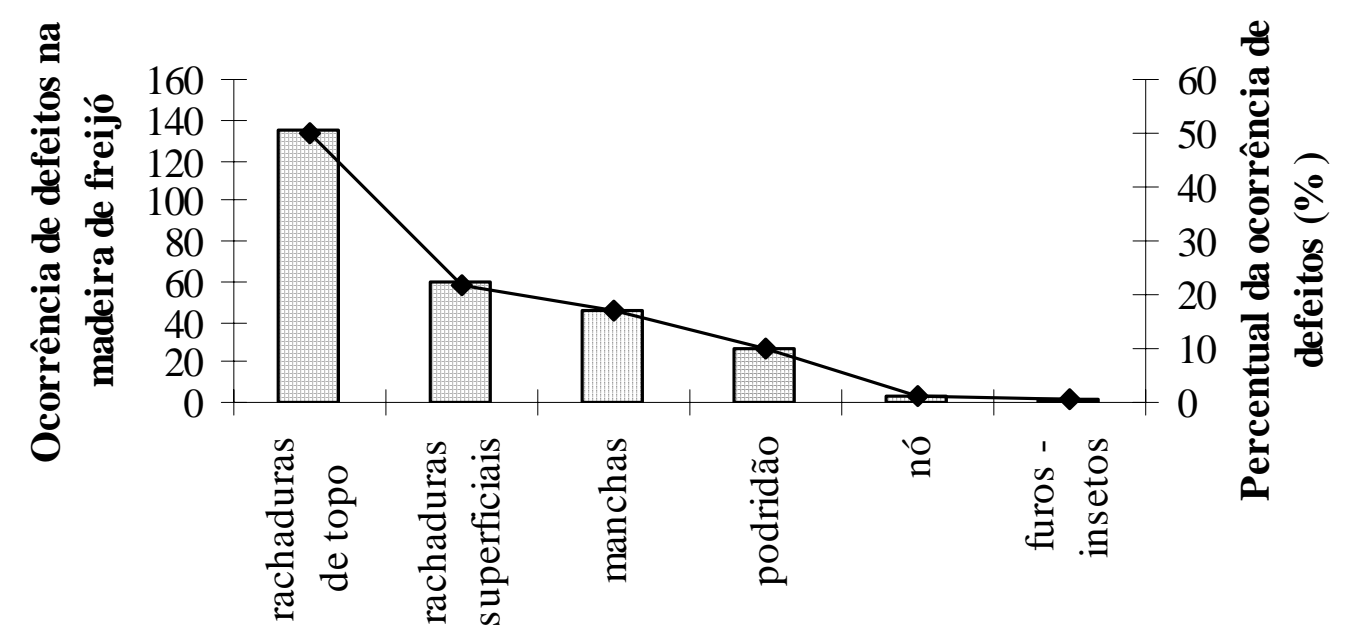

Figura 31 - Ocorrência de defeitos na madeira de freijó 
A Figura 32 ilustra o aproveitamento de madeira de cedro (Cedrella spp.), obtendo um aproveitamento similar ao freijó de 86\%. As sobras foram contabilizadas em $9 \%$ e o descarte em $4 \%$.

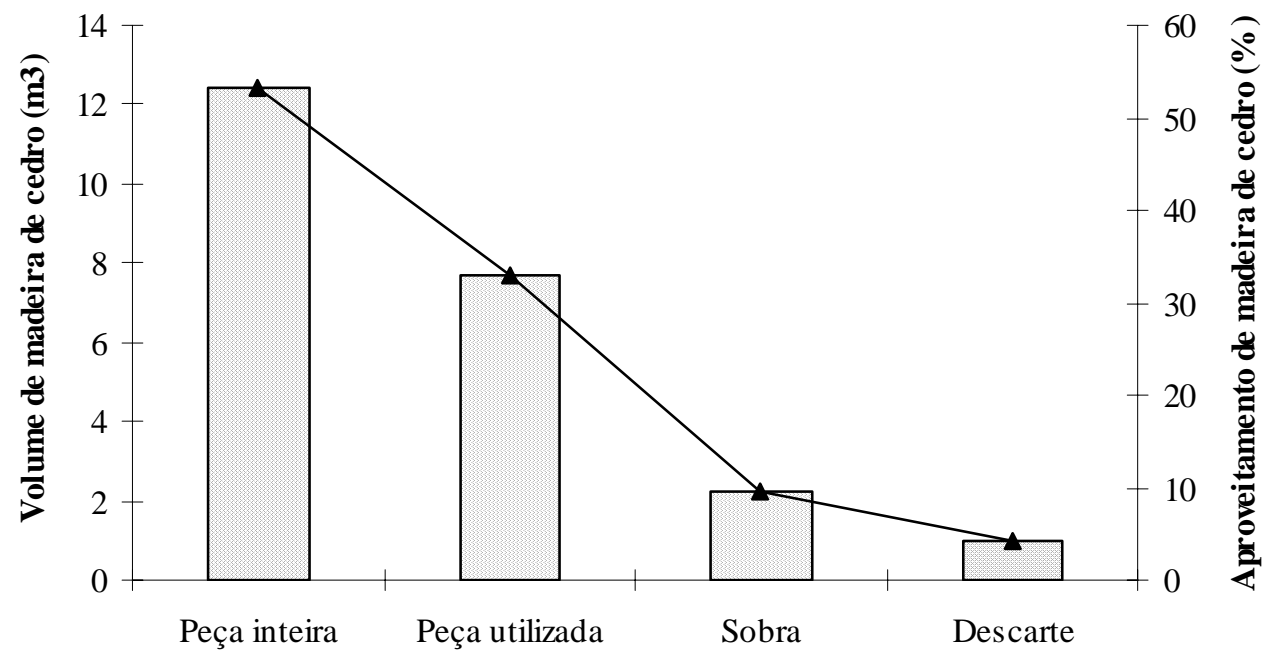

Figura 32 - Aproveitamento da madeira de cedro

A Figura 33 ilustra a ocorrência de defeitos da madeira de cedro sendo as principais classificadas como: manchas $27 \%$, rachaduras de topo $16 \%$ e grã reversa $16 \%$. 


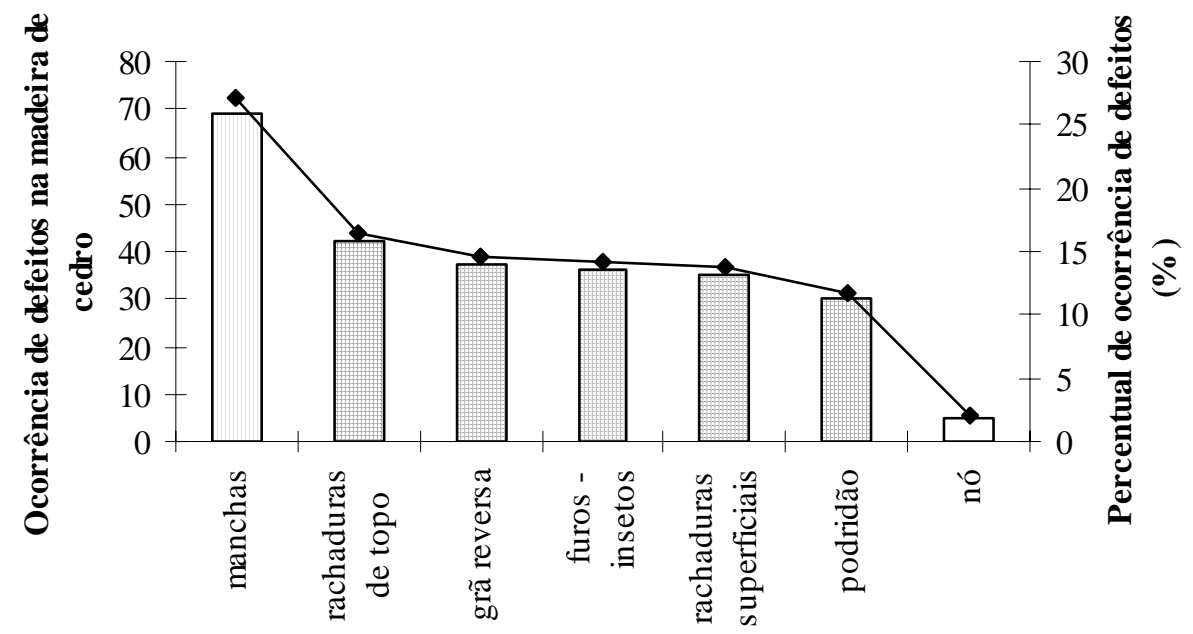

Figura 33 - Ocorrência de defeitos na madeira de cedro

Quanto aos pedidos que utilizaram da madeira de tamarindo eles obtiveram um aproveitamento de $90 \%$ das peças inteiras utilizadas, $9 \%$ sobraram e $3 \%$ foram descartadas. A Figura 34 ilustra graficamente esse aproveitamento.

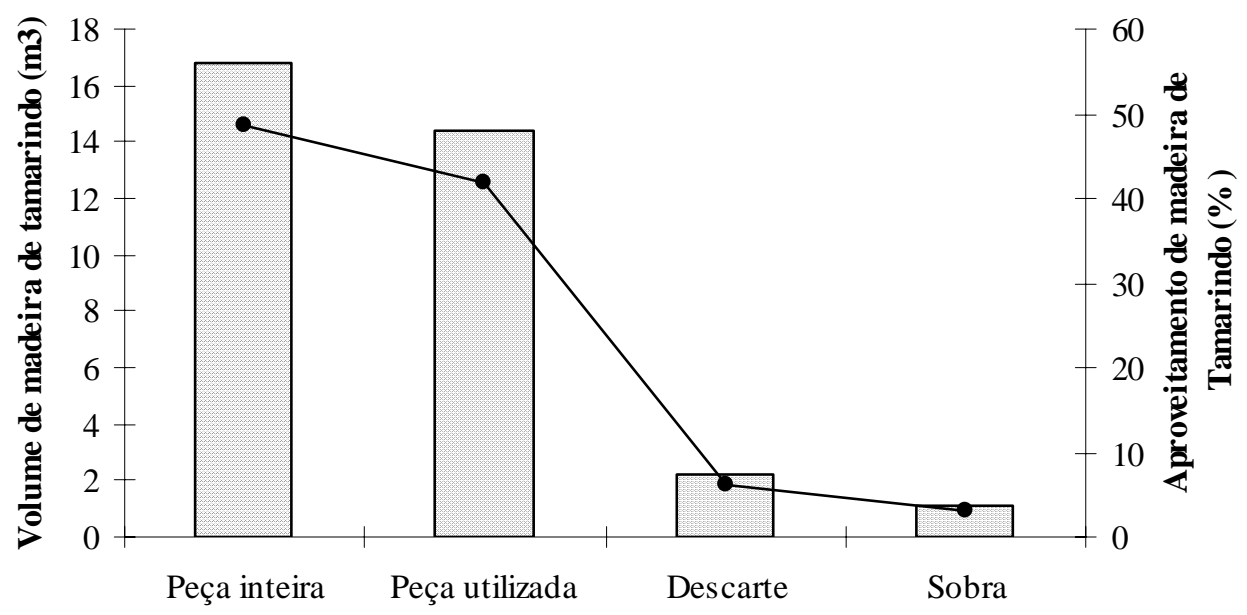

Figura 34 - Aproveitamento da madeira de tamarindo 
Os principais defeitos encontrados na madeira de tamarindo, ilustrados na Figura 35, são a presença de manchas na madeira (27\%), as rachaduras de topo (16\%) e grã reversa (14\%). Juntos estes defeitos representam 58\% dos motivos de descarte de madeira de tamarindo.

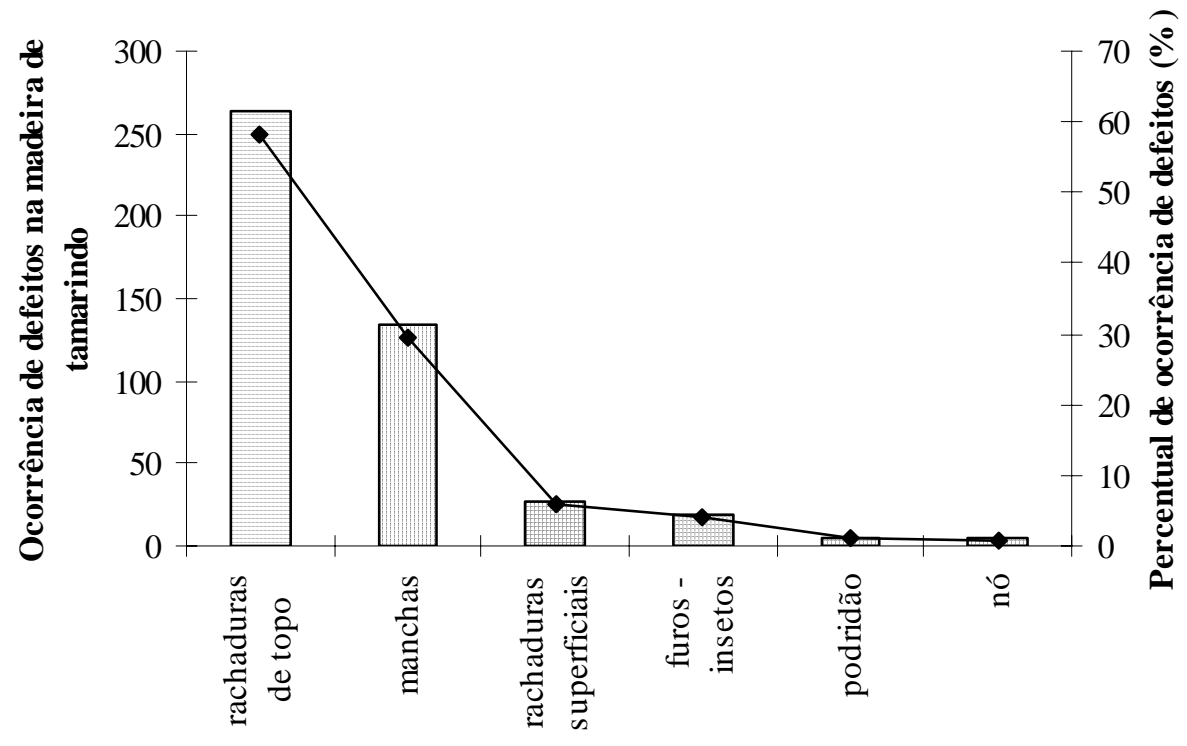

Figura 35 - Ocorrência de defeitos na madeira de tamarindo

\subsubsection{Beneficiamento}

Os principais itens críticos para esta atividade são os erros originados da falta de gerenciamento da rotina e treinamento da equipe. A Figura 36 apresenta uma sugestão para realizar o gerenciamento da rotina. 


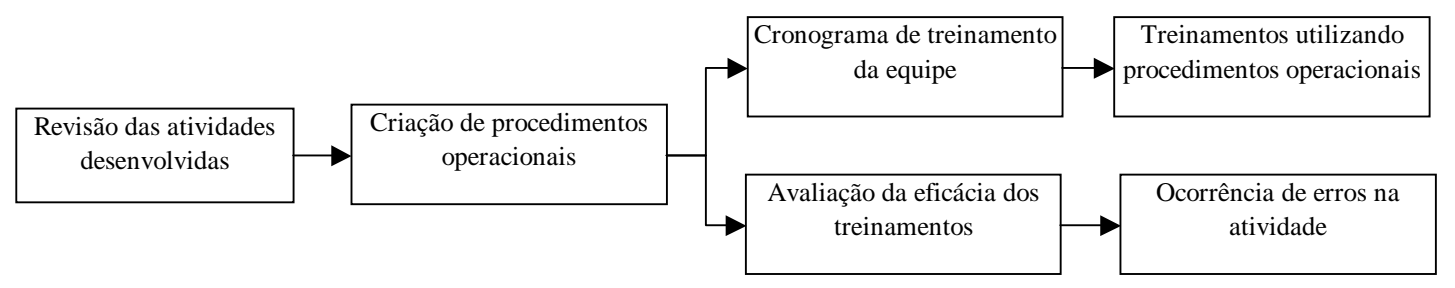

Figura 36 - Gerenciamento da rotina para a atividade de beneficiamento de madeira

A elaboração dos procedimentos operacionais deve contar com a presença de todas as pessoas envolvidas na atividade e o procedimento deve ser discutido e elaborado em equipe e não imposto. A participação da equipe visa garantir o envolvimento das pessoas para manter o procedimento atualizado e em uso constante.

\subsubsection{Pintura}

A atividade de pintura tem como principal problema a estrutura disponível para desenvolvimento do trabalho. A equipe que desempenha a atividade foi contratada recentemente e necessita de treinamento, não havendo preocupação com custos (gastos de materiais) e com a qualidade. O que existe é apenas a preocupação com a agilidade do processo, a Figura 37 ilustra a proposta de gerenciamento da rotina para a atividade. 


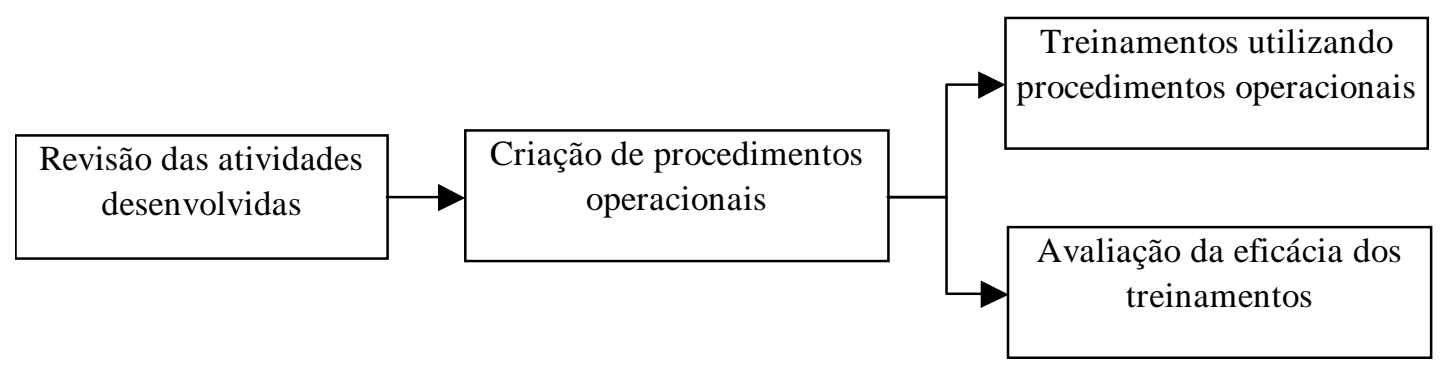

Figura 37 - Gerenciamento da rotina para a atividade de pintura

\subsubsection{Montagem}

Durante a atividade de montagem foi possível detectar as falhas que ocorrem e acabam passando desapercebidas ao longo do processo. O único item considerado crítico é a rachadura de batentes ocasionada no ato da montagem pela fixação de pregos. Os outros itens são problemas ocasionados em outras atividades. Levando-se em consideração que a atividade é a etapa final do processo, os indicadores desenvolvidos, descritos na Figura 38 são defeitos gerais da produção e retrabalho. O retrabalho é definido como o retorno de peças que foram entregues aos clientes e posteriormente foram devolvidas devido a constatação de defeitos. 


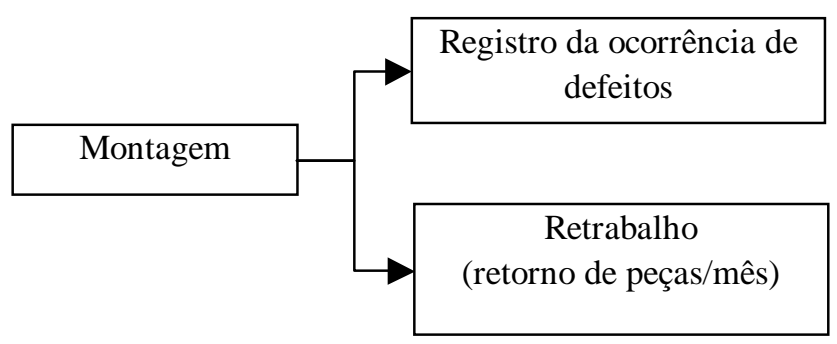

Figura 38 - Indicadores definidos para a montagem

A ocorrência de defeitos na produção foi registrada entre julho de 2002 e abril de 2003, sendo os principais problemas detectados pela montagem: presença de rachaduras nas peças; erros de projeto; e erros de regulagem de máquina.

A Figura 39 representa graficamente a freqüência de presença de rachaduras na madeira no processo produtivo. A ocorrência de rachaduras oscilou ao longo do período medido, que pode ser um reflexo da qualidade de secagem da madeira consumida pela fábrica. 


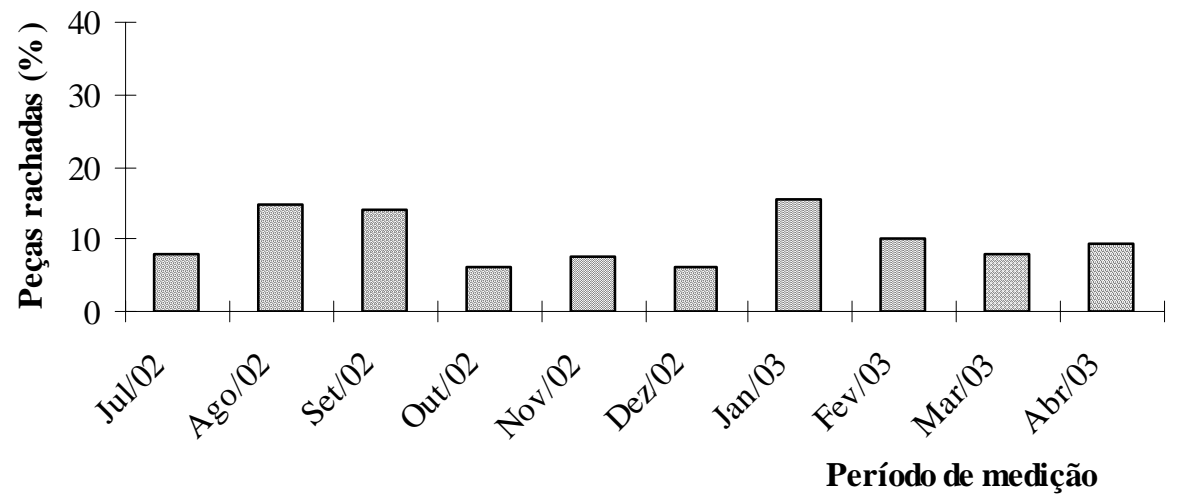

Figura 39 - Peças rachadas (junho de 2002 a abril de 2003)

A Figura 40 ilustra os erros de projeto e a Figura 41 os erros de operador. Os erros tem comportamento semelhante e foram sensivelmente reduzidos com gerenciamento da rotina, criação de procedimentos operacionais e treinamentos. 


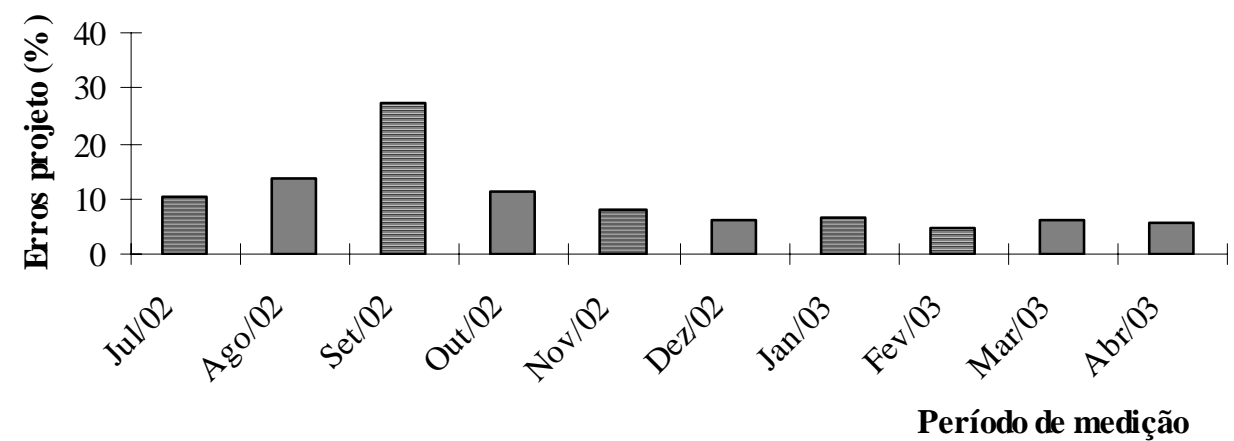

Figura 40 - Erros de projeto (junho de 2002 a abril de 2003)

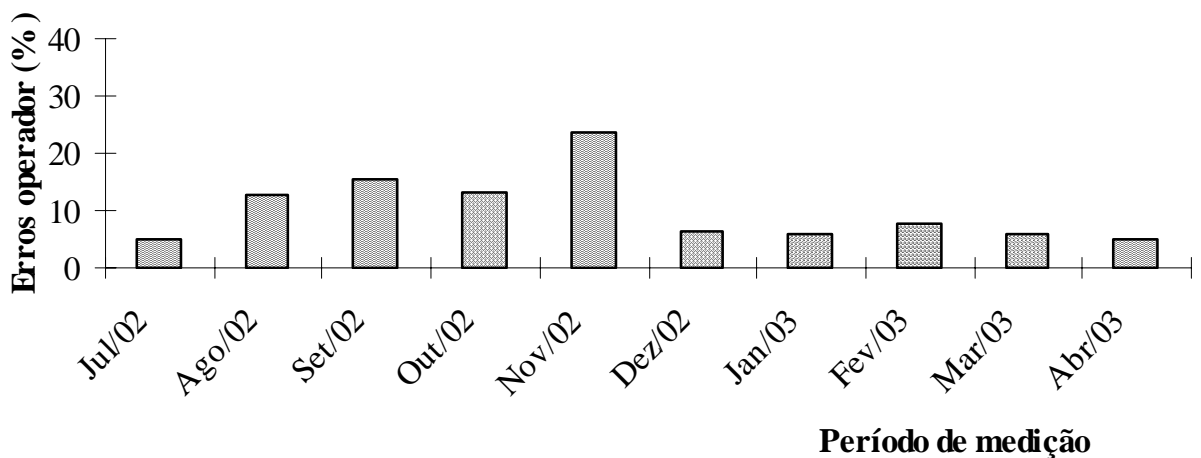

Figura 41 - Erros de operador (junho de 2002 a abril de 2003) 
A Figura 42 representa a freqüência de ocorrência dos erros de regulagem de máquina, que não apresentam nenhuma tendência a melhoria e não reflete nenhum efeito das medidas tomadas para melhoria deste item.

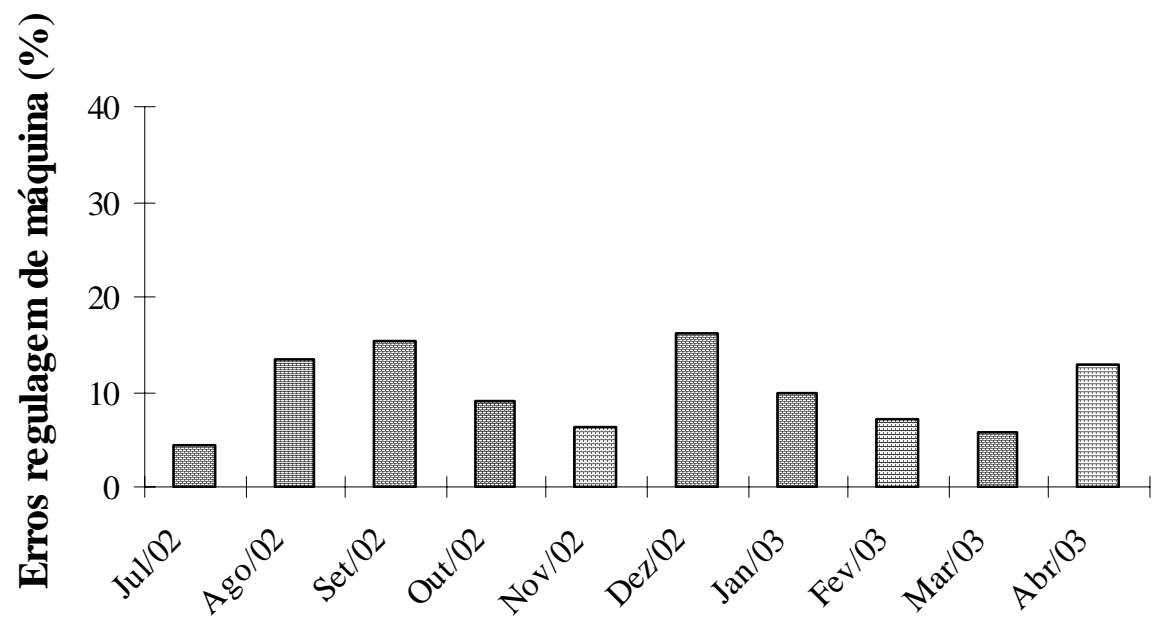

Período de medição

Figura 42 - Erros de regulagem de máquina (junho de 2002 a abril de 2003)

A partir do monitoramento da ocorrência de defeitos é possível implantar as ações corretivas (procedimentos operacionais, treinamentos e desenvolvimento de novas tecnologias) para que esses itens não tornem a acontecer, pois causam prejuízos (geram custos) e atrasos na produção.

O indicador de desempenho de retrabalho (retorno de peças por mês), foi coletado durante o período de janeiro de 2002 a dezembro de 2003. As Figuras 43 e 44 ilustram o retrabalho no período analisado. 


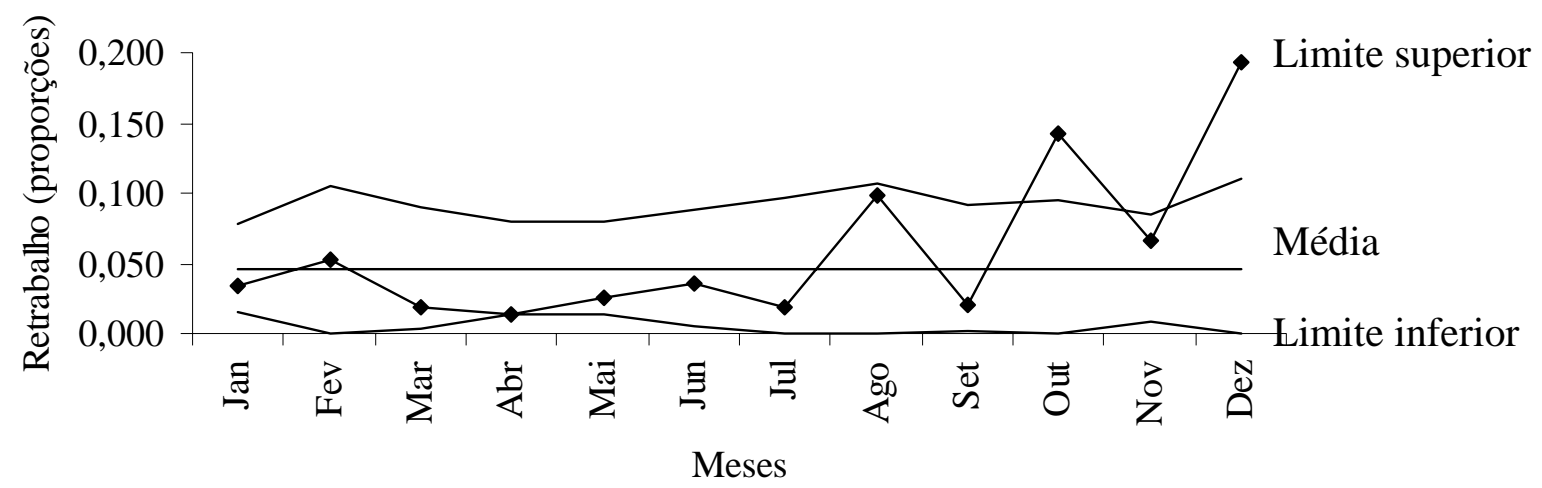

Figura 43 - Retrabalho de janeiro a dezembro de 2002

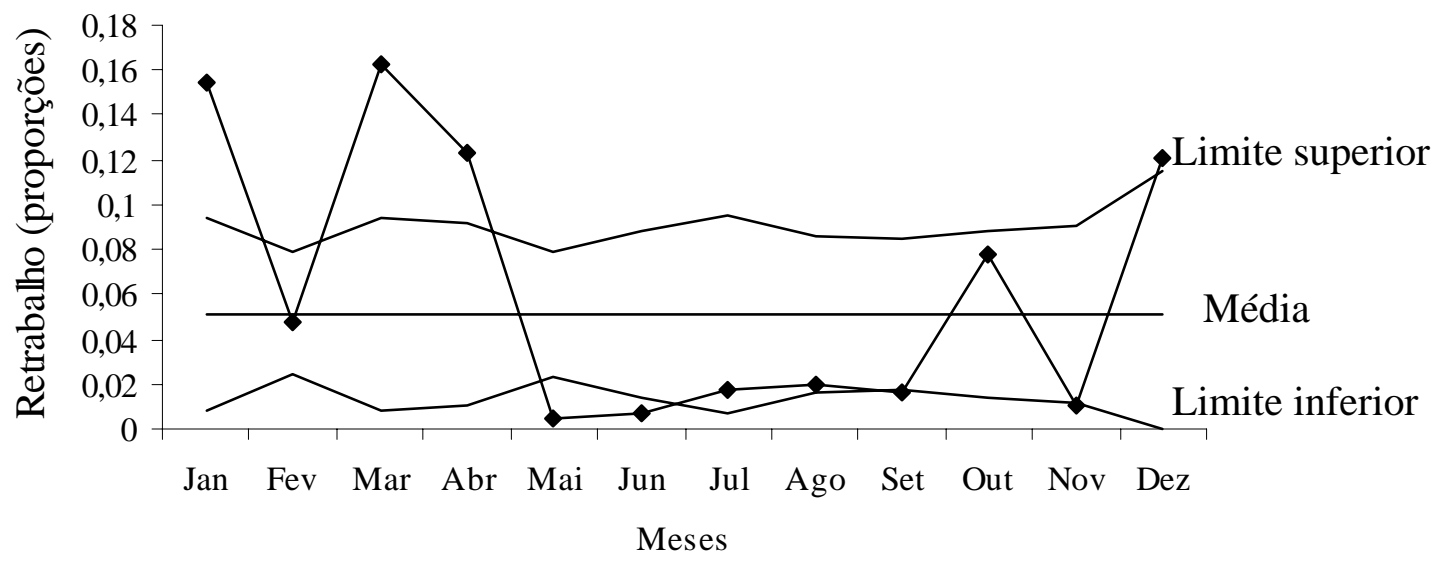

Figura 44 - Retrabalho de janeiro a dezembro de 2003 
De acordo com as Figuras 43 e 44 o processo encontra-se fora de controle, ilustrado pela oscilação dos “picos”. Esse comportamento pode ser caracterizado pela falta de gerenciamento da rotina. Nos dois anos analisados, o período de setembro a dezembro é caracterizado por aumento dos retrabalhos, isso pode ocorrer pelo aumento na demanda de entrega de produtos. Geralmente nesse período os clientes pedem que a entrega seja antecipada visando as festas de final de ano.

\subsubsection{Projetos}

Para atividade de projeto seria ideal uma revisão das atividades, com o envolvimento da equipe, que se mostra pouco preparada e pouco comprometida para o planejamento da rotina e para o desenvolvimento de melhoria. 


\section{CONCLUSÕES}

A metodologia proposta possibilitou o desenvolvimento de indicadores de desempenho referentes às etapas do processo de produção da empresa. Os indicadores fornecem as informações que possibilitam o gerenciamento da rotina e monitoram as oportunidades de melhoria das atividades desenvolvidas na produção.

A empresa analisada, de um modo geral, apresenta uma rotina não definida e fora de controle. Os indicadores de desempenho desenvolvidos atuam como fonte de informações durante o processo de tomada de decisões operacionais, táticas e estratégicas (gerenciamento com base em fatos e dados).

Os principais pontos de melhoria identificados são: análise do fornecedor de madeira, controle de estoque, controle de perdas de madeira, qualidade da madeira pós secagem, controle da utilização da madeira (sobras, aproveitamento, descarte), gerenciamento da rotina com criação e implantação de procedimentos operacionais e treinamento dos funcionários nesses procedimentos, incidência de retrabalhos e defeitos na montagem de peças 


\section{REFERÊNCIAS BIBLIOGRÁFICAS}

\section{ASSOCIAÇÃO BRASILEIRA DA INDÚSTRIA DE MADEIRA PROCESSADA}

MECANICAMENTE. Madeira Processada mecanicamente: estudo setorial 2001 32p. http://www.abimci.com.br. (23 dez. 2003).

ASSOCIAÇÃO BRASILEIRA DA INDÚSTRIA DE MADEIRA PROCESSADA MECANICAMENTE. O setor florestal e o segmento de madeira sólida no Brasil. Relatório encaminhado ao fórum nacional das atividades de base florestal. Brasília. mai 2003 12p. http://www.abimci.com.br/port/06Doc/0601DocCNI0503/0601 FrameSet.html. (15 abr. 2004).

ANDRADE,A. Indicação de programas para secagem convencional de madeiras. Piracicaba, 2000. 85p. Dissertação (Mestrado.) - Escola Superior de Agricultura “Luiz de Queiroz”, Universidade de São Paulo.

ANDRIANI, C.S. UGB: Unidade gerencial básica (Compact Disc). Campinas: Diagrama Consultoria, 2002. 
ANDRIANI, C.S. Gestão sistêmica com base em valores humanos. São Paulo, 2003. 159p. Dissertação (Mestrado) - Universidade Capital.

ASSOCIAÇÃO BRASILEIRA DE NORMAS TÉCNICAS. Sistemas de gestão da qualidade: fundamentos e vocabulário. Rio de Janeiro: ABNT, 2000. 32p.

BEUREN, I.M. Gerenciamento da informação: um recurso estratégico no processo de gestão empresarial. 2. ed. São Paulo: Atlas, 2000. 120p.

BITITCI, U.M.; CARRIE, A.S.; McDEVITT,L. Integrated performance measurement systems: an audit and development guide. The TQM Magazine, v.9, n.1, p.46-53, 1997.

BANCO NACIONAL DE DESENVOLVIMENTO ECONÔMICO E SOCIAL; 2003. Micro, pequenas e médias empresas. http://www.bndes.gov.br/pme/default.asp. (31 jan. 2003).

BANCO NACIONAL DE DESENVOLVIMENTO ECONÔMICO E SOCIAL; 2004 Classificação de porte das empresas. http://www.bndes.gov.br/clientes/porte/ porte.asp. (30 abr. 2004).

CASSARRO, A C. Sistemas de informações para tomada de decisões. 3. ed. São Paulo: Pioneira, 1999.130p. 
CAMPOS, V.F. TQC: Controle de qualidade total (no estilo japonês). Belo Horizonte, MG: Fundação Christiano Ottoni, Escola de Engenharia da UFMG, 1992. 229p.

CROSS, K. F.; LYNCH, R.L. Managing the corporate warriors. Quality Progress, v.23, n. 4, p.54- 59, Apr. 1990.

DELLARETTI FILHO, O. As sete ferramentas do planejamento da qualidade. Belo Horizonte: Fundação Christino Ottoni, 1996. 183p.

DELLARETTI FILHO, O.; DRUMOND, F.B. Itens de controle e avaliação de processos. Belo Horizonte: Fundação Christino Ottoni, 1994. 151p.

FMECA.COM. Fmea history. http://www.fmeca.com/ffmethod/history.htm. (18 dec. 2003).

GARVIN, D.A. Managing quality: the strategic and competitive edge. NEW YORK: Free Press, 1988. 358p.

HELMAN, H.; ANDERY, P.R.P. Análise de falhas: aplicação dos métodos de FMEA e FTA. Belo Horizonte: Fundação Christino Ottoni, 1995. 156p. 
HOLLOWAY, J. Investing the impact of performance measurement. International Journal Business Performance Management, v.3, n.2/4, p.167 - 180, Oct.2001.

HCI Consulting, 2004 PDCA Cycle: From problem - faced to problem-solved. http:www.hci.com.au/hcisite2/toolkit/pdcacycl.htm. (31 jan.2004).

JUVENAL,T.L.; MATTOS,R.L.G. O setor florestal no Brasil e a importância do Reflorestamento. BNDES Setorial, n.16, p.3 - 30, set 2002. http://www.bndes.gov.br/conhecimento/bnset/set1601.pdf. (28 abr. 2004).

KAYDOS, W. Performance measurement and performance management. Measuring, managing and maximizing performance. Portland:Productivity Press, 1991. cap 3, p.33-51.

KIYAN, F. M. Proposta para desenvolvimento de indicadores de desempenho como suporte estratégico, São Carlos, 2001. 108p. Dissertação (Mestrado) - Escola de Engenharia de São Carlos, Universidade de São Paulo.

LAUDON, K.C.; LAUDON, J.P. Management information systems: Organization and technology. 3. ed. Basingstoke: Macmillan , 1994. 820 p.

LEBAS, M.J. Performance measurement and performance management. International Journal of Production Economics, n. 41, p.23-35, 1995. 
MACEDO-SOARES,T.D.L.V.A.; RATTON,C.A. Medição de desempenho e estratégias orientadas para o cliente: resultados de uma pesquisa de empresas líderes no Brasil. Revista de Administração de Empresas, v.39, n.4, p.46-59, Out./Dez. 1999.

MERLI, G. Eurochallenge: the tqm approach to capturing global markets. Oxford: Information Press, 1993. 208p.

MONTGOMERY, D.C. Introduction to statistical quality control. New York: John Wiley, 1985. 489p.

MINISTÉRIO DO MEIO AMBIENTE; 2002 Apresentação do programa nacional de florestas (PNF). http://www.mma.gov.br/cgmi/institu/pesquisas/index.cfm. (17 mar 2004).

NAHUZ, M. Mercado internacional sinaliza evolução. Revista da madeira, v. 14, n.80, p.12-16, Abr. 2004.

NEELY, A. Why measure? Measuring business performance, London: The Economist, 1998. 150p. 
OLIVEIRA, J.T da S. Cresce presença do setor de base florestal. Revista da Madeira, v. 10, n. 56, p.14-22, Mai. 2001.

PONGELUPPE, P.C. Modelo de indicadores de desempenho para micro e pequena agroindústria: multi-caso de laticínios. São Carlos, 2002. 169p. Dissertação (Mestrado) - Universidade Federal de São Carlos.

REMADE; 2004. Série histórica da produção de serrados no Brasil. http://www.remade.com.br/banco_dados/madeira/4.php. (15 mar. 2004).

REVISTA DA MADEIRA Setor bate recorde e exporta US\$ 4,5 bilhões. Revista da Madeira. v.9, n. 54, p.4-6, Set. 2001.

RUTTLEDGE, P. Failure mode and effect analysis (FMEA). http://pbma.hq.nasa.gov/mainframe_docs/video/trans_1_2/peter45.doc. $\quad$ (20 jun. 2004).

SARRIÉS, G A. Controle estatístico da qualidade para impurezas minerais em carregamentos de cana-de-açúcar. Piracicaba, 1997. 88p. Tese (Doutorado) - Centro de Energia Nuclear na Agricultura, Universidade de São Paulo.

SARRIÉS, G.A.; LAI REYES, A.E.; VICINO, S.R. Qualidade total: diagrama de causa e efeito. http://www.esalq.usp.br/qualidade. (15 mar. 2004). 
SLACK, N.; CHAMBERS, S.; HARLAND, C.; HARRISON, A.; JOHNSTON, R. Administração da produção: edição compacta. Trad. de A.B.Brandão, C.D. Straube, H. Corrêa, S. Corrêa e I. Gianesi. São Paulo: Atlas, 1999. 526p.

SHIBA, S.; GRAHAN, A.; WALDEN, D.; ASAY, D. A new American TQM: four practical revolutions in management. Portland: Produtivity Press, 1993. cap. 1, p.3 14: The evolution of the quality concept.

STAMATIS, D.H. Failure mode and effect analysis: FMEA from theory to execution. Wisconsin: ASQ Quality Press, 1995. 494p.

TENG, S.H.G.; HO, S. Y.M. Failure mode and effect analysis: an integrated approach for product design and process control. International Journal of Quality \& Reliability Management, v. 13, n.5, p.8-26, Fev. 1996.

VIEIRA, S. Estatística para a qualidade: como avaliar com precisão a qualidade em produtos e serviços. Rio de Janeiro: Campus, 1999. 198p.

WANG, H. Statistical quality control. http://www.stat.colostate.edu/ jah/teach/st204/ notes/L14.2and16.pdf. (15 jul. 2004). 